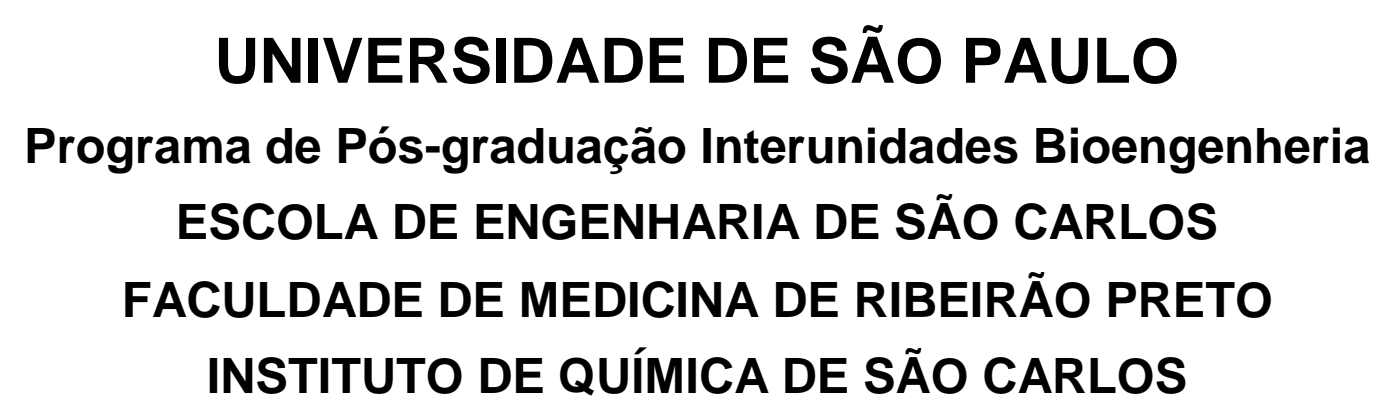

MAURICIO BORDINI DO AMARAL

\title{
CAPACIDADE DE REGENERAÇÃO ÓSSEA DE BIOMATERIAIS EM DEFEITO CRÍTICO DE CALVÁRIA: ANÁLISE HISTOLÓGICA E MICROTOMOGRAFIA COMPUTADORIZADA
}

SÃO CARLOS 


\section{CAPACIDADE DE REGENERAÇÃO ÓSSEA DE BIOMATERIAIS EM DEFEITO CRÍTICO DE CALVÁRIA: ANÁLISE HISTOLÓGICA E MICROTOMOGRAFIA COMPUTADORIZADA}

Tese de doutorado apresentada ao Programa de Pós-Graduação Interunidades Bioengenharia Escola de Engenharia de São Carlos / Faculdade de Medicina de Ribeirão Preto / Instituto de Química de São Carlos da Universidade de São Paulo como parte dos requisitos para a obtenção do título de doutor em Ciências.

Área de Concentração: Bioengenharia

Orientadora: Prof ${ }^{a}$. Dr ${ }^{\mathrm{a}}$. Ana Maria de Guzzi Plepis

São Carlos 


\section{MAURICIO BORDINI DO AMARAL}

Titulo: "Capacidade osteocondutora de biomateriais em defeito crítico de calvária: Análise histológica e microtomografia computadorizada".

$$
\begin{aligned}
& \text { TESE APRESENTADA AO PROGRAMA DE PÓS-GRADUACCÃO } \\
& \text { INTERUNIDADES BIOENGENHARIA EESC/FMRPIIQSC DA UNIVERSIDADE } \\
& \text { DE SÃO PAULO PARA OBTENÇÃO DO TITULO DE DOUTOR EM CIÊNCIAS } \\
& \text { NA ÁREA DE BIOENGENHARIA. }
\end{aligned}
$$

Aprovado em: 01103,2013

Profa. Dra . Ana Niaria de Guzzi Plepis (ORIENTADORA)

Resultado: aprovodo

Prof. Dr. Rodrigo Cardoso de Oliveira

Resultado: APROVADO

Prof. Dr. Sergio Kiyoshi Ishikiriama

Resultado: ApRovaDo

Prof. Dr. Sergio Britto Garcia

Resultado: APROVADO
Instituto de Química de São Carlos - USP

Assinatura: Ana Mavia splejus

Faculdade de Odontologia de Bauru - USP

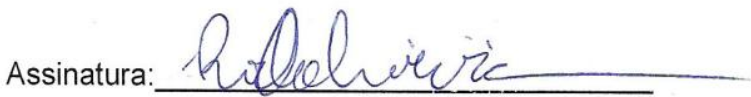

Faculdade de Odontologia de Bauru - USP

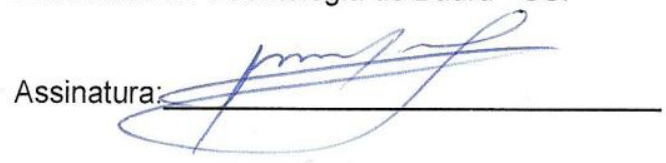

Faculdade de Medicina de,Ribeirão Preto - USP

Assinatura:

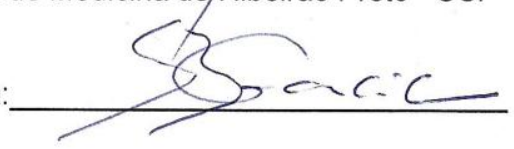

Escola de Engenharia de São Carifos - USP

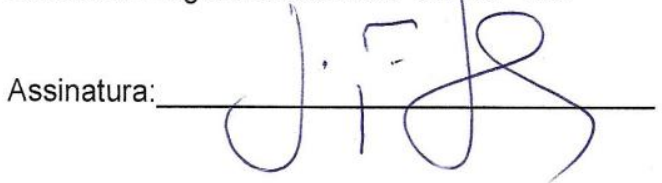




\section{DEDICATÓRIA}

Dedico em primeiro lugar este trabalho à minha querida esposa Aline, que sempre me apoiou estando junto de mim nessa jornada dando-me valorosos conselhos que enriqueceram minha obra.

Também gostaria de dedicar essa tese aos meus sempre presentes pais, Vera e Joaquim, os quais estiveram sempre ao meu lado em todas as fases da vida, dando-me sensatos e sábios ensinamentos que me guiaram na direção da bondade, da retidão, da fé, da perseverança e do sucesso.

Finalmente, gostaria de lembrar que o motivo principal desse estudo é dar um pequeno incremento no avanço da ciência da regeneração tecidual $e$, fundamentalmente, na melhoria da qualidade de vida de todos os pacientes, em especial, aqueles que me acompanham na rotina diária da clínica odontológica. 


\section{AGRADECIMENTOS}

Agradeço em primeiro lugar à Deus que me deu força, saúde e paz para conduzir esse trabalho da maneira mais prazerosa possível.

Agradeço a minha sábia orientadora Prof ${ }^{\mathrm{a}}$. Ana Maria de Guzzi Plepis, a qual além de me guiar na execução do trabalho também me deu preciosos conselhos de vida.

A Universidade de São Paulo que desde a graduação, passando pela residência, o mestrado e agora o doutorado, fomentou meus estudos, formando um profissional apto a solucionar os problemas diários e colaborar para o avanço da sociedade.

Ao Programa de Pós-graduação Interunidades em Bioengenharia da Universidade de São Paulo que me deu a oportunidade de desenvolver um trabalho com a interação de diferentes disciplinas, mostrando os problemas de uma forma plural.

Ao laboratório de Bioquímica e Biomateriais do Instituto de Química de São Carlos - USP, sob supervisão da Dra. Virgínia Conceição Amaro Martins, a qual me ajudou bastante na execução do trabalho.

Ao laboratório e biotério da Bioengenharia da Escola de Engenharia de São Carlos - USP, aos cuidados do MSc Nelson Ferreira da Silva Júnior, o qual me ajudou muito nas cirurgias e no tratamento dos animais.

As secretarias de Pós-graduação da Bioengenharia Janete e Nathalia.

Ao aluno de doutorado Alessandro Hakme pela ajuda na análise de microtomografia computadorizada. 
A Profa. Vanda Jorgete do Hospital das Clínicas da Universidade de São Paulo pela ajuda na análise histológica.

Ao CNPDIA da Embrapa Instrumentação de São Carlos e aos pesquisadores responsáveis Dr. Carlos Manoel Pedro Vaz, Dr. Luiz Francisco Mattêo Ferraz, Dr. Paulo Renato Orlandi Lasso e Dr. Álvaro Macedo da Silva.

Ao Laboratório de Morfologia da Faculdade de Odontologia de Araraquara UNESP e ao técnico responsável Pedrinho.

Aos funcionários da biblioteca do EESC, em especial a Juliana que me ajudou na formatação da tese.

Aos meus queridos irmãos Américo e Ricardo, os quais, desde a infância, cresceram e protegeram-me transmitindo muita segurança.

As minhas cunhadas Muriel, Tatiana, Anali e meus cunhados Eduardo e Caio pelos bons momentos que passamos juntos.

Aos meus sempre alegres e espertos sobrinhos Matheus, Isabella Bassi, Isabella Tabox e Alice pela esperança renovada a cada encontro.

A todos os professores, profissionais, amigos e parentes que colaboraram de qualquer maneira na minha formação e na execução do trabalho.

Muito obrigado a todos. 
"Lembremo-nos de que o homem interior se renova sempre. A luta enriquece-o de experiência, a dor aprimora-lhe as emoções e o sacrifício tempera-lhe o caráter. O espirito sofre constantes transformaçôes por fora, a fim de purificar-se e engrandecer-se por dentro." 


\section{RESUMO}

AMARAL, M. B. (2013). Capacidade de regeneração óssea de biomateriais em defeito crítico de calvária: análise histológica e microtomografia computadorizada. 110f. Tese (Doutorado) - Escola de Engenharia de São Carlos/ Instituto de Química de São Carlos/ Faculdade de Medicina de Ribeirão Preto, Universidade de São Paulo, São Carlos, 2013.

O elevado número de cirurgias de enxertia óssea impulsiona o desenvolvimento de novos biomateriais de preenchimento. Materiais a base de hidroxiapatita sintética e tendão bovino mineralizado foram preparados para servirem de arcabouço para regeneração óssea. Este estudo teve como objetivo avaliar a osteocondutibilidade desses materiais, comparando-os ao Bio-Oss/ Geistlich. Foram criados defeitos de tamanho crítico (circular / $8 \mathrm{~mm}$ ) na calvária de ratos Wistar, preenchidos com os biomateriais e, após 30 dias, ocorreu o sacrifício, análise não invasiva por microtomografia computadorizada (micro-CT/ microtomógrafo SkyScan $100 \mathrm{kV}-100 \mu \mathrm{A}$ ) com reconstituição de imagem em três dimensões (3D) e análise histológica convencional para avaliar a neoformação óssea e comparar os métodos. Os resultados da micro-CT mostraram que o BioOss apresentou maior volume, densidade e porcentagem de tecido ósseo que os demais grupos. Nas imagens reconstituídas em 3D notou-se no grupo Bio-Oss as menores taxas de reabsorção, permanecendo em maior quantidade no interior do defeito aos trinta dias. No grupo da hidroxiapatita sintética notou-se uma intensa reabsorção do material e uma leve neoformação óssea nas margens do defeito, deixando-o com um contorno irregular. $O$ grupo do tendão bovino mineralizado apresentou discretíssima neoformação óssea e o material foi totalmente reabsorvido. Já na avaliação da presença do material, de vasos sanguíneos e das células osteoblásticas no interior do defeito obtidos através da análise histológica, os grupos Bio-Oss e hidroxiapatita sintética obtiveram resultados semelhantes e maiores que o tendão bovino mineralizado. Constatou-se através da análise histológica que a hidroxiapatita sintética mostrou-se presente no interior do defeito exibindo propriedades osteocondutoras semelhantes a marca comercial Bio-Oss. Já o tendão bovino mineralizado não teve boa osteocondução, sendo contra-indicado na manutenção do espaço ósseo. Na comparação dos dois métodos, constatou-se que a micro-CT apresenta baixa especificidade, ou seja, não foi capaz de distinguir o tecido ósseo do Bio-Oss e alta sensibilidade, pois quantifica de uma forma muito precisa os valores com alta resolução. Já a análise histológica consegue distinguir com precisão os materiais e o tecido adjacente, porém não consegue quantificá-los de maneira fácil e precisa. Portanto, conclui-se que a hidroxiapatita sintética tem grande potencial de ser utilizada no preenchimento de defeitos ósseos, diferentemente do tendão bovino mineralizado. Quanto aos métodos de avaliação, eles são complementares e novos aprimoramentos devem ser feitos na técnica de micro-CT para melhorar sua capacidade de distinguir diferentes materiais.

Palavras-chave: Biomateriais. Enxerto ósseo. Hidroxiapatita. Defeito crítico calvária rato. Microtomografia computadorizada. 


\begin{abstract}
AMARAL, M. B. (2013). Bone regeneration in critical-size defects using hydroxyapatite, mineralized bovine tendon and Bio Oss: a three-dimensional micro-computed tomographic and histological study. 110f. Tese (Doutorado) - Escola de Engenharia de São Carlos/ Instituto de Química de São Carlos/ Faculdade de Medicina de Ribeirão Preto, Universidade de São Paulo, São Carlos, 2013.
\end{abstract}

Biodegradable bone grafts have been widely employed on bone regeneration. The purpose of this study was to evaluate the osteoconductive potential of hydroxyapatite, mineralized bovine tendon and Bio-Oss/Geistlich in a rat critical-size calvaria defect model through non-destructive three-dimensional (3D) microtomographic $(\mu \mathrm{CT})$ imaging and histological evaluation. Two experimental biomaterials were developed: synthetic hydroxyapatite (particles size $<0,2 \mathrm{~mm}$ ) and mineralized bovine tendon. Bio-Oss/Geistlich was employed as a control group. A critical size defect $(8 \mathrm{~mm})$ was created in the skull of Wistar rats (weight $200-300 \mathrm{~g}$ ) and treated with the biomaterials and one group was left untreated in the control group $(n=5)$. After 30 days, the animals were killed and the calvaria removed for $\mu C T$ and histological analysis. No adverse reactions were noted. No bone repair was observed in untreated surgical defects. The results of micro-CT showed that BioOss showed higher volume, density and percentage of bone tissue than the other groups. In the images reconstructed in 3-D was noted in the group Bio-Oss the lowest rates of resorption, staying in larger quantities within thirty days of the defect. In the group of synthetic hydroxyapatite noticed an intense resorption of the material and a slight bone formation at the margins of the defect, leaving him with an irregular contour. The bovine tendon mineralized group presented discreet bone formation and the material was completely resorbed. In the evaluation of the presence of the material, blood vessels and osteoblastic cells within the defect obtained by histological analysis, the groups Bio-Oss and synthetic hydroxyapatite showed similar results and larger than the mineralized bovine tendon. We verified by histological analysis that the synthetic hydroxyapatite is present within the defect displaying osteoconductive properties similar to trademark BioOss. Already the mineralized bovine tendon, again, did not have good osteoconduction and is contraindicated in maintaining the bone. When comparing the two methods observed that the micro-CT has low specificity, ie, was not able to distinguish the bone tissue to Bio-Oss and high sensitivity, as quantified in a very accurate values with high resolution. Already histological analysis can accurately distinguish materials and tissues, but can not quantify them easily and accurately. Therefore, we conclude that the synthetic hydroxyapatite has great potential to be used to fill bone defects, unlike mineralized bovine tendon. When comparing the methods, we found that still are complementary and new enhancements must be made in micro-CT technique to improve their ability to distinguish different materials.

Keywords: Biomaterial. Hydroxyapatite. Calvaria critical size defect. Bone regeneration. Micro-computed tomography $(\mu-C T)$. 


\section{LISTA DE FIGURAS}

Figura 1 - Imagens do reparo ósseo de um material de substituição óssea. (D) corte histológico evidenciando a interação do material com as células do hospedeiro e os vasos sanguíneos. (E) reconstituição em três-dimensões do material e os vasos sanguíneos obtidos através da nano-CT.

Figura 2 - Técnica cirúrgica de enxertia com BioOss na maxila anterior. (A) extração do incisivo central superior exibindo perda óssea importante, o que inviabilizaria a colocação do implante de titânio; (B) osso bovino inorgânico compactado no interior do alvéolo ocupando todo o espaço anteriormente ocupado pela raiz dentária; (C) colocação de membrana de colágeno bovino e sutura; (D) aspecto do tecido ósseo reparado com volume satisfatório na cirurgia de reabertura quatro meses após para colocação do implante e $(E)$ instalação do implante. Resultado final com instalação de coroa protética estética 28

Figura 3 - Microscopia eletrônica de varredura do compósito de fosfato de cálcio e fibras colágenas bovinas: (a) fibras colágenas ainda aderidas as partes separadas por ensaio de compressão; (b) fibras colágenas entremeadas na matriz do cimento de fosfato de cálcio; (c) partículas de hidroxiapatita precipitadas na superfície da fibra colágena.

Figura 4 - Incorporação de íons diferentes na molécula de hidroxiapatita, evidenciando os sítios específicos de troca

Figura 5 - Desenho esquemático do aparelho de micro-CT mostrando os diferentes componentes. Notar que nesse aparelho a amostra que ratociona. As radiografias são fornecidas em duas dimensões para o computador, o qual, através de um programa específico de reconstituicão de imagens, cria um modelo em três dimensões e quantifica os resultados.

Figura 6 - Materiais empregados para preenchimento do defeito ósseo (imagens dos materiais fora e dentro dos invólucros): a) Hidroxiapatita Sintética; b) Tendão Bovino Mineralizado e c) Bio-Oss / Geistlich

Figura 7- Relaxante muscular (Cloridrato de Xilazina - Anasedan®) e Anestésico Geral (Cloridrato de Ketamina - Flancotar $\left.{ }^{\circledR}\right)$. 
Figura 8 - Procedimento Cirúrgico: assepsia do campo operatório com lodo Povidine, tricotomia da região fronto-parietal, incisão do tegumento, descolamento total do periósteo expondo o tecido ósseo do crânio e trepanação com emprego de broca trefina de $8 \mathrm{~mm}$ de diâmetro. Aspecto do defeito ósseo bicortical e exposição de duramáter.

Figura 9 - Preenchimento da cavidade óssea com os materiais: hidroxiapatita sintética, tendão bovino mineralizado e Bio Oss, respectivamente .52

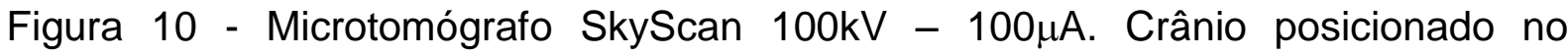
dispositivo de fixação e aparelho em funcionamento adquirindo as imagens através de Raios-X.

Figura 11 - Tela de trabalho do Sofware CTAnalyser ilustrando o desenvolvimento das etapas de reconstituição das imagens em 3D e quantificação dos resultados..54

Figura 12 - Reconstituição do tecido mineralizado da área interna do defeito ósseo. Notar o tecido mineralizado em cores e o tecido mole em negro (diâmetro de $8 \mathrm{~mm})$ .55

Figura 13 - Curvas termogravimétricas para o tendão bovino mineralizado e não mineralizado $\left(\operatorname{ar} 10^{\circ} \mathrm{C} \mathrm{min}^{-1}\right)$

Figura 14 - Curvas DSC para tendão bovino, tendão bovino mineralizado e tendão bovino mineralizado e esterelizado

Figura 15 - Micrografia de MEV da superfície do tendão bovino mineralizado (aumento 500x)

Figura 16 - Micrografia de MEV da superfície do tendão bovino mineralizado (aumento 5000x)

Figura 17 - Micrografia de MEV da secção transversal do Bio-Oss (aumento 50x)..61 Figura 18 - Micrografia de MEV da secção transversal do Geistlich Bio-Oss (aumento $500 x)$

Figura 19 - Imagens em três dimensões obtidas a partir de microtomografia computadorizada: anatomia craniana do rato Wistar controle íntegro. Observar sutura óssea fronto-parietal onde foi realizado o defeito 
Figura 20 - Imagem em três dimensões do controle da cirurgia sem enxerto após 30 dias

Figura 21 - Imagens em três dimensões do reparo ósseo dos sítios enxertados com hidroxiapatita sintética após 30 dias de cicatrização ( $n=5$ animais, vista superior e lateral).

Figura 22 - Imagens em três dimensões do reparo ósseo dos sítios enxertados com tendão bovino mineralizado após 30 dias de cicatrização ( $n=5$ animais, vista superior e lateral)

Figura 23 - Imagens do reparo ósseo do grupo enxertado com Bio Oss após 30 dias de cicatrização ( $\mathrm{n}=4$ animais, vista superior e lateral) 66

Figura 24 - Fotomicrografias do defeito do grupo Bio-Oss. Notar a grande presença de partículas do material, envoltas por um tecido conjuntivo com muitas células e vasos. Presença de tecido recém formado em forma de rampa nas margens do defeito, principalmente próximo a dura-máter (HE aumento de 20x e 50x e Tricromio de Masson aumento de 50x)

Figura 25 - Fotomicrografias do defeito do grupo da HA sintética. Notar a presença de inúmeras partículas de menor tamanho do material, envoltas por um tecido conjuntivo com células e vasos. Presença de tecido recém formado em forma de rampa nas margens do defeito, principalmente próximo a dura-máter (HE aumento de 20x e 50x e Tricromio de Masson aumento de 50x)

Figura 26 - Fotomicrografias do defeito do grupo do tendão bovino mineralizado. Notar a reabsorção severa do material e a presença de um um tecido conjuntivo com poucas células e vasos. Presença mínima de tecido recém formado nas margens do defeito (HE aumento de 20x e 50x e Tricromio de Masson aumento de 50x) .73

Figura 27 - Fotomicrografias do defeito do grupo controle preenchido apenas com coágulo sanguíneo. Notar a perda do espaço do tecido ósseo e presença de um tecido conjuntivo com poucas células e vasos. Presença mínima de tecido recém formado nas margens do defeito (HE aumento de 20x e 50x e Tricromio de Masson aumento de 50x) 


\section{LISTA DE GRÁFICOS}

Gráfico 1- Média das medidas de Micro-CT dos três materiais estudados

68

Gráfico 2 - Média das medidas da avaliação histológica convencional para os três materiais estudados .76 


\section{LISTA DE TABELAS}

Tabela 1 - Classificação dos difentes tipos de enxertos ósseos. .25

Tabela 2 - Comparação entre os três materiais das medidas obtidas pela MicroCT. .67

Tabela 3 - Comparação entre os três materiais das medidas obtidas pela avaliação histológica convencional.

.75

Tabela 4 - Correlação entre as medidas da Micro-CT e da histologia convencional. .78 


\section{LISTA DE ABREVIATURAS}

\begin{tabular}{|c|c|}
\hline Asq & Amplitude semi-quartil \\
\hline BMP & Proteínas morfogenéticas ósseas \\
\hline BMP-2 & Proteínas morfogenéticas ósseas tipo 2 \\
\hline BV & Volume do tecido ósseo BV \\
\hline B-ТCP & Beta fosfato tricálcio \\
\hline DSC & Calorimetria exploratória diferencial \\
\hline FGF & Fator de crescimento de fibroblastos \\
\hline $\mathrm{HA}$ & Hidroxiapatita \\
\hline HE & Hematoxilina - Eosina \\
\hline HIV & Vírus da imunodeficiência humana \\
\hline IGF & Fator de crescimento insulina \\
\hline $\mathrm{mg}$ & Miligrama \\
\hline $\mathrm{mL}$ & Mililitro \\
\hline $\mathrm{mm}$ & Milímetro \\
\hline$\mu \mathrm{m}$ & Micrômetro \\
\hline$\mu m^{3}$ & Micrômetros cúbicos \\
\hline med & Mediana \\
\hline MEV & Microscopia Eletrônica de Varredura \\
\hline Micro-CT & Microtomografia computadorizada \\
\hline Nano-CT & Nanotomografia computadorizada \\
\hline ns & Diferença estatisticamente não significante \\
\hline OC & Osteocondução \\
\hline $\mathrm{Ol}$ & Osteindução \\
\hline OG & Osteogênese \\
\hline PDGF & Fator de crescimento derivado de plaquetas \\
\hline SE & Suporte estrutural \\
\hline TCP & Fosfato tricálcio \\
\hline $\mathrm{Td}$ & Temperaturas de desnaturação \\
\hline TGA & Análise termogravimétrica \\
\hline TGF-beta & Fator de crescimento de transformação beta \\
\hline TV & Volume total \\
\hline
\end{tabular}


VEGF

Fator de crescimento endotelial vascular

2D

Duas dimensões

$3 \mathrm{D}$

Três dimensões 


\section{SUMÁRIO}

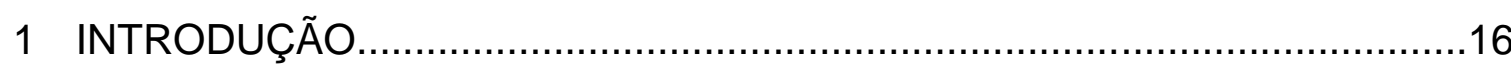

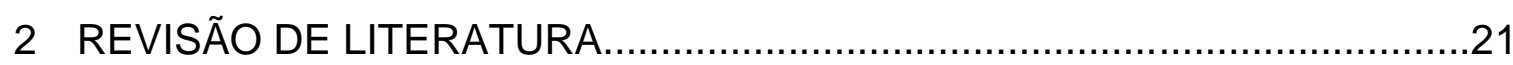

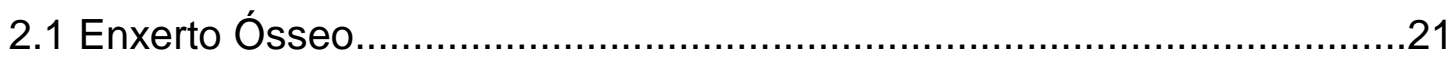

2.2 Hidroxiapatita e Colágeno Bovino.....................................................27

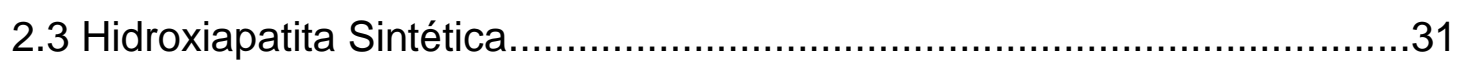

2.4 Microtomografia Computadorizada.....................................................38

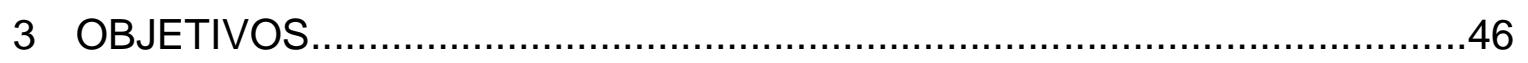

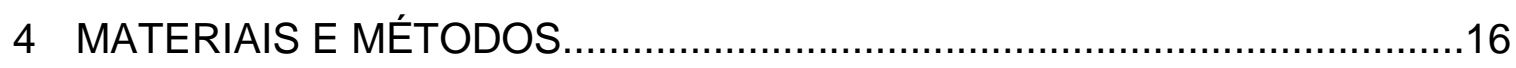

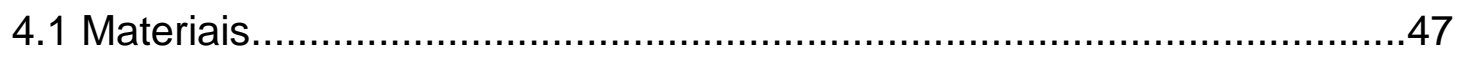

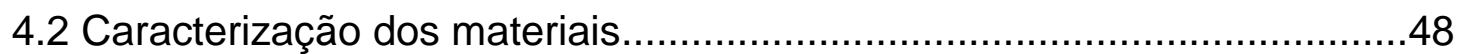

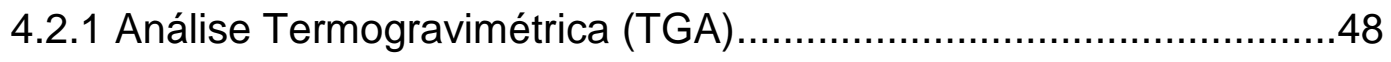

4.2.2 Calorimetria Exploratória Diferencial (DSC) ..................................49

4.2.3 Microscopia Eletrônica de Varredura (MEV) .................................49

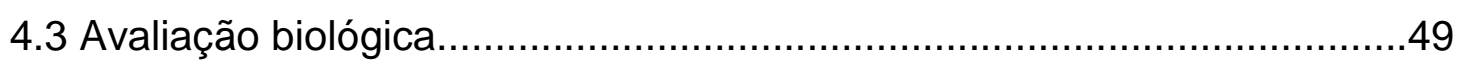

4.3.1 Reparo em defeito crítico de calvária.........................................50

4.3.2 Análise histológica e Microtomografia Computadorizada................52

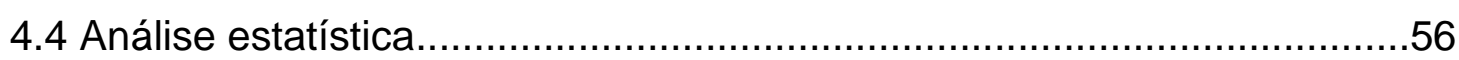

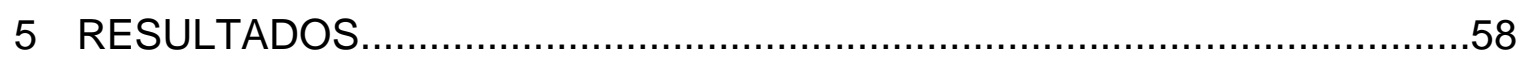

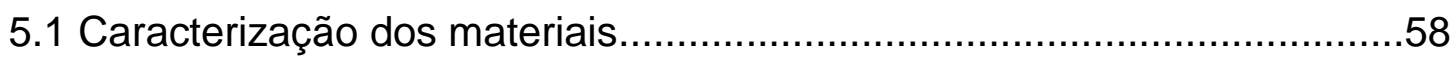

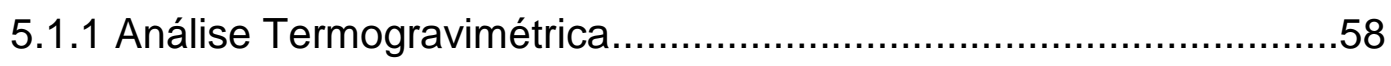

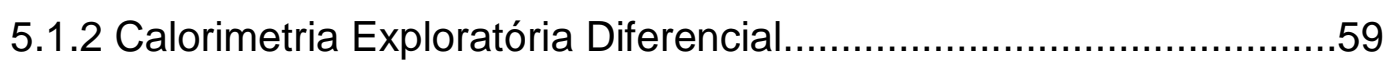

5.1.3 Microscopia eletrônica de Varredura.............................................59

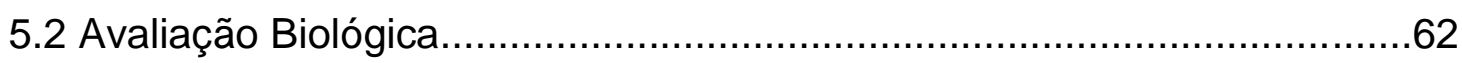

6 DISCUSSÃO

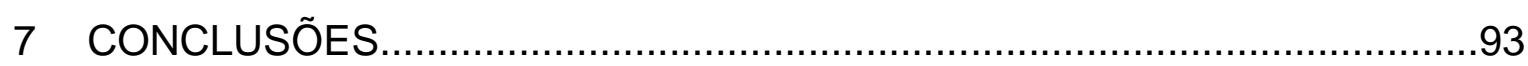

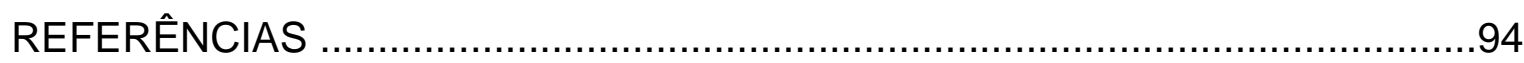

ANEXO: Certificado de aprovação pela Comissão de Ética em experimentação animal 


\section{INTRODUÇÃO}

Traumas, infecções, anomalias de desenvolvimento, patologias, ressecções oncológicas e perda fisiológica de massa óssea podem levar a defeitos ósseos perenes, os quais não tem a capacidade de se regenerar espontaneamente. Na região bucomaxilofacial, a reabsorção severa da mandíbula e maxila, associada à perda dos dentes, pode levar a defeitos anatômicos importantes comprometendo a função e a estética e, em muitos casos, inviabiliza a colocação de implantes dentários osseointegráveis de titânio para a reabilitação oral (LINDHE, 2005). Além do mais, defeitos ósseos extensos, principalmente em áreas estéticas, dificultam que o paciente desempenhe suas funções normais e tenha um bom convívio social, levando em muitos casos a problemas psicológicos de autoestima (KIM, 2010).

Para restaurar o tecido perdido, médicos e cirurgiões-dentistas realizam mais de um milhão de procedimentos envolvendo regeneração óssea a cada ano, só nos Estados Unidos da América (FIERZ, 2008). O enxerto ósseo autógeno obtido a partir de outras áreas do esqueleto com disponibilidade, como, por exemplo, crista ilíaca, calota craniana e mandíbula, ainda é o padrão ouro para estes procedimentos (DIMITRIOU, 2011). O enxerto autógeno ainda permanece como primeira escolha dos cirurgiões no tratamento regenerador do tecido ósseo, principalmente, devido a suas propriedades de osteocondução, osteoindução e osteogênese. A osteocondução é a capacidade do enxerto servir de arcabouço para o crescimento tecidual interno. À medida que o osso autógeno é reabsorvido, ele libera fatores de crescimento (proteínas ósseas morfogenéticas) que estimulam a formação óssea, caracterizando a osteoindução. A capacidade do enxerto autógeno levar células viáveis ao leito receptor é a osteogênese (HANDA, 2012).

Entretanto, o enxerto ósseo autógeno apresenta alguns inconvenientes como, necessidade de uma cirurgia adicional na área doadora, aumento de $20 \%$ a $30 \%$ na morbidade, maior período de convalescença, risco de contaminação da área doadora, risco de infecção da ferida cirúrgica, limitação em relação à quantidade, discrepância anatômica entre área doadora e receptora e aumento no custo final do tratamento (AGHDASI, 2012).

O enxerto alógeno fresco congelado, oriundo de banco de tecidos humanos, seria uma alternativa ao autógeno, porém muita controvérsia há em relação à 
possibilidade de transmissão de doenças, reações imunogênicas e muitos pacientes não aceitam tecidos oriundos de cadáveres (JIANG, 2012).

Devido a essas limitações do enxerto autógeno e alógeno nas cirurgias de regeneração do tecido ósseo, o cirurgião encontra muita dificuldade em encontrar um substituto ósseo ideal (YONAMINE, 2010). Visando solucionar tal problema, atualmente, muitos materiais produzidos em laboratórios destinam-se ao preenchimento de defeitos ósseos extensos. Os materiais sintéticos tendem a ser mais empregados como enxerto ósseo devido a algumas vantagens como, por exemplo, ausência de contaminação, boa disponibilidade, facilidade de manuseio e boa aceitação por parte do paciente. Outra propriedade importante é a capacidade de adição de fármacos, moléculas e células de maneira controlada (LI, 2011).

Dentre os materiais sintéticos as cerâmicas apresentam-se como a principal alternativa na regeneração óssea. As cerâmicas são consideradas biomateriais biocompatíveis e com propriedades de tração baixas, porém com excelente força de compressão, alta resistência ao carregamento e baixas propriedades friccionais (LARSSON, 2010). A baixa resistência friccional é aumentada pelo fato das cerâmicas serem hidrofílicas podendo ser bem polidas, o que promove uma capacidade da superfície receber cargas de outros materiais ou do próprio organismo (BEN-NISSAN, 2003). Apesar das cerâmicas inorgânicas não demonstrarem capacidade osteoindutora, elas certamente apresentam excelente capacidade osteocondutora bem como uma notável capacidade de ligarem-se ao osso (ANDERSSON, 2010).

Muitos biomateriais sintéticos e biocompatíveis estão disponíveis no mercado em grande variedade de texturas, tamanhos, formas e composição (BEZERRA, 2002). As cerâmicas bioativas compõem a maior família dos aloplastos. Entre eles estão incluídos: Fosfato Tricálcio (TCP), hidroxiapatita (HA); sulfato de cálcio, carbonato de cálcio; polímeros a base de hidróxido de cálcio; cerâmicas de vidro bioativo (VAL, 2012).

A hidroxiapatita e o fosfato de cálcio são as principais biocerâmicas utilizadas para o reparo de tecido duro devido a sua semelhança com os minerais do osso natural, sua excelente biocompatibilidade e bioatividade (CHU, 2002; PILLIAR, 2001). Grandes esforços têm melhorado significativamente as propriedades e o 
desempenho da hidroxiapatita e do fosfato de cálcio (CONVERSE, 2010; DEVILLE, 2006; MIRANDA, 2007; MIRANDA, 2008; SIMON, 2003; TAMAI, 2002).

Quando implantados no tecido ósseo, esses materiais bioativos como a hidroxiapatita e o fosfato de Cálcio proporcionam um ambiente ideal para as reações bioquímicas celulares e posterior colonização dos osteoblastos. Essa interface funcional promove o crescimento ósseo sobre o material levando a uma união biológica muito estável e com perspectiva de substituição do enxerto por osso natural, caracterizando a regeneração óssea (HENCH, 2002).

Com o avanço das técnicas cirúrgicas há uma demanda crescente de biocerâmicas com melhores propriedades para substituição do osso de uma maneira mais eficaz. As biocerâmicas porosas têm grande potencial para satisfazer essa demanda, expecialmente em defeitos extensos. No entanto, as propriedades mecânicas e o crescimento ósseo no interior do material de maneira relevante representam um fator determinante na aplicação desses materiais nas cirurgias reconstrutivas ósseas (JONES, 2007).

Com o objetivo de avaliar a regeneração óssea empregando-se diferentes tipos de materiais, alguns modelos animais foram propostos visando discriminar os eventos bioquímicos e celulales que ocorrem na reparação do tecido. Atualmente, o modelo animal mais utilizado é o chamado defeito de tamanho crítico em calvária, o qual foi definido como a menor ferida intra-óssea que não tem a capacidade total de cura por meio da formação óssea durante o tempo de vida do animal (REICHERT, 2009). Embora o tamanho mínimo do defeito em milímetros seja diferente para cada animal é consenso que para a calvária do rato Wistar o defeito circular deve ser de 8 mm (CACCHIOLI, 2006; EINHORN, 1999).

O modelo animal in vivo mais indicado para avaliação da osteocondutibilidade de biomateriais é o defeito perene em animais, ou seja, a criação de um defeito de tamanho crítico nos ossos frontal e parietais do crânio de ratos. Esse tipo defeito não tem a capacidade de regenerar-se por completo sem a utilização de enxerto ósseo $(\mathrm{BOSCH}$, 1998). Muitos biomateriais, especialmente os cerâmicos, foram empregados como enxerto ósseo nesses modelos de estudo e suas comparações podem ser padronizadas (FURLANETO, 2007; SODEK, 2000). 
Vários parâmetros biológicos devem ser avaliados no reparo do defeito ósseo como, por exemplo, quantidade de osso formado, remanecente do biomaterial, células presentes, vascularização e porosidade do biomaterrial. O tamanho e a interconexão dos poros dos biomateriais desempenham um papel crucial na formação do osso. Uma porosidade média de 100 a $150 \mu \mathrm{m}$ foi estabelecida inicialmente como ideal para o crescimento celular no interior do biomaterial, devido ao tamanho das células e transporte de nutrientes. Posteriormente, materiais com poros de aproximadamente $300 \mu \mathrm{m}$ mostraram melhores resultados devido a formação facilitada de capilares sanguíneos. Embora a porosidade seja importante, a interconectividade e acessibilidade da rede de poros é crucial para o crescimento ósseo (KARAGEORGIOU, 2005; OTSUKI, 2006).

A determinação dessas características estruturais que influenciam o crescimento ósseo tem representado um desafio significativo na análise histológica convencional, uma vez que dependem da interpretação anatômica tridimensional. Um grande número de cortes histológicos por amostra são necessários para se determinar quaisquer característica tridimensional do reparo ósseo, sendo operacionalmente muito complicado e demorado. Por este motivo, poucos estudos realizados detalharam as características tridimencionais do crescimento ósseo em materiais biocerâmicos porosos (JONES, 2004).

Em um trabalho de regeneração óssea guiada foi utilizado o sistema de microtomografia computadorizada (micro-CT) para mensurar aumento ósseo na calvária de ratos. A calota craniana foi exposta e foram criados defeitos de tamanho crítico de $5 \mathrm{~mm}$ bilateralmente. Duas tampas de resina foram colocadas com e sem hidroxiapatita (HA), e as imagens de aumento do osso no interior da tampa de resina foram obtidas utilizando micro-CT. Houve aumento ósseo no grupo com HA e observou-se uma continuidade do osso entre a borda do defeito e o biomaterial. Em contraste, nenhuma formação de osso novo foi observada no local do grupo controle. O sistema de micro-CT permitiu a observação contínua da regeneração óssea guiada com materiais de enxerto na calvária de rato (KOCHI, 2009).

Embora ainda não possa fornecer todas os dados de uma análise histológica, a micro-CT apresenta substancial vantagem na determinação das características estruturais e parâmetros de crescimento ósseo em três dimensões (GAUTHIER, 2005; HO, 2006). Dessa maneira, a micro-CT é uma técnica rápida e não destrutiva 
que caracteriza e mensura as propriedades tridimensionais do biomaterial e da regeneração do tecido ósseo. A análise histológica complementa a caracterização celular e corroboraria aos achados estruturais microtomográficos (JONES, 2004; KNACKSTEDT, 2006; PORTER, 2005).

Muitos trabalhos têm buscado intensivamente um substituto ósseo ideal utilizando biocerâmicas associadas ou não a compostos orgânicos para o reparo do defeito, porém ainda não se encontrou um material que substitua 0 enxerto autógeno. Além do mais, poucos estudos têm correlacionado de uma forma direta a análise histolológica e a microtomografia computadorizada. Dessa forma, estudos com novos biomateriais e análise estrutural através de microtomografia computadorizada se fazem necessários para a melhoria dos materiais e a elucidação dos eventos biológicos que regem a regeneração óssea. 


\section{REVISÃO DE LITERATURA}

\subsection{ENXERTO ÓSSEO}

O enxerto ósseo representa um procedimento padrão freqüentemente utilizado na regeneração óssea, sendo empregado nas mais diversas especialidades médicas como, ortopedia, oncologia, cirurgia plástica e, na área odontológica, na implantodontia e na cirurgia bucomaxilafacial. Na ortopedia, o enxerto ósseo é realizado, por exemplo, para estimular a cicatrização óssea em cirurgias de traumas de grandes proporções, não-uniões, fusões articulares, necrose avascular e na reconstrução de membros. Na odontologia, é muito utilizado em cirurgias reconstrutivas dos maxilares prévia a coloção de implantes dentários de Titânio, regeneração periodontal e reconstrução de rebordo alveolar em fissuras labiopalatinas congênitas (DE LONG JR, 2007; FINKEMEIER, 2002; JENSEN, 2012).

O material de enxertia ideal para reconstrução óssea deve apresentar as seguintes características (BLOCK, 2006):

- Deve ter integridade estrutural para manter o espaço como arcabouço durante a instalação do enxerto, consolidação, maturação, e o completo reparo ósseo.

- Deve também, ser capaz de fornecer células para o local de destino para formar osso no interior do enxerto.

- O material deve ser capaz de ser reabsorvido, reformulado e substituído por osso natural viável.

- O osso resultante regenerado deve ser estável ao longo do tempo, sendo capaz de receber carga funcional e implantes dentários, no caso dos maxilares.

- O material deve ter facilidade de colheita (se autógeno) e colocação, minimizando a duração do procedimento e maximizando assim o potencial para o sucesso do enxerto.

- O procedimento cirúrgico deve levar a uma morbidade mínima do paciente, deve ser previsivel com alta taxa de sucesso e de fácil repetição. 
Os enxertos ósseos podem ser classificados em relação as propriedades biológicas que apresentam quando instalados no leito receptor. Essas propriedades são a osteocondução, osteindução e osteogênese (DINOPOULOS, 2012).

A osteocondução é a capacidade do enxerto auxiliar a cicatrização através do seu arcabouço micro e macroscópico permitindo a infiltração vascular e a migração interna de elementos celulares envolvidos na formação do osso como células mesenquimais indiferenciadas, osteoblastos, osteoclastos, entre outros. Normalmente, a osteocondução é mais eficiente quando outras propriedades como a osteindução e a osteogênese estão presentes na mesmo material. A osteocondução parece ser otimizada em dispositivos que imitam não só a estrutura física do osso, mas também composição química do mesmo (GIANNOUDIS, 2005).

A osteoindução foi primeiramente demonstrada por Urist na década de sessenta, o qual realizou os primeiros estudos demonstrando a notável capacidade do osso induzir a formação óssea em sítios ectópicos, observando assim que o tecido ósseo poderia apresentar algumas moléculas que teriam a capacidade de serem isoladas e servirem como indutores de crescimento ósseo em outros locais. Desde então, o osso foi observado como um composto fisiológico complexo contendo minerais, proteínas e elementos celulares com propriedades únicas. $\mathrm{O}$ mineral estrutural e a matriz protéica fornecem arcabouço, nutrientes, proteínas e células para a formação de novo tecido ósseo, o qual sofre remodelação fisiológica constante e é passivel de sofrer danos severos e regenerar-se (URIST, 1965; YAO, 2009).

A osteoindução é o processo pelo qual células mesenquimais indiferenciadas (pluripotentes) e células osteoprogenitoras são induzidas a diferenciarem-se em osteoblastos após exposição a moléculas provenientes no enxerto. Essa cascata de eventos celulares é mediada por inúmeros fatores de diferenciação e crescimento, entre eles destacam-se a superfamília do fator de crescimento de transformação beta (TGF-beta) e as proteínas morfogenéticas ósseas (BMP's / DIMITRIOU, 2005).

A osteogênese é a formação de novo osso a partir de células mesenquimais indiferenciadas e células osteoprogenitoras vivas provenientes do enxerto ou oriundas do hospedeiro. Essas células tem um papel importante como progenitoras de osteoblastos, e são responsáveis por metade do equilíbrio homeostático anabólico e também regulam a osteoclastogênese através da expressão do RANKL 
e OPG. Diferentes conjuntos de mediadores moleculares interagem com células locais e circulantes para coordenar a cascata de cicatrização: estimuladores de inflamação (interleucina 1 e 6), estimuladores de proliferação (TGF-beta), fator de crescimento insulina (IGF), fator de crescimento de fibroblastos (FGF), fator de crescimento derivado de plaquetas (PDGF) e fator de crescimento endotelial vascular (VEGF). Os efeitos da estas moléculas sobre a proliferação e diferenciação de células indiferenciadas foram bem descritas in vitro (BIELBY, 2007).

Na fase aguda do reparo ósseo ocorre uma diminuição do fornecimento de sangue e da tensão de oxigênio levando a uma hipóxia tecidual. O lançamento do numerosas citocinas e fatores de crescimento induz o processo de cura da inflamação, angiogênese, condrogênese e finalmente a osteogênese. Células mesenquimais normalmente encontradas na medula óssea, periósteo, vasos sanguíneos e tecidos moles adjacentes se diferenciam células condrogênicas e células osteogênicas, proliferando-se. Os osteoblastos formam osso diretamente através de ossificação intramembranosa, enquanto os condroblastos iniciam um processo de formação de cartilagem no local do defeito, a qual é posteriormente substituído por osso através ossificação endocondral. Todos estes processos estão sob a influência dos fatores de crescimento, das interleucinas 1 e 6 e das proteínas ósseas morfogenéticas ósseas (MICLAU, 2000).

O crescimento vascular no interior do enxerto precede a formação de osso e é necessário durante todo o processo para que ocorra o reparo normal. Fatores angiogênicos, como, por exemplo, o fator endotelial vascular de crescimento (VEGF), desempenham um papel crítico na consolidação da reparo através da estimulação da proliferação vascular, angiogênese, aporte de nutrientes e oxigênio no interior do defeito. Acredita-se que a expressão do VEGF é regulada positivamente nos condrócitos e nos osteoblastos, em reposta a hipoxia, tal como é visto nos primeiros instantes do reparo ósseo. As proteínas ósseas morfogenéticas também são capazes de estimular produção de fator angiogênico em células locais, como os osteoblastos (ECKARDT, 2005). Alt et al. (2011) quantificaram a revascularização de materiais de substituição óssea na cicatrização de defeitos de fêmur de ratos através da micro-CT com resolução de $9 \mu \mathrm{m}^{3}$ e nano-CT com resolução de $3 \mu \mathrm{m}^{3}$. Na figura 1 podemos observar a interação do material com o 
tecido do hospedeiro no corte histológico e a reconstituição da revascularização em três-dimensões do defeito.
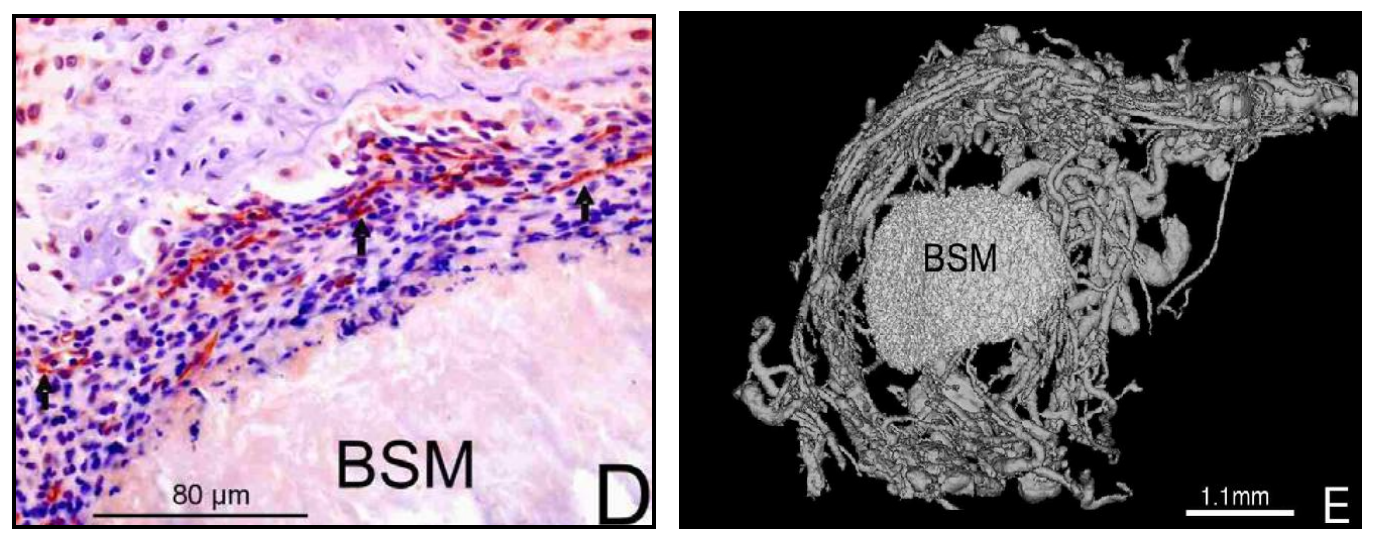

Figura 1 - Imagens do reparo ósseo de um material de substituição óssea. (D) corte histológico evidenciando a interação do material com as células do hospedeiro e os vasos sanguíneos. (E) reconstituição em três-dimensões do material e os vasos sanguíneos obtidos através da nano-CT

Fonte: Alt et al. (2011)

A rápida vascularização do enxerto ósseo é um processo importante para garantir o sucesso da osteogênese em longo prazo. Além disso, a amplitude da angiogênese está relacionada a estímulos presentes nos tecidos adjacentes, que permitem que os vasos preexistente iniciem a invasão do material de enxertia. A angiogênese é regulada por uma variedade de fatores de crescimento, particularmente o fator vascular endotelial de crescimento (VEGF), que é produzido por células estromais e células inflamatórias induzindo a invaginação dos vasos sanguíneos. Enxertos ósseos que não possuem células geralmente necessitam de mais tempo para vascularização, colonização celular e produção de matriz quando comparados ao enxerto autógeno (KERAMARIS, 2008).

Devido a grande diversidade de enxertos ósseos, diferentes sistemas de classificação têm sido propostos para tentar orientar o profissional no entendimento e na escolha do material. A Tabela 1 proposta por Laurencin, seguida de algumas pequenas modificações, não só classifica mas também oferece algumas características e propriedades resumidas dos materiais a partir da qual o cirurgião pode visualizar os diferentes tipos e escolher o material de enxerto mais adequado para cada caso (LAURENCIN, 2006). 
Tabela 1 - Classificação dos difentes tipos de enxertos ósseos

\begin{tabular}{|l|c|c|c|c|}
\hline \multicolumn{1}{|c|}{ ENXERTO OU SUBSTITUTO ÓSSEO } & OC & OI & OG & SE \\
\hline A. Enxerto ósseo & & & & \\
\hline - Enxerto Ósseo Autógeno & + & + & + & + \\
\hline - Medula Óssea & - & + & + & - \\
\hline - Enxerto Ósseo Alógeno & + & + & - & + \\
\hline - Matriz Óssea Desmineralizada (DBM) & + & + & - & - \\
\hline B. Fatores de Crescimento & & & & \\
\hline - Proteínas Ósseas Morfogenéticas (BMP) & - & + & - & - \\
\hline - Plasma Rico em Plaquetas (PRP) & - & + & - & - \\
\hline C. Substitutos Ósseos Celulares & & & & \\
\hline - Células Tronco & - & - & + & - \\
\hline - Terapia Genética & - & - & + & - \\
\hline D. Cerâmicas & & & & \\
\hline - Hidroxiapatita (HA) & + & - & - & + \\
\hline - Fosfato Tricálcio (TCP) & + & - & - & + \\
\hline - Vidro Bioativo & + & - & - & + \\
\hline - Sulfato de Cálcio & + & - & - & - \\
\hline - Cimentos Injetáveis & + & - & - & + \\
\hline E. Polímeros & & & & \\
\hline - Polímeros Naturais e Sintéticos & + & - & - & - \\
\hline - Polímeros Degradáveis e Não degradáveis & + & - & - & - \\
\hline F. Xenógeno (Origem Animal) & & & & \\
\hline - Hidroxiapatita Bovina & + & + & - & - \\
\hline - Hidroxiapatita Coralina & + & - & - & - \\
\hline
\end{tabular}

$\mathrm{OC}=$ Osteocondução; Ol=Osteindução; $\mathrm{OG}=$ Osteogênese; SE=Suporte Estrutural. Fonte: Laurencin (2006)

O enxerto autógeno é considerado o padrão ouro devido a ausência de antigenicidade, completa histocompatibilidade, proporciona as melhores propriedades osteocondutoras, osteoindutoras e osteogênicas (KHAN, 2005). Os enxertos autógenos geralmente contêm células osteogênicas viáveis (até 2 horas em solução salina normal) e proteínas da matriz óssea. Eles oferecem suporte estrutural, especialmente a parte cortical, que é incorporada ao leito receptor, sendo progressivamente reabsorvido e substituído por novo tecido ósseo (GREENWALD, 2001). A fonte mais comum deste tipo de enxerto é da crista ilíaca, mas também podem ser obtidos em menores quantidades da tíbia, calota craniana, mandíbula e maxila (ZOUHARY, 2010).

Embora os resultados biológicos do reparo ósseo do leito receptor sejam bastante satisfatórios, a colheita do enxerto da crista ilíaca está associada a uma série de complicações, como dor no local doador, hematoma, formação de neuroma, dor crônica inexplicada na coxa e infecção (MEADS, 2003). Dependendo da cirurgia 
e da quantidade de osso colhido, a prevalência de um ou mais dessas complicações pode variar entre 9\% a 49\% (SCHWARTZ, 2009). Além disso, o próprio processo adiciona uma média de 30 minutos para o tempo operatório em cirurgias em hospitais e internação extra em cirurgia ambulatorial (AHLMANN, 2002). Embora o enxerto ósseo autógeno apresentasse inicialmente um bom custo-benefício, observou-se posteriormente um maior custo direto e indireto com reabilitação pósoperatória, custo do tratamento da dor e tempo fora do trabalho (DAHABREH, 2009). Devido a alta morbidade, aumento tempo do operatório e custo elevado, os cirurgiões estão buscando materiais alternativos que possam substituir enxerto ósseo autógeno.

Uma alternativa ao enxerto ósseo autólogo é enxerto ósseo alógeno provenientes de cadáveres humanos. A principal vantagem do aloenxerto é ausência de morbidade e a ótima disponibilidade, já que ele pode ser obtido em várias formas, tamanhos e quantidade ilimitada. Os enxertos alógenos estão disponível em muitas apresentações, incluindo o osso liofilizado, a matriz óssea desmineralizada e o osso fresco congelado, dependendo dos requisitos do local destinatário. Geralmente, os aloenxertos ósseos têm boas propriedades osteocondutoras, reduzida propriedades osteoindutivas e nenhuma osteogenicidade, devido a ausência de células vivas, uma vez que são desvitalizados via irradiação ou tratamento de secagem por congelação. Entretanto, há questões controversas referentes a transmissão de vírus, especialmente o da imunodeficiência humana (HIV) e os da hepatite $B$ e $C$ e infecções bacterianas. A imunogenicidade, reações rejeições, assim como o custo elevado na obtenção, tratamento e conservação dos enxertos alogênicos acabam por contra-indicar sua utilização e sugerir a necessidade de substitutos ósseos alternativos (HOLTZCLAW, 2008).

Os enxertos xenógenos são substitutos ósseos provenientes de diferentes espécies. A principal fonte de xenotransplante comercializada como biomaterial de substituição óssea na prática clínica é a de origem bovina, como, por exemplo, a hidroxiapatita bovina, a matriz óssea desmineralizada, o colágeno, as membranas ósseas, entre outros. 


\subsection{HIDROXIAPATITA E COLÁGENO BOVINO}

Sendo o mais comum, o enxerto de osso bovino inorgânico é um derivado ósseo poroso e desproteinizado com a composição mineral comparável e estrutura microporosa do osso humano (HANKS, 2004). O osso bovino inorgânico tem apresentado ganhos significativos de tecido ósseo em nível clínico no preenchimento de defeitos intra-ósseo. Evidências histológicas em humanos mostraram de que o osso bovino inorgânico sozinho ou acompanhado do colágeno bovino podem proporcionar a regeneração em defeitos intra-ósseos (NEVINS, 2003).

Kramer et al. (2008) realizaram um estudo piloto experimental no qual substituiram o enxerto autógeno pelo osso inorgânico bovino esponjoso em defeitos de dimensão crítica de calvária em ovelhas adultas, e avaliaram após um período de consolidação de 28 dias. As amostras foram avaliadas por radiografia convencional, tomografias e histologicamente, incluindo imunofluorescência. Em ambos os grupos, a osteocondução propiciou a formação de novo tecido ósseo, o que indica que este biomaterial pode contribuir com êxito para a formação de osso. No entanto, o volume e a espessura do osso recém formado no local do defeito foram menores quando se utilizou o biomaterial. Os autores concluíram que a aplicação do osso bovino inorgânico em defeitos cranianos de tamanho crítico resultou na formação de novo tecido ósseo, evitando assim a necessidade do enxerto autógeno e excluíndo a morbidade do sítio doador.

Um substituto ósseo a base de osso bovino inorgânico amplamente utilizado na odontologia é o Bio-Oss ${ }^{\circledR}$ (Geistlich Pharma, Wolhusen, Suíça), o qual é frequentemente empregado, sozinho ou associado ao osso autógeno, em cirurgia de elevação do assoalho do seio maxilar (CHIAPASCO, 2009; JENSEN, 2009; NKENKE, 2009). Em um estudo clínico sobre o comportamento do Bio-Oss em regeneração óssea do seio maxilar, observou-se que havia uma melhora significativa na estabilidade volumétrica do enxerto, no ganho ósseo, na biomecânica e no contato osso implante após o aumento na proporção do Bio-Oss no enxerto (JENSEN, 2012).

O BioOss é um biomaterial inorgânico livre de patógenos que contém uma hidroxiapatita com estrutura cristalina e proporção cálcio/fósforo semelhante a hidroxiapatita humana. Block e Jackson (2006) mostraram a eficácia do BioOss em 
enxertia do alvéolo dentário após a extração e prévia a colocação de implante de titânio osseointegrável. A técnica para a utilização do osso bovino particulado é semelhante à descrita para o osso liofilizado humano, ou seja, deve-se aguardar de 4 a 8 meses para a colocação do implante dentário de titânio, conforme ilustrado na figura 2.
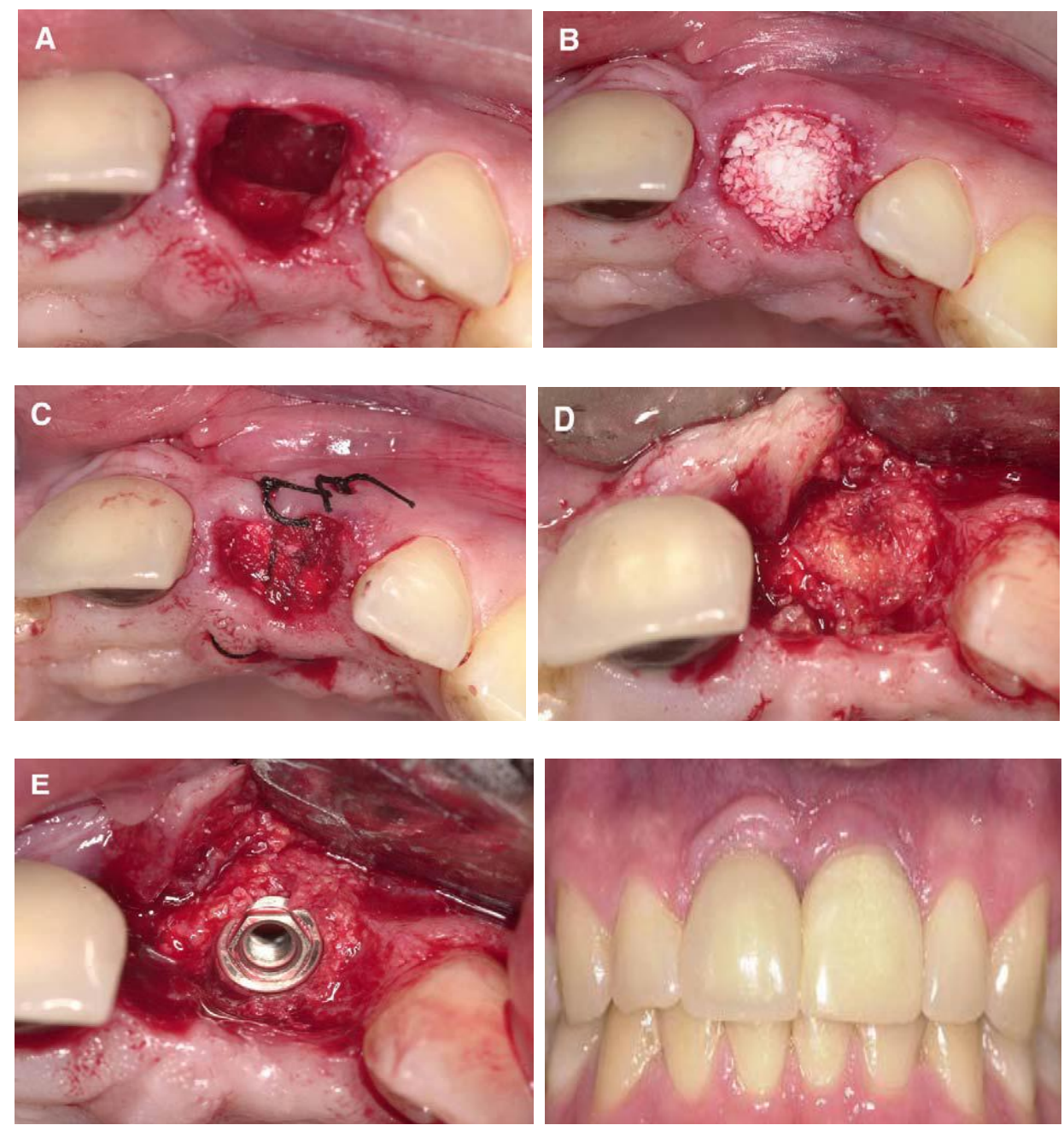

Figura 2 - Técnica cirúrgica de enxertia com Bio-Oss na maxila anterior. (A) extração do incisivo central superior exibindo perda óssea importante, o que inviabilizaria a colocação do implante de titânio; (B) osso bovino inorgânico compactado no interior do alvéolo ocupando todo o espaço anteriormente ocupado pela raiz dentária; (C) colocação de membrana de colágeno bovino e sutura; (D) aspecto do tecido ósseo reparado com volume satisfatório na cirurgia de reabertura quatro meses após para colocação do implante e (E) instalação do implante. Resultado final com instalação de coroa protética estética Fonte: Block e Jackson (2006)

Em outro estudo os autores investigaram a associação do osso bovino inorgânico a células tronco adultas derivadas do tecido adiposo como arcabouço para melhor formação óssea e osseointegração em um modelo de regeneração 
óssea guiada vertical. Duas cúpulas de titânio foram colocadas em cada calvária de 12 coelhos, sendo uma preenchida apenas com osso bovino inorgânico e a outra associado as células tronco. Após um mês, as cúpulas foram removidos e um implante de titânio foi colocado em cada local aumentado. Um mês após a segunda operação, os animais foram mortos e as biópsias foram examinadas por análise histomorfométrica e micro-CT. Os resultados indicaram que os grupos carregados com células tronco mostraram neoformação óssea significativamente maior, maiores valores médios de contato osso-implante e de densidade óssea que o grupo tratado apenas com osso bovino inorgânico. Este estudo sugeriu que a associação de células tronco ao osso bovino inorgânico pode efetivamente aumentar a regeneração óssea vertical e a osseointegração (PIERI, 2010).

Um inconveniente do osso bovino inorgânico é o seu alto custo de produção no processo de desproteinização, o que acaba por limitar seu uso principalmente no mercado brasileiro, ou ainda, até fornecer produtos de baixa qualidade ao paciente (WERBER, 2000). A indústria de biomateriais busca o desenvolvimento de substitutos ósseos osteocondutivos e osteoindutivos, disponibilizando alternativas eficientes a toda população com baixo custo (ITOH, 2002). Assim, a busca por materiais que satisfaçam tais requisitos impulsiona a criação de novas alternativas (LI, 2011; ROSE, 2004).

Como uma alternativa para a enxertia óssea, o colágeno foi extensivamente descrito como biomaterial para engenharia de tecido devido a sua biocompatibilidade, biodegradabilidade, baixa antigenicidade e alta resistência à tração (ROCHA, 2002). Adicionalmente, a presença de sequências de aminoácidos arginina-glicina-aspartato é responsável pelo reconhecimento e adesão celular (DU, 1999). Entretanto, arcabouços de colágeno puro não apresentam boas propriedades mecânicas devido a grande presença de espaços vazios, o que acaba atrapalhando a regeneração tecidual. Portanto, há uma demanda muito grande por melhoras nas propriedades mecânicas, químicas e biológicas do colágeno. Com esse objetivo, materiais inorgânicos como hidroxiapatita e fosfato de Cálcio foram adicionados as fibras colágenas para melhorar as características mecânicas e diminuir a taxa de degradação (MOREIRA, 2004).

Adicionalmente, Lawson et al. (1998) sugeriram que compósitos a base de fibras colágenas e fosfato de cálcio apresentaram boas propriedades mecânicas 
necessárias à enxertia óssea. Wahl et al. (2006) observaram que o osso natural é uma estrutura complexa de fibras colágenas e de cristais de hidroxiapatita, na qual as fibras colágenas proporcionam um reforço mecânico nos cristais de hidroxiapatita puros. O uso de compósitos de colágeno e hidroxiapatita têm sido bem documentados na área da engenharia de tecidos e na medicina regenerativa (HEMPEL, 2004). Esses compósitos empregados como arcabouço proporcionam excelentes propriedades biológicas in vivo (RODRIGUES, 2003).

Recentemente, pesquisadores investigaram o uso de fibras colágenas bovinas em cimentos de bruxita. Observou-se que o comportamento mecânico no trabalho de fratura do compósito melhorava com o aumento do nível de fibra colágena bovina. Eles observaram que o carregamento com fibra colágena bovina diminuía as falhas mecânicas normalmente associadas aos esses compósitos (MOREAU, 2009; TAMIMI, 2008). Entretanto, devido as superiores propriedades mecânicas e período de reabsorção maior é mais apropriado a utilização de compósitos a base de fosfato de Cálcio para a incorporação de fibras colágenas (BOHNER, 2000).

O'hara et al. (2012) estudaram o comportamento mecânico de cimentos de fosfato de cálcio incorporados a fibras colágenas bovinas em fraturas de vértebras. $\mathrm{Na}$ figura 3 podemos observar o ensaio mecânico de fratura do material e a mineralização da fibra colágena. Os autores concluíram que os cimentos de fosfato de cálcio reforçados com fibras colágenas apresentam um grande potencial para cirurgias de reparo das vértebras. 

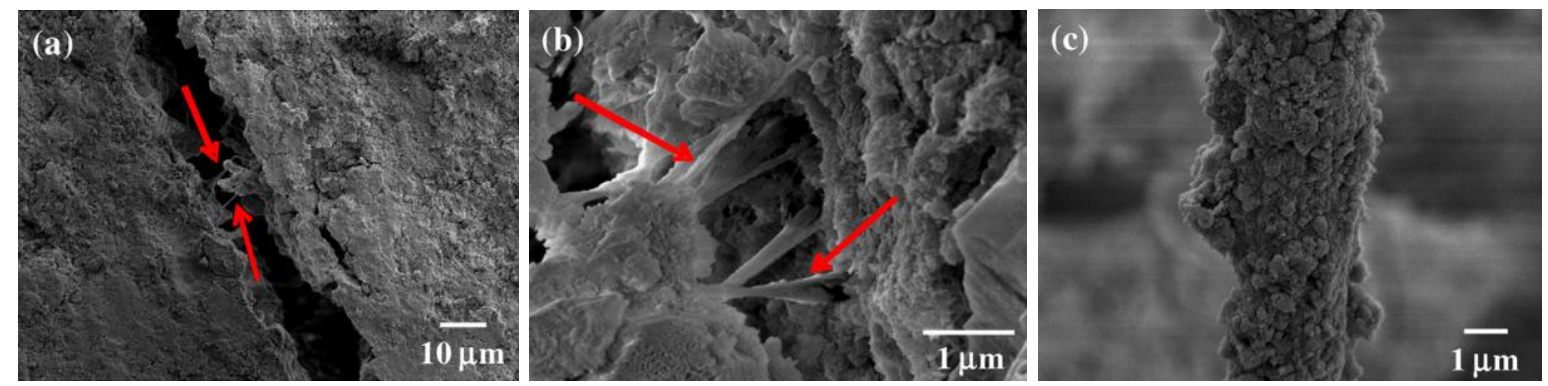

Figura 3 - Microscopia eletrônica de varredura do compósito de fosfato de cálcio e fibras colágenas bovinas: (a) fibras colágenas ainda aderidas as partes separadas por ensaio de compressão; (b) fibras colágenas entremeadas na matriz do cimento de fosfato de cálcio; (c) partículas de hidroxiapatita precipitadas na superfície da fibra colágena Fonte: O'hara (2012).

\subsection{HIDROXIAPATITA SINTÉTICA}

Os biomateriais cerâmicos são substitutos ósseos inorgânicos de origem sintética os quais apresentam excelente biocompatibilidade. A composição, morfologia e topografia da superfície das cerâmicas fornecem uma plataforma osteocondutora para promover a formação de osso ao longo da superfície do material de enxertia. O comportamento biológico de um material de enxerto aloplástico depende principalmente da sua composição química, estrutura e propriedades físicas (REYNOLDS, 2010).

Nas últimas décadas, enxertos ósseos a base de materiais cerâmicos têm sido amplamente utilizados para a regeneração óssea e funcionam principalmente através de osteocondução. Os materiais cerâmicos mais comuns comercialmente disponíveis no mercado são as biocerâmicas, como, por exemplo, o fosfato tricálcio e a hidroxiapatita, o sulfato de cálcio, e o vidro bioativo (BOCCACCINI, 2005). Essas cerâmicas também têm sido consideradas osteointegráveis, devido a sua íntima e tenaz ligação entre o material de enxertia e o novo tecido mineralizado. As cerâmicas podem existir em fases totalmente amorfas ou cristalinas, com proporções fixas e variáveis de seus constituíntes, principalmente o Cálcio e o Fósforo. Diferenças no grau do arranjo cristalino pode influenciar significativamente nas 
características físicas, químicas e biológicas da cerâmica, incluindo a resistência mecânica, taxa de dissolução e reabsorção (SCHEER, 2009; THOMAS, 2009).

A hidroxiapatita é uma cerâmica biocompatível produzida através de uma reação em alta temperatura e é uma forma de fosfato de cálcio altamente cristalina. A principal propriedade dessa cerâmica é sua semelhança química com a fase mineral do osso. Devido a essa similaridade ela apresenta excelente biocompatibilidade e osteocondução (HAK, 2007). O beta-fosfato de cálcio, é semelhante aos precursores amorfos do osso, ao passo que a hidroxiapatita é semelhante a fase mineral do osso, sendo assim mais complexa (BOHNER, 2000). As cerâmicas sintéticas não têm propriedades osteogênicas ou osteoindutora, devido a ausência de proteínas e células. Uma mistura de hidroxiapatita e fosfato tricálcio na proporção 60 : 40 proporciona um enxerto ósseo com uma interface osso-implante com boa propriedade biológica, mas com baixa resistência mecânica, o que pode atrapalhar a regeneração se cargas excessivas forem empregadas na fase inicia de integração (BALÇIK, 2007). A hidroxiapatita é um excelente carreador de moléculas osteoindutivas e células osteogênicas, tornando este material também útil na engenharia de tecidos (GHOSH, 2008).

A formação de osso em defeitos de tamanho crítico de calvária é fortemente dependente das propriedades de osteocondução dos enxertos. A substituição do enxerto autógeno por biomateriais continua a ser um assunto controverso, e se a suplementação dos biomateriais com proteínas ósseas morfogenéticas aumentaria a formação óssea. Luvizuto et al. (2011) trataram os defeitos de tamanho crítico em calvária de ratos de $5 \mathrm{~mm}$ de diâmetro com beta-fosfato tricálcio, ácido poliláctico associado ao gel de ácido poliglicólico e cimento de fosfato de cálcio, quer isoladamente ou na presença de $5 \mathrm{mg}$ de BMP-2. O enxerto autógeno e defeitos não tratados serviram como controles. Após 45 dias, a formação óssea foi avaliada com base na análise de micro-CT, análise histomorfométrica e análise de fluorescência. Foi relatado que o beta-fosfato tricálcio proporcionou a formação óssea de forma mais eficiente do que os outros substitutos. A formação de osso na presença de TCP sozinho alcançado um nível máximo, tal como a suplementação com BMP-2 não aumentou significativamente a formação óssea. Conclui-se que as propriedades de osteocondução do beta-fosfato de cálcio são superiores as do enxerto autógeno e de que esse biomaterial não requer suplementação de BMP-2 (LUVIZUTO, 2011). 
A hidroxiapatita desempenha também um papel de carreador de indutores de crescimento ósseo. Em um estudo foi descrito o emprego da hidroxiapatita $(\mathrm{HA})$ associada ou não a proteína óssea morfogenética (BMP) em defeitos de tamanho crítico em calvária. Vinte ratos Wistar machos foram divididos em quatro grupos de cinco animais cada: controle, HA, BMP e HA/BMP. Um defeito de tamanho não crítico foi feito realizado com uma trefina de $4 \mathrm{~mm}$ no osso calvária e em seguida foi aplicado os diferentes biomateriais de acordo com cada grupo. Os defeitos foram avaliados radiograficamente e histologicamente usando software ImageJ 4 semanas após a cirurgia. A maior radiopacidade foi observada no misto HA/BMP, seguida pela HA, BMP e, por último, o grupo de controle. Na análise histológica a maior taxa de osteogênese foi no grupo HA/BMP, seguido por BMP, HA e, por último, o grupo controle. No período de quatro semanas, a mistura HA/BMP mostrou o maior nível de indução ósseo, especialmente em comparação ao grupo de BMP. Isto revela a necessidade de um carreador cerâmico para a BMP. A associação da HA a indutores ósseos tem um efeito positivo sobre a osteogênese em defeitos críticos (NOTODIHARDJO, 2012).

A porosidade ideal para um material biocerâmico deve ser semelhante a do osso esponjoso. Demonstrou-se que a microporosidade de tamanho $<10 \mu \mathrm{m}$ permite a circulação de fluido corporal, ao passo que a macroporosidade de tamanho > $50 \mu \mathrm{m}$ fornece arcabouço e a porosidade entre 100 e $200 \mu \mathrm{m}$ favorece a colonização celular (DACULSI, 1998). As camadas superficiais amorfas de fosfato tricálcio reforçam a ligação com o osso adjacente do hospedeiro, estimulando a reabsorção osteoclástica e formação osteoblástica de novo tecido ósseo dentro do implante reabsorvido. A hidroxiapatita é um material frágil e sofre reabsorção lenta, portanto esses implantes podem sofrer tensão mecânica excessiva e falharem. Muitas vezes, a combinação com outros materiais podem melhorar os resultados com uma reabsorção mais rápida. A construção de uma cerâmica com maior porosidade e densidade mais baixa proporciona uma área de superfície maior para a vascularização e crescimento ósseo (NANDI, 2010). Os materiais cerâmicos têm sido usados para revestir e melhorar a osteointegração dos implantes de Titânio (MORONI, 2005; NGUYEN, 2004).

Os materiais cerâmicos podem também ser disponibilizados na formulação injetável. O beta fosfato tricálcico Ultraporous é um material de preenchimento 
altamente poroso, que é composto por um 90\% de espaços vazios interligados por uma ampla gama de tamanhos de poros de 1 a $1000 \mu \mathrm{m}$, mimetizando a estrutura trabecular do osso esponjoso. A porosidade do material permite a reabsorção fagocitária, a infiltração de nutrientes, células osteoprogenitoras e fatores de crescimento para regeneração óssea (SANCHES-SOTELO, 2000).

A hidroxiapatita (HA) faz parte de um grupo de minerais chamados apatitas e possui a fórmula química $\mathrm{Ca}_{10}\left(\mathrm{PO}_{4}\right)_{6}(\mathrm{OH})_{2}$, sendo caracterizada pela baixa solubilidade em sistemas aquosos ( $\mathrm{pKs}=147$ ), e bastante solúvel em soluções ácidas (BET, 1995; TADIC, 2004; VIDEAU, 1991).

A hidroxiapatita pode ser obtida por desproteinização do tecido ósseo (MANGANO, 2007; PARK, 1984) ou por tratamento hidrotérmico de corais (CAI, 2011; WHITE, 1986). Pode ser obtida também por processos sintéticos tais como, precipitação a partir de soluções aquosas ou reações de estado sólido (NANDI, 2008; OSAKA, 1991). No processo sintético através da precipitação em soluções aquosas a HA é preparada pela mistura de soluções aquosas de $\mathrm{PO}_{4}^{-3}$, na forma de $\mathrm{NH}_{4} \mathrm{H}_{2} \mathrm{PO}_{4},\left(\mathrm{NH}_{4}\right)_{2} \mathrm{HPO}_{4}$ ou $\mathrm{H}_{3} \mathrm{PO}_{4}$ e $\mathrm{Ca}^{+2}$ na forma de $\mathrm{CaCO}_{3}, \mathrm{CaCl}_{2}$ e $\mathrm{Ca}\left(\mathrm{NO}_{3}\right)_{2}$. A HA obtida por este método pode conter quantidades diferentes de $\mathrm{H}^{+}$e $\mathrm{OH}^{-} \mathrm{e}$ também ocorrer a substituição do íon Cálcio por íons estranhos presentes nas soluções aquosas, como podemos observar na figura 4. No método de reação no estado sólido a HA é preparada por um tratamento térmico $\left(900-1300^{\circ} \mathrm{C}\right.$ por 1 a 24 horas) de uma mistura estequiométrica de fosfato tricálcio ( $\beta$-TCP) ou $\mathrm{Ca}_{2} \mathrm{P}_{2} \mathrm{O}_{7}$ com $\mathrm{CaCO}_{3}$ ou $\mathrm{CaO}$ na presença de pressão de vapor (MUNAR, 2006; LEGEROS, 2002).

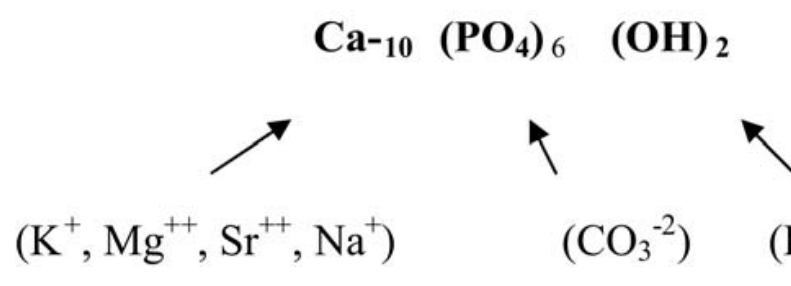

Figura 4 - Incorporação de íons diferentes na molécula de hidroxiapatita, evidenciando os sítios específicos de troca 
A reação química abaixo mostra um método convencional de preparação de hidroxiapatita em uma mistura de soluções aquosas de $\mathrm{Ca}\left(\mathrm{NO}_{3}\right)_{2}$ e $\mathrm{NH}_{4} \mathrm{H}_{2} \mathrm{PO}_{4}$ sob condições alcalinas, como mostrado na reação:

$$
10 \mathrm{Ca}\left(\mathrm{NO}_{3}\right)_{2}+6 \mathrm{NH}_{4} \mathrm{H}_{2} \mathrm{PO}_{4}+14 \mathrm{NH}_{4} \mathrm{OH} \rightarrow \mathrm{Ca}_{10}\left(\mathrm{PO}_{4}\right)_{6}(\mathrm{OH})_{2}+20 \mathrm{NH}_{4} \mathrm{NO}_{3}+12 \mathrm{H}_{2} \mathrm{O}
$$

A preparação da HA utilizando-se do ácido fosfórico e hidróxido de cálcio não é viável do ponto de vista de biomateriais, pois suas propriedades físicas e químicas não são reprodutíveis em função da baixíssima solubilidade do hidróxido de cálcio (OSAKA, 1991). Os problemas que ocorrem durante a síntese devem-se a parâmetros como temperatura, agitação e umidade no processo de calcinação, obtendo-se HA com relação cálcio e fósforo variando entre 1,5 e 1,67 (CUNHA, 2006).

A variação na proporção entre cálcio e fósforo segue o padrão estequiométrico mostrado na equação:

\section{$\mathrm{Ca}_{10-x}\left(\mathrm{HPO}_{4}\right)_{x}\left(\mathrm{PO}_{4}\right)_{6-x}(\mathrm{OH})_{2-x}$, sendo $0<\mathrm{x}<2$}

Defeitos e doenças do tecido ósseo como, neoplasias, infecção e má formação são apenas alguns de muitos problemas que acometem o tecido e para serem regenerados dependem dos biomateriais. Biomateriais sintéticos para 0 reparo tecidual apresentam-se em íntimo contato físico e biológico com os tecidos vivos, necessitando dessa forma manter uma ligação efetiva com o tecido hospedeiro. Cerâmicas bioativas como Bioglass ${ }^{\mathrm{TM}}$, $\beta$-fosfato tricálcio sinterizado, cerâmicas vítreas e hidroxiapatita sinterizada $(\mathrm{HA})$ são materiais que levam a uma integração íntima entre tecido e material in situ $(\mathrm{HENCH}, 1991$; KOKUBO, 2003; LU, 2002; MALMSTRÖM, 2007).

A hidroxiapatita densa, porosa, particulada e de revestimento tem sido um importante biomaterial de reparo e preenchimento de tecido duro, tendo sido reportada com sucesso em numerosos casos clínicos nas três últimas décadas (KIM, 2001). De fato, na clínica, observamos que as aplicações da HA direcionam as 
pesquisas ao desenvolvimento de novos compostos com características físicoquímicas mais adequadas no sentido de suportar cargas funcionais e desempenhar uma resposta biológica controlada (HENCH, 1998; STAFFA, 2007).

Através dos avanços na aplicação clínica da HA, existiram muitos estudos que focaram na análise química superficial in vitro e in vivo, o que tem inspirado estratégias de mudanças para o desenvolvimento de novos biomateriais bioativos com melhores propriedades físicas, químicas e biológicas. Entre as estratégias mais inovadoras estão os processos biomiméticos e modeladores acelulares livres de proteínas que imitam o mecanismo de biomineralização de nano cristais de fosfato de cálcio sobre a HA nos tecidos biológicos (KIM, 2003).

Materiais sintéticos são geralmente isolados dos tecidos vivos por uma cápsula fibrosa de tecido conjuntivo não aderente. A integração da hidroxiapatita ou das biocerâmicas em geral ao tecido ocorre através da biomineralização na interface tecido / biocerâmica. O processo é normalmente independente do tipo de biocerâmica (densa ou porosa/ bloco ou particulada/ compósitos/ fosfatos ou silicatos/ vitrocerâmicas e HA), e revela a presença de uma fina camada de fosfato de Cálcio (NEO, 1992). Achados histológicos em modelos animais revelam que esta camada de fosfato de Cálcio é formada na superfície das biocerâmicas num período de implantação curto, e posteriormente integra-se a matriz óssea como parte do metabolismo tecidual ( MASTROGIACOMO, 2007; OHURA, 1991).

Estudos de caracterização têm especificado que o fosfato de Cálcio da interface consiste em nano cristais de apatita que diferem da HA sintética $\left(\mathrm{Ca}_{10}\left(\mathrm{PO}_{4}\right)_{6}(\mathrm{OH})_{2}\right)$ na composição e estrutura. A apatita é uma HA de baixa cristalinidade deficiente em cálcio contendo sódio, magnésio, cloro, carbonato e com defeitos estruturais (KITSUGI, 1990). Especificamente, o fosfato de cálcio sobre as biocerâmicas exibe uma semelhança com a fase mineral do tecido ósseo. Esse tipo de camada de fosfato de cálcio não é observado ao redor de metais, polímeros e outros materiais não cerâmicos em defeitos teciduais, levando a crer que a superfície de biomineralização de fosfato de cálcio semelhante ao osso é um prérequisito para a bioatividade (DACULSI, 1990). O fosfato de cálcio pertencente a superfície da HA recruta células produtoras de osso, como, osteoblastos que se diferenciaram e proliferaram produzindo matriz extracelular composta de fosfato de cálcio e colágeno biológicos. Assim a HA apresenta uma fase mineral superficial 
semelhante a fase mineral óssea, o que, espontaneamente, estabelece uma integração química bastante íntima com o osso diminuindo a energia de interface (CAREY, 2005; KIM, 2003).

A regeneração óssea utilizando nano-hidroxiapatita foi avaliada no modelo de defeito ósseo crítico em calvária de coelhos. A regeneração óssea foi avaliada por micro-CT e análise histomorfométrica após 4 e 8 semanas. Todas as variáveis medidas através da análise de micro-CT foram significativamente melhores nos grupos enxertados com nano-HA do que nos grupos controle não preenchidos, tanto para 4 e 8 semanas. Considerando a rápida cicatrização de defeito ósseo e a boa disponibilidade a nano-HA, o estudo sugere que esse biomaterial poderia ser um bom substituto ósseo novo (KWEON, 2011).

Com o intuito de criar cerâmicas com melhores propriedades biológicas foi desenvolvido um composto poroso de fosfato de cálcio bifásico, revestindo com uma camada de nano partículas de hidroxiapatita e policaprolactona. Foram examinados os efeitos do tamanho e da forma das partículas da camada de revestimento de HA sobre as propriedades mecânicas e biológicas do andaime fosfato de cálcio. A análise por micro-CT mostrou que o material experimental era altamente poroso (91\%), com tamanho de poros de grandes dimensões $(400-700 \mu \mathrm{m})$ e uma rede altamente interligada (100\%). As amostras com revestimento de nano-HA apresentaram melhor resistência à compressão em comparação ao fosfato de cálcio puro. Estes biomateriais apresentaram elasticidade melhorada e algumas propriedades mecânicas semelhantes ao osso natural. Induziram a diferenciação das células pluripotentes em células ósseas humanas, com regulação positiva significativa da expressão do gene osteogênico (RUNKL, o colágeno tipo I, osteocalcina e sialoproteína óssea) e atividade da fosfatase alcalina. Estas propriedades são essenciais para melhorar o crescimento ósseo das cerâmicas nos defeitos críticos. O fosfato de cálcio com revestimento de nano-HA possui propriedades mecânicas e biológicas superiores, tornando-o potencialmente útil para a regeneração do tecido ósseo (ESFAHANI, 2010). 


\subsection{MICROTOMOGRAFIA COMPUTADORIZADA (Micro-CT)}

A tomografia computadorizada é uma técnica de imagem morfológica não destrutiva que pode quantificar a estrutura interna de um objecto em três dimensões. Ela fornece imagens biológicas com resoluções isotrópicas que vão desde alguns milímetros nos aparelhos clínicos de tomografia computadorizada, passando por algumas dezenas de micrômetros nos aparelhos laboratoriais de micro-CT e, finalmente chegando, nos aparelhos de radiação sincrotrônica, a resolução abaixo de $100 \mathrm{~nm}$. Atualmente, ocorreram muitos aprimoramentos na aquisição e análise de imagens de micro-CT para o osso trabecular e biomateriais empregados na regeneração óssea (POLAK, 2012).

$\mathrm{O}$ aparelho de micro-CT é composto por um feixe incidente de raios- $X$ policromático que é projetado sobre a amostra, a qual está fixada a uma plataforma rotacional. Esse feixe inicial é atenuado pela massa da amostra e um feixe resultante atravessa a amostra e sensibiliza uma tela sensível a raio-x. Atrás da tela há uma câmera que adquire imagens em duas dimensões e envia a um computador, o qual processa e analisa a imagens através de programas específicos (Figura 5).

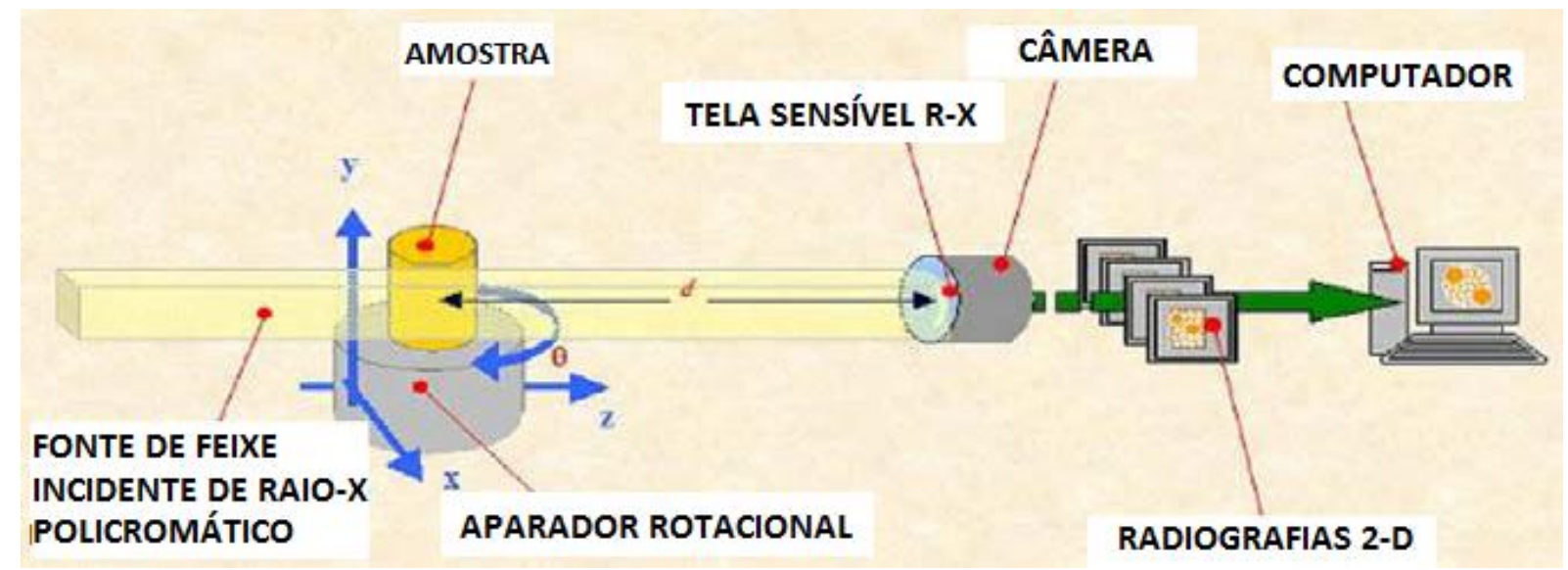

Figura 5 - Desenho esquemático do aparelho de micro-CT mostrando os diferentes componentes. Notar que nesse aparelho a amostra que ratociona. As radiografias são fornecidas em duas dimensões para o computador, o qual, através de um programa específico de reconstituicão de imagens, cria um modelo em três dimensões e quantifica os resultados 
Os primeiros avanços na tecnologia da micro-CT focavam nos aspectos metodológicos e os equipamentos necessários não eram amplamente disponíveis (FELDKAMP, 1989). Posteriormente, o desenvolvimento enfatizou os aspectos práticos dos micro cortes tomográficos (RÜEGSEGGER, 1996). Diferentes tipos de sistemas de micro-CT estão disponíveis comercialmente e podem ser utilizados rotineiramente nos laboratórios de pesquisa básica e clínica. De fato, a micro-CT tornou-se uma técnica padrão de avaliação da micro arquitetura trabecular em três dimensões (SOHIER, 2009).

O sistema de imagem de micro-CT foi utilizado para a análise microestrutural de compósitos osteocondutores bioabsorvíveis. Os compostos estudados foram conhecidos por ter uma estrutura porosa, mas a porosidade desses compostos não era totalmente medida devido à falta de interligação entre os poros. Essa microestrutura foi estimada utilizando microscopia eletrônica de varredura. Isto produziu uma estimativa muito grosseira do microestrutura com base apenas na estimativa da superfície e, portanto, a análise de imagens por micro-CT da porosidade total e distribuição de carga volumétrica foi realizada. $\bigcirc$ material de preenchimento foi o vidro bioativo e o beta-fosfatotricálcio. Os resultados ilustram a possibilidade da micro-CT analisar as microestruturas dos compósitos bioabsorvíveis de osteocondução. Em especial, a análise volumétrica tridimensional da distribuição das partículas de preenchimento no interior do compósito apresentou resultados inéditos (NIEMELÄ, 2011).

Conhecido como aparelhos de micro-CT de mesa, estes sistemas fornecem resoluções nominais que variam de 5 a $100 \mu \mathrm{m}$. Podem ser aferidas amostras com diâmetros variando de poucos milímetros a, no máximo, 100 mm. Aparelhos microCT de mesa proporcionam uma técnica precisa e validada, que tem sido amplamente utilizado para projetos de pesquisa envolvendo microarquitetura óssea (ALEXANDER, 2001; BOHNER, 2005), crescimento ósseo (GULDBERG, 2004) e, dada a estrutura porosa da maioria dos biomateriais, a micro-CT é também adequada para caracterização dos arcabouços estruturais (NIEMALÄ, 2011).

O princípio físico aplicado na obtenção da imagem de micro-CT convencional baseia-se na atenuação dos raios-X. Nos ossos, a atenuação é em grande parte causada pelos cristais minerais de hidroxiapatita, portanto, não é nenhuma surpresa que os biomateriais à base de hidroxiapatita sintética e de fosfato 
de cálcio possam proporcionar imagens semelhantes de boa qualidade (O'NEILL, 2012).

A porosidade é um parâmetro de suma importância no crescimento tecidual no interior dos biomateriais. O tamanho dos poros, suas interligações, a permeabilidade e a superfície do biomaterial constituem parâmetros importantes na concepção geométrica de um substituto ósseo. Em um estudo empregando-se aquisição de imagens por micro-CT, quatro grupos de biomateriais com características geométricas distintas, mas porosidade constante foram escaneados e suas medidas geométricas foram determinadas utilizando um algoritmo de processamento de imagem. Os substitutos foram produzidos utilizando o método de emulsão de fosfato de cálcio. A análise geométrica revelou a elevada reprodutibilidade do método de emulsão. Apesar de existir algumas diferenças no tamanho dos poros, o tamanho da interligação apenas aumentou ligeiramente com o aumento do tamanho dos poros. A superfície específica diminuiu com o aumento do tamanho dos poros. A permeabilidade aumentou com o tamanho dos poros e era inversamente proporcional à superfície específica. A micro-CT permite uma análise geométrica precisa, mesmo se a resolução da imagem está acima do tamanho dos poros. Além disso, é uma ferramenta excitante para compreender o mecanismo de povoamento celular dos biomateriais objetivando-se $\mathrm{o}$ projeto de melhores substitutos ósseos (ZADEH, 2010).

As análises quantitativas da arquitetura dos biomateriais foi facilitada em grande parte pelo aprimoramento da metodologia já desenvolvida para o osso trabecular. No passado, as propriedades estruturais do osso trabecular foram investigadas através do exame histomorfométrico de secções bidimensionais (2D) de biópsias ósseas. Os parâmetros morfométricos em três dimensões (3D) foram obtidos a partir de imagens 2D utilizando-se métodos estereológicos (PARFITT, 1983). Enquanto os parâmetros como superfície óssea e volume ósseo podem ser diretamente obtidos a partir de imagens 2D, uma série de parâmetros importantes, tais como o número, a espessura e a separação das trabéculas são indiretamente calculados assumindo um modelo fixo estrutural. Para este efeito, vários novos métodos de processamento de imagem 3D através da micro-CT, foram recentemente apresentados para osso trabecular permitindo a quantificação direta da arquitetura micro-estrutural com bastante precisão e facilidade, como, por 
exemplo, a densidade de volume ósseo, densidade de superfície óssea e interconectividade entre as trabéculas (GULDBERG, 2008).

Efeoglu et al. (2007) mostraram que a micro-CT é uma ferramenta útil para a aquisição de imagens tridimensionais de alta resolução para avaliar a cicatrização óssea, a interface com o material e a biocompatibilidade de substitutos de osso. Imagens adquiridas podem ser utilizados para análise morfométrica quantitativa não invasiva do osso em regeneração, deixando a opção da histologia convencional como um coadjuvante em intervalos definidos. A caracterização temporal da mineralização do osso tem um papel potencialmente importante na compreensão da dinâmica da mineralização dos ossos no processo de cura, especialmente para materiais degradáveis, bioativo e produtos farmacêuticos que atuam no osso.

Renghini et al. (2009) caracterizaram arcabouços de vitrocerâmicos bioativas reabsorvíveis com porosidade aberta e altamente interligada, semelhante a textura do osso esponjoso, através da micro-CT síncrotron com resolução de $1 \mu \mathrm{m}^{3}$. A utilização de radiação síncrotron permite a seleção de energia dos fótons que pode ser ajustado para otimizar o contraste entre as diferentes fases nas amostras investigadas.

Um material que foi amplamente avaliado como substituto ósseo é o fosfato de cálcio injetável, que tem a vantagem de ser utilizado em cirurgias minimamente invasivas. Foi determinado o crescimento ósseo utilizando-se esse material em defeitos de tamanho crítico na extremidade distal de fêmur de coelho através da micro-CT síncrotron de raios-X. As reconstruções em 3D permitiu distinguir as três fases que estavam presentes no interior do defeito, sendo, o osso recentemente formado, o biomaterial e o tecido conjuntivo. Além disso, as imagens altamente detalhadas mostram o crescimento ósseo no interior do biomaterial, incluindo as lacunas dos osteócitos e os vasos sanguíneos (WEISS, 2003). No entanto, essa técnica permite apenas avaliar amostras relativamente pequenas de aproximadamente $1 \mathrm{~mm}^{3}$ e, devido ao campo de visão limitado, não se permite avaliar a estrutura óssea na íntegra (LENTHE, 2007).

Com o objetivo de analisar o volume do reparo por completo, a micro-CT com uma resolução de $24 \mu \mathrm{m}$ foi realizada num modelo animal semelhante. Dessa forma, também foi possível avaliar de uma forma simples e direta do osso recémformado, o remanecente do biomaterial e o tecido conjuntivo. A micro-CT mostrou 
que o osso recentemente formado estava em continuidade com o osso trabecular do hospedeiro e, também, a degradação do biomaterial. As medições quantitativas do osso neoformado e da degradação da cerâmica através da micro-CT correlacionaram-se positivamente com os resultados obtidos a partir de microscopia electrônica de varredura. Enquanto a microscopia eletrônica de varredura fornece imagens detalhadas sobre a integração das partículas de cerâmica a nova estrutura óssea, esta interface precisa foi menos claramente distinguível com a micro-CT. No entanto, a vantagem da micro-CT é a sua natureza 3D, que permite analisar o reparo ósseo por completo, e não de um número limitado de secções 2D. (GAUTHIER, 2005).

Weiss et al. (2007) relataram a primeira avaliação clínica de um substituto ósseo injetável em humanos. Este biomaterial foi constituído por suspensão de fosfato de cálcio bifásico com partículas de diâmetros variando entre 80 e $200 \mu \mathrm{m}$ em uma fase de polímero transportador de celulose solúvel em água, sendo utilizado para o preenchimento de defeitos ósseos após extrações de dentes em 11 pacientes. O objetivo do estudo foi investigar a segurança do material de preenchimento em alvéolos dentários humanos e a possível prevenção da perda da osso alveolar. Três anos após a cirurgia, pequenas biópsias das áreas implantadas foram colhidas e analisadas através da micro-CT e histomorfometria. Os grânulos de fosfato de cálcio apareceram em contato direto com o tecido ósseo mineralizado, apoiando assim o crescimento do osso. Foi observada a substituição gradual do material de preenchimento pelo tecido ósseo, preservando assim a altura da crista do osso alveolar.

Em um estudo de regeneração óssea utilizando-se beta-fosfato tricálcio em ovelhas através da micro-CT observou-se um reabsorção rápida da cerâmica e um crescimento ósseo no interior do material. Amostras com poros maiores apresentaram maior crescimento ósseo interno e reabsorção do material mais rápida. Não obstante, o processo exato do crescimento ósseo no interior do material permanece obscuro pelo fato da arquitetura interna do biomaterial não ser homogênea, apresentando poros com diferentes tamanhos (DOERNBERG, 2006).

Para se avaliar os efeitos do tamanho e da forma dos poros no crescimento ósseo dentro do material, nove diferentes desenhos de arcabouço com diferente espessura de traves e formas foram analisados. A técnica de fabricação livre de 
sólidos apresentou muitas vantagens, pois permitiu a criação de arcabouços com bastante rigor e precisão. Arcabouços de hidroxiapatita não reabsorvível de $8 \mathrm{~mm}$ de diâmetro e $6 \mathrm{~mm}$ de altura, com tamanho de poros variando entre 400 e $900 \mu \mathrm{m}$ e porosidade de $45 \%$ foram colocados em defeitos de tamanho crítico em mandíbulas de cobaias. Após 6 e 18 semanas, biópsias foram colhidas e realizada a análise com micro-CT com uma resolução de $15 \mu \mathrm{m}$ para quantificação do crescimento ósseo dentro e sobre o biomaterial. Foi encontrado que o volume ósseo era maior na periferia do material e diminuía em direção ao centro. Poros maiores facilitavam o crescimento do tecido ósseo no seu interior (HOLLISTER, 2005).

Um estudo de Weiss et al. (2003) utilizou microtomografia síncrotron de raios-X em uma escala um mícron para comparar crescimento ósseo tridimencional após a implantação de biomateriais a base de fosfato de cálcio no osso em um modelo defeito de tamanho crítico em coelhos. Esse método avaliou o crescimento interno e, em especial, na interface osso implante recem formada. Blocos cerâmicos macroporosos de fosfato de cálcio e dois diferentes cimentos injetáveis de fosfato de cálcio foram implantados in vivo, com resolução espacial experimental de 1 a 1,4 $\mu \mathrm{m}$. Todos os fosfatos de cálcio testados apresentaram osteocondução. Observações do cimento de fosfato de cálcio após reconstrução em 3D mostraram um biomaterial bioativo interconectato com macroporosidade aberta ao crescimento ósseo três semanas após a implantação. Esses achados foram corroborados a análise histomorfométrica em 2D. Os autores concluiram que com o aumento da porosidade e da interconectividade ocorria um aumento do crescimento ósseo no interior dos biomateriais.

O trabalho de Jones et al. (2004) utilizou da micro-CT para estudar o processo de crescimento ósseo através da aquisição de imagens dos biomateriais em três dimensões. Foi possível adquirir imagens compostas de $2000^{3}$ voxels em amostras de até $60 \mathrm{~mm}$ e com resoluções de até $2 \mu \mathrm{m}$, possibilitando a análise da ultraestrutura do tecido ósseo. A capacidade da micro-CT foi demonstrada pela exibição de imagens do complexo sistema de canalículos de Havers da cortical do fêmur humano (diáfise distal) e do crescimento ósseo no interior do arcabouço poroso do biomaterial. Estas observações mostram os benefícios da tomografia sobre técnicas tradicionais para a caracterização da morfologia óssea e da 
interconectividade dos biomateriais, complementando as atuais técnicas histomorfométricas (JONES, 2004).

A estrutura porosa é composta por poros e interconexões entre poros, com uma complexa estrutura de rede tridimensional e muitos investigadores descreveram a relação entre o tamanho médio do poro e a quantidade de crescimento ósseo. No entanto, a influência da estrutura da rede de poros ou na conectividade entre os poros para crescimento interno de tecido foi raramente discutida. Otsuki et al. (2006) avaliaram quatro tipos de implantes porosos de titânio bioativo $(6 \mathrm{~mm}$ de diâmetro e $15 \mathrm{~mm}$ de comprimento), com diferentes tamanhos de poros e tipos de porosidade. A metodologia utilizou algoritmos específicos para análise 3D de interconexão com base na micro-CT. Essas amostras foram implantadas no côndilo femural de coelhos machos e a análise histomorfométrica foi realizada após 6 e 12 semanas. Este estudo revelou que poros pouco diferenciados tendem a ter gargantas de poros mais estreitas, especialmente nos seus acessos mais curtos para a periferia. Além disso, para a avaliação do implante como um todo, os autores propuseram novos índices, que representam o grau de crescimento interno de tecido e osso no implante considerando o efeito de gargantas de poros estreitas.

Efeoglu et al. (2009) avaliaram o potencial de regeneração óssea de três biomateriais compostos de uma matriz absorvível de policaprolactona, da matriz reforçada com fibras de biovidro $45 S 5$ e da matriz com fibras de fosfato. Os materiais foram implantados em defeitos de calvárias de ratos e analisados através da micro-CT. Os resultados mostraram que a matriz de policaprolactona com fibras de fosfato é promissora para aplicações na região craniomaxilofacial. Além disso, o estudo evidenciou que a micro-CT proporcionou uma caracterização da mineralização do osso e tem o um grande potencial de ser um indicador confiável de qualidade da cicatrização óssea.

Foi proposto por Polak et al. (2012) um trabalho que desenvolveu e validou um algoritmo de segmentação de imagem para micro-CT que de uma meneira precisa e eficiente segmenta o tecido ósseo dos biomateriais a base de fosfato de cálcio e do tecido mole. Esse algoritmo permite a avaliação quantitativa do crescimento ósseo no interior dos poros do biomaterial, o que outrora era muito difício devido a similaridade na atenuação de raios- $X$ para os dois materiais. $O$ algoritmo proposto explora a periodicidade de andaime e combina análise de sinais, 
detecção de bordas e conhecimento das relações tridimensionais entre o osso, 0 biomaterial e o tecido mole. Aplicação deste algoritmo pode levar a uma nova compreensão do papel da estrutura interna dos andaimes dos biomateriais nos padrões e taxas de crescimento ósseo.

Foram avaliadas imagens de micro e nano-CT para demonstrar e quantificar a neovascularização na integração óssea de um biomaterial, dando uma estimativa na resolução necessária para análise da angiogênese em um modelo de cura de defeito de $5 \mathrm{~mm}$ em fêmur de ratos preenchidos com compósitos de colágeno e sílica. Após 6 semanas, foram realizadas análises de micro-CT e nano-CT com resolução de 9 e $3 \mu \mathrm{m}$, respectivamente. Através dessas imagens em 3D, foram quantitativamente caracterizados os vasos sanguíneos recém-formados na área do biomaterial, a fração de volume total vascular, o volume do material reabsorvido e o volume da formação óssea. Os resultados foram complementados por histologia. Somente a nano-CT de alta resolução demonstrou formação de novos vasos sanguíneos em torno do biomaterial, no nível capilar. A imuno-histoquímica confirmou que os vasos sanguíneos em torno do material de substituição óssea foram recém-formados. Os autores concluíram que a nano-CT é viável para análise quantitativa de angiogênese durante a integração óssea dos biomateriais, sendo uma ferramenta promissora neste contexto para o futuro (ALT, 2011).

A micro-CT se mostra um método eficaz de reconstituição do osso e de biomateriais com alta resolução. Os eventos celulares que regem a regeneração óssea impulsionam os estudos empregando a análise histológica convencional. Nenhum trabalho até então comparou uma hidroxiapatita sintética e um compósito a base de colágeno bovino e fosfato de cálcio à uma marca comercial internacionalmente conhecida, como o Bio-Oss. Adicionalmente, a análise por microCT não foi empregada anteriormente com esses materiais, especialmente em defeitos críticos de calvária. Estudos com novos biomateriais e técnicas de avaliação mais precisas e menos invasivas se fazem necessárias para a melhoria dos materiais de substituição óssea. 


\section{OBJETIVOS}

Observando a existência de muitos tipos de substitutos ósseos, com diferentes características físico-químicas e comportamento biológico, há a necessidade de compará-los em relação ao padrão osteocondutor durante o processo de reparo ósseo.

O presente estudo tem por objetivo avaliar o potencial osteocondutor de materiais experimentais a base de hidroxiapatita sintética e tendão bovino mineralizado, comparando-os a marca comercial Bio-Oss ${ }^{\circledR}$.

Os materiais foram implantados em defeitos ósseos de tamanho crítico em calvária de ratos Wistar e, após 30 dias, avaliada a presença dos materiais e a quantidade de osso neoformado através de microtomografia computadorizada e análise histomorfométrica.

Como objetivo secundário, porém não menos importante, comparou-se os achados da microtomografia computadorizada aos da análise histológica, evidenciando se esses métodos são complementares ou se a microtomografia já poderia substituir a análise histológica convencional. 


\section{MATERIAIS E MÉTODOS}

A pesquisa foi aprovada pela Comissão de Ética em Experimentação Animal da Faculdade de Medicina de Ribeirão Preto da Universidade de São Paulo na reunião do dia 30 de março de 2009 (processo número 028/2009 - Anexo).

\subsection{MATERIAIS}

Os materiais experimentais utilizados nesse trabalho foram desenvolvidos no Laboratório de Bioquímica e Biomateriais do Instituto de Química São Carlos / USP sob supervisão da Dra. Virgínia Conceição Amaro Martins.

A hidroxiapatita foi sintetizada a partir de solução $1,00 \mathrm{Mol}^{-L^{-1}}$ de nitrato de cálcio tetrahidratado, $\mathrm{Ca}\left(\mathrm{NO}_{3}\right)_{2} \cdot 4 \mathrm{H}_{2} \mathrm{O}$, e solução $0,60 \mathrm{Mol}^{-\mathrm{L}^{-1}}$ de fosfato ácido de amônio, $\left(\mathrm{NH}_{4}\right)_{2} \mathrm{HPO}_{4}$, ajustando-se $\mathrm{opH}$ das soluções entre 11,0 e 12,0 com hidróxido de amônio concentrado. A síntese foi feita em atmosfera de nitrogênio. $O$ tamanho das partículas obtidas foi menor que 0,2 mm (BET, 1995 / Figura 6).

$O$ tendão bovino mineralizado foi obtido através do tratamento em solução alcalina contendo sais de $\mathrm{K}^{+}, \mathrm{Na}^{+}$e $\mathrm{Ca}^{2+}$ por um período de $96 \mathrm{~h}$ a $25^{\circ} \mathrm{C}$. Em seguida o tendão foi equilibrado em solução salina, lavado em $\mathrm{H}_{3} \mathrm{BO}_{3}$, EDTA e água. As matrizes resultantes foram então mineralizadas em solução de $\mathrm{CaCl}_{2} \quad 0,2$ mol.L-1 $\mathrm{pH}=7,4$ e de $\mathrm{Na}_{2} \mathrm{HPO}_{4}$ 0,12 mol. $\mathrm{L}^{-1} \mathrm{pH}=9$ durante $6 \mathrm{~h}$, ocorrendo a troca de soluções a cada 30 minutos e lavadas em água deionizada entre as trocas (KIRSCHBAUER, 2009). Após a mineralização as matrizes foram congeladas e liofilizadas (Figura 6).

Os materiais experimentais foram esterilizados por Óxido de Etileno pela empresa OXETIL INDÚSTRIA E COMÉRCIO DE PRODUTOS ESTERILIZADOS LTDA-EPP, sob supervisão da Dra. Rita Gisele Biffi Medeiros (CRF: 26.334).

O Bio-Oss é um biomaterial de enxertia óssea produzido pela Geistlich Pharma (Suíça) e é reconhecido internacionalmente pelas publicações e resultados alcançados (Figura 6). De acordo com o fabricante, o Bio-Oss é obtido a partir do osso bovino trabecular inorgânico e sua desproteinização ocorre à cerca de $300^{\circ} \mathrm{C}$. 

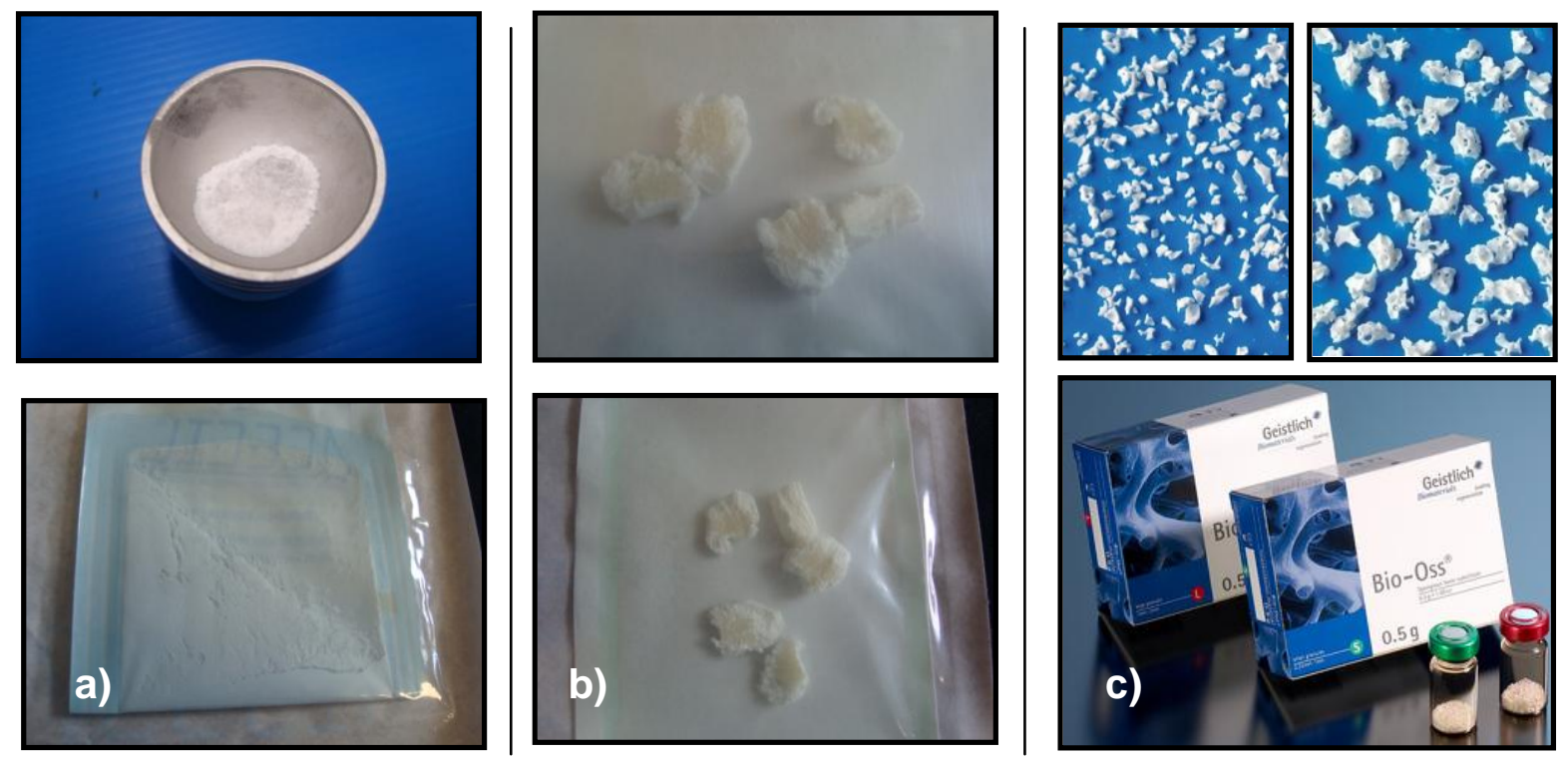

Figura 6 - Materiais empregados para preenchimento do defeito ósseo (imagens dos materiais fora e dentro dos invólucros): a) Hidroxiapatita Sintética; b) Tendão Bovino Mineralizado e c) Bio-Oss / Geistlich

\subsection{CARACTERIZAÇÃO DOS MATERIAIS}

O perfil termogravimétrico, calorimetria exploratória diferencial e determinação da topografia superficial através da microscopia eletrônica de varredura foram obtidos no Laboratório de Bioquímica do Instituto de Química de São Carlos sob supervisão da Dra. Virgínia Conceição Amaro Martins.

\subsubsection{Análise Termogravimétrica (TGA)}

A termogravimetria é uma técnica termoanalítica na qual a massa de substância é medida em função da temperatura, a medida que a amostra é submetida a uma programação controlada de temperatura. Uma pequena quantidade da amostra é colocada em um suporte de alumina, na qual sua massa é constantemente medida por uma termobalança. O tendão bovino mineralizado e não mineralizado foram submetido à análise temogravimétrica (TGA) em atmosfera de ar a $10^{\circ} \mathrm{C}$ min $^{-1}$ em equipamento TGA-2050 da TA Instruments visando determinar a porcentagem de mineralização do tendão. 


\subsubsection{Calorimetria Exploratória Diferencial (DSC)}

Nessa técnica mede-se a diferença de energia fornecida a uma substância em função da temperatura ou tempo. As medidas de calorimetria exploratória diferencial (DSC) foram empregadas para o acompanhamento da variação de massa e energia do material envolvida durante o processo de aquecimento do material, sob uma atmosfera dinâmica de $\operatorname{ar}\left(60 \mathrm{~mL} \mathrm{~min}^{-1}\right)$ em um aparelho TA Instruments DSC 2010.

\subsubsection{Microscopia Eletrônica de Varredura (MEV)}

A análise foi realizada para a verificação da morfologia dos materiais, através de amostras fixadas com fita adesiva de carbono em suporte próprio para MEV e submetidas à metalização em ouro, que consiste em recobrir as amostras com uma camada de aproximadamente $20 \mathrm{~nm}$. Foi operado com um feixe de elétrons $20 \mathrm{kV}$ e obteve-se fotomicrografias das matrizes nos aumentos de $100 \mathrm{e}$ 500X.

As fotomicrografias foram obtidas por meio de um equipamento LEO 440 da LEO Electron Microscopy, com um detector Oxford da Oxford Instruments. As imagens do Bio-Oss foram cortesia do Dr. Luis Marcelo Calderero, Departamento Científico da Geistlich Pharma do Brasil.

\subsection{AVALIAÇÃO BIOLÓGICA}

O procedimento animal realizou-se no Biotério da Bioengenharia EESC/USP sob supervisão do MSc Nelson Ferreira da Silva Júnior.

Ratos Wistar adultos com aproximadamente $200 \mathrm{~g}$ de peso foram divididos nos seguintes grupos, sendo que cada grupo tinha cinco animais: 
1- Bio-Oss: Composto por cinco animais, nos quais foram realizados os procedimentos cirúrgicos, preenchimento da lesão com Bio-Oss e análise radiográfica e morfológica após 30 dias;

2- HA: Composto por cinco animais, nos quais foram realizados os procedimentos cirúrgicos, preenchimento da lesão com Hidroxiapatita Sintética e análise radiográfica e morfológica após 30 dias;

3- Tendão: Composto por cinco animais, nos quais foram realizados os procedimentos cirúrgicos, preenchimento da lesão com Tendão Bovino Mineralizado e análise radigráfica e morfológica após 30 dias;

4- Controle: Composto por um animal, no qual foi realizado o procedimento cirúrgico, preenchimento da lesão com coágulo e análise radiográfica e morfológica após 30 dias;

5- Íntegro: Composto por um animal que não sofreu intervenção cirúrgica, análise radiográfica e morfológica após 30 dias;

\subsubsection{Reparo em defeito crítico de calvária}

As cirurgias foram realizadas com os animais sob anestesia geral obtida com injeção intramuscular de cloridrato de cetamina (Ketalar injetável - Achë Laboratórios Farmacêuticos S.A.) na dosagem de $75 \mathrm{mg} / \mathrm{kg}$ de massa corporal e relaxante muscular e sedativo de uso animal Ropun (Bayer S.A.) na dosagem de 1,5 $\mathrm{ml} / \mathrm{kg}$ (Figura 7).

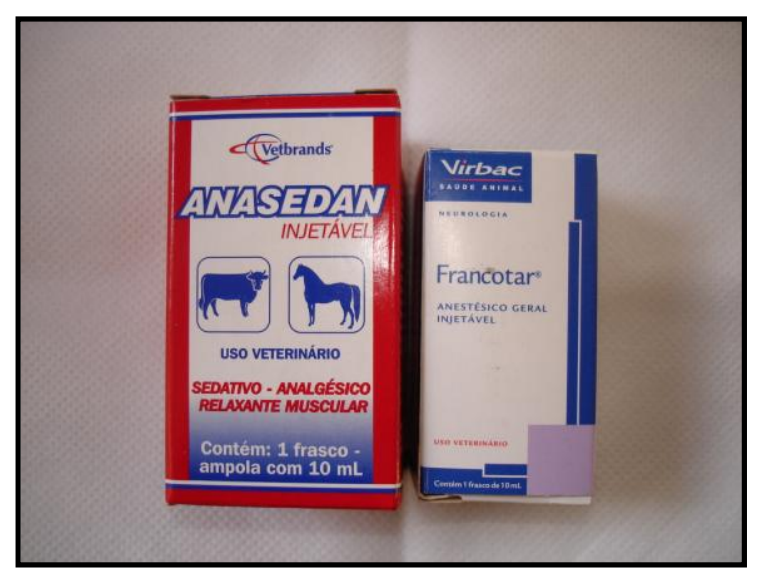

Figura 7- Relaxante muscular (Cloridrato de Xilazina - Anasedan®) e Anestésico Geral (Cloridrato de Ketamina - Flancotar ${ }^{\circledR}$ ) 
Após a tricotomia da região fronto-parietal da cabeça do animal, assepsia vigorosa com lodo Povidine e anestesia infiltrativa local com xilocaína a $2 \%$ contendo norepinefrina 1:50.000 (Merrell Lepetit Farmacêutica e Industrial Ltda), foi realizada uma incisão semi-lunar de espessura total com lâmina no15 no tegumento de revestimento do crânio, descolamento de retalho e exposição da superfície óssea da região.

Em seguida, com uma broca trefina ("serra-copo") cirúrgica de $8 \mathrm{~mm}$ de diâmetro, irrigação abundante e contínua com solução fisiológica, foi feita uma perfuração de $8 \mathrm{~mm}$ de diâmetro na região fronto-parietal, transpassando toda espessura óssea da díploe e expondo as meninges do fundo da lesão (Figura 8).

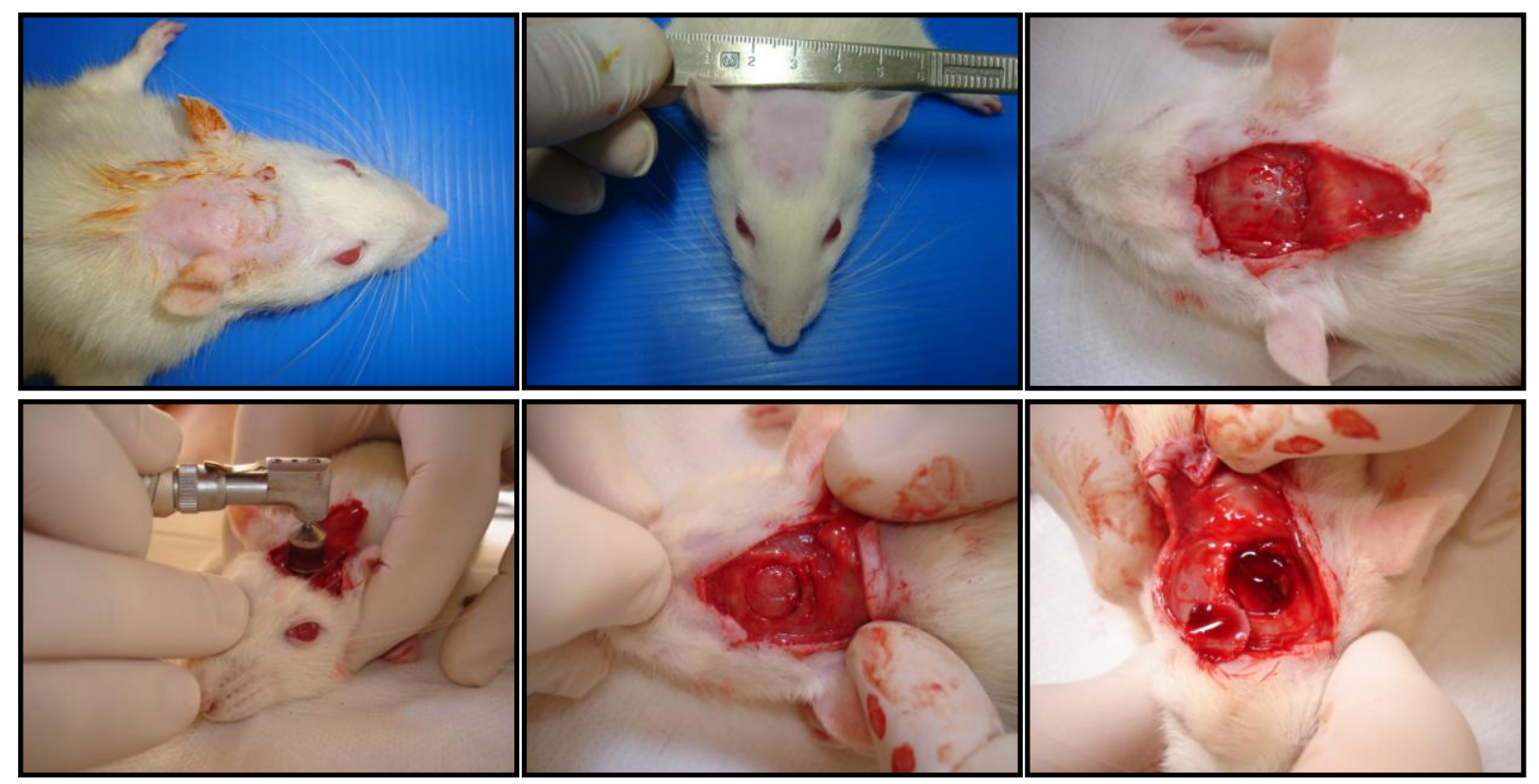

Figura 8 - Procedimento Cirúrgico: assepsia do campo operatório com lodo Povidine, tricotomia da região fronto-parietal, incisão do tegumento, descolamento total do periósteo expondo o tecido ósseo do crânio e trepanação com emprego de broca trefina de $8 \mathrm{~mm}$ de diâmetro. Aspecto do defeito ósseo bicortical e exposição de duramáter

A seguir a lesão foi preenchida conforme o grupo de tratamento (Figura 9) e, em seguida, o retalho foi colocado em posição e suturando com linha de seda preta no3 (Ethicon - Johnson \& Johnson). 

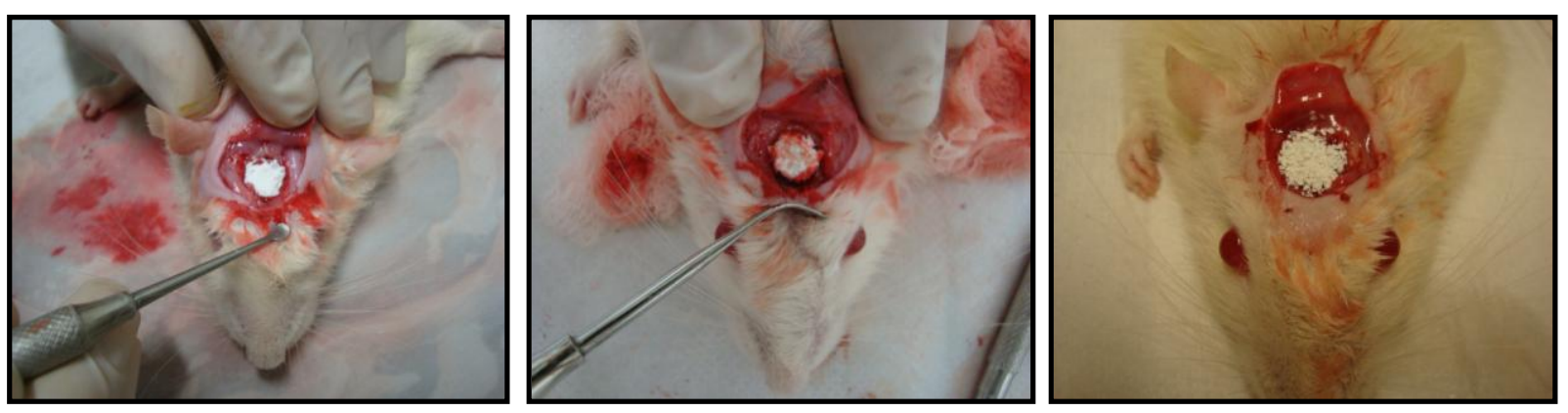

Figura 9 - Preenchimento da cavidade óssea com os materiais: hidroxiapatita sintética, tendão bovino mineralizado e Bio-Oss, respectivamente

Por todo o período do experimento (30 dias) os animais permaneceram nas dependências do biotério da Bioengenharia - São Carlos - Universidade de São Paulo, recebendo dieta composta de ração e água ad libitum.

Os animais dos grupos experimentais foram sacrificados por sobre dosagem de cloridrato de cetamina (Ketalar injetável - Achë Laboratórios Farmacêuticos S.A.) de 30 dias após a cirurgia. Imediatamente as suas calotas cranianas foram dissecadas, acondicionadas em frascos individuais, identificadas e fixadas em formol $10 \%$, em tampão fosfato $\mathrm{pH} \mathrm{7,2} \mathrm{durante} \mathrm{sete} \mathrm{dias.}$

\subsubsection{Análise histológica e Micro-CT}

O processamento histológico foi realizado no Laboratório de Morfologia da Faculdade de Odontologia de Araraquara-UNESP.

As aquisições de imagens radiográficas foram realizadas através da microtomografia computadorizada em parceria com o CNPDIA da Embrapa de São Carlos (microtomógrafo SkyScan 100kV - 100 $\mathrm{A}$ ).

As amostras foram posicionadas e fixadas à sela do aparelho, de maneira que não se movimentassem durante o experimento. Qualquer movimento inviabiliza a aquisição das imagens. O aparelho foi ajustado à uma resolução de $2000 \times 2000$ pixels e cortes com $16 \mu \mathrm{m}$ de espessura. O tempo de aquisição das imagens foi de aproximadamente duas horas por amostra (Figura 10). 

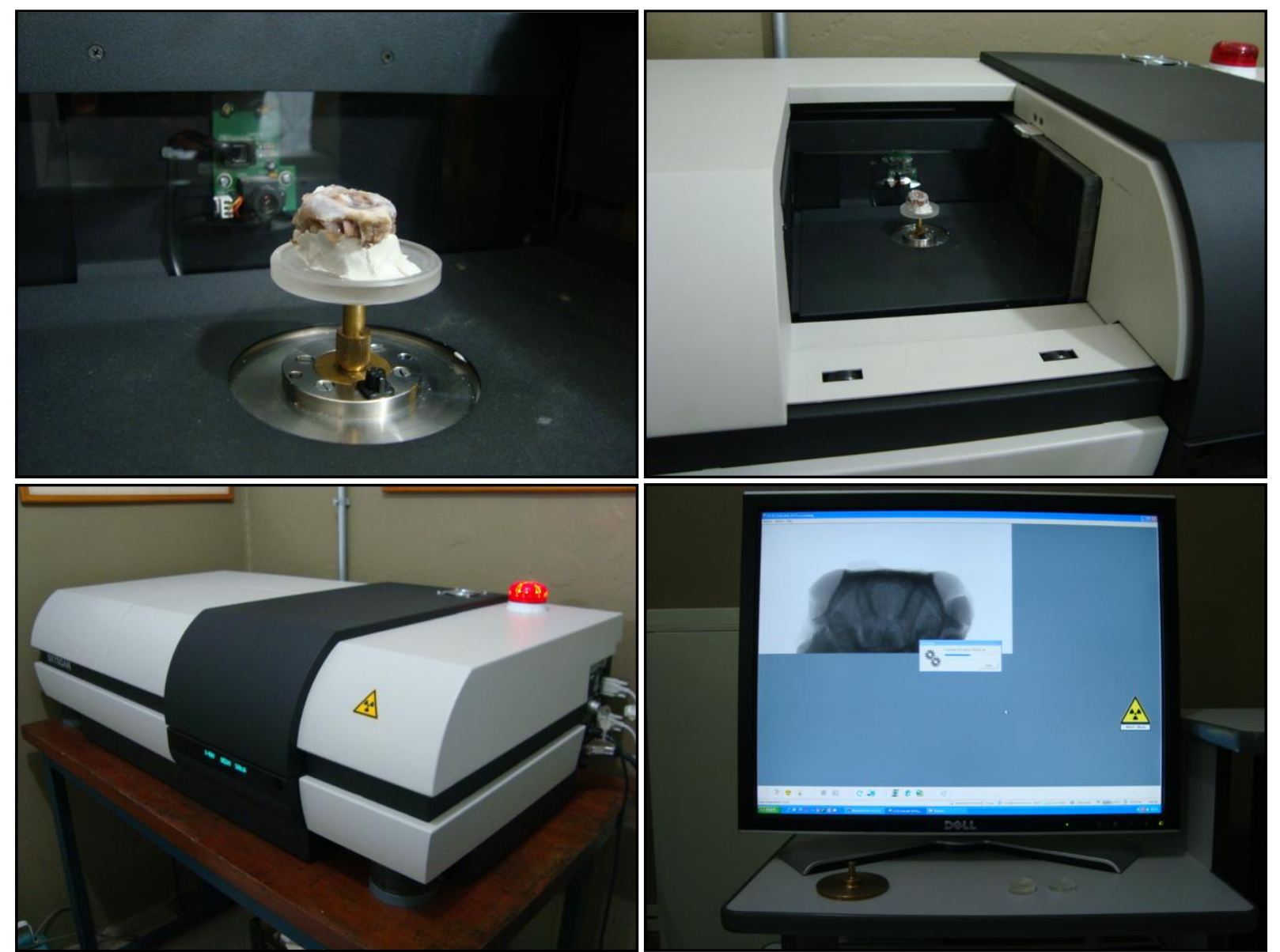

Figura 10 - Microtomógrafo SkyScan 100 kV - $100 \mu \mathrm{A}$. Crânio posicionado no dispositivo de fixação e aparelho em funcionamento adquirindo as imagens através de Raios- $X$

As imagens foram analisadas e reconstituídas em duas e três dimensões quantificando-se o tecido ósseo neoformado utilizando-se o Sofware CTAnalyser Version: 1.9.1.0.@ 2003-08 SkyScan (Figura 11). 


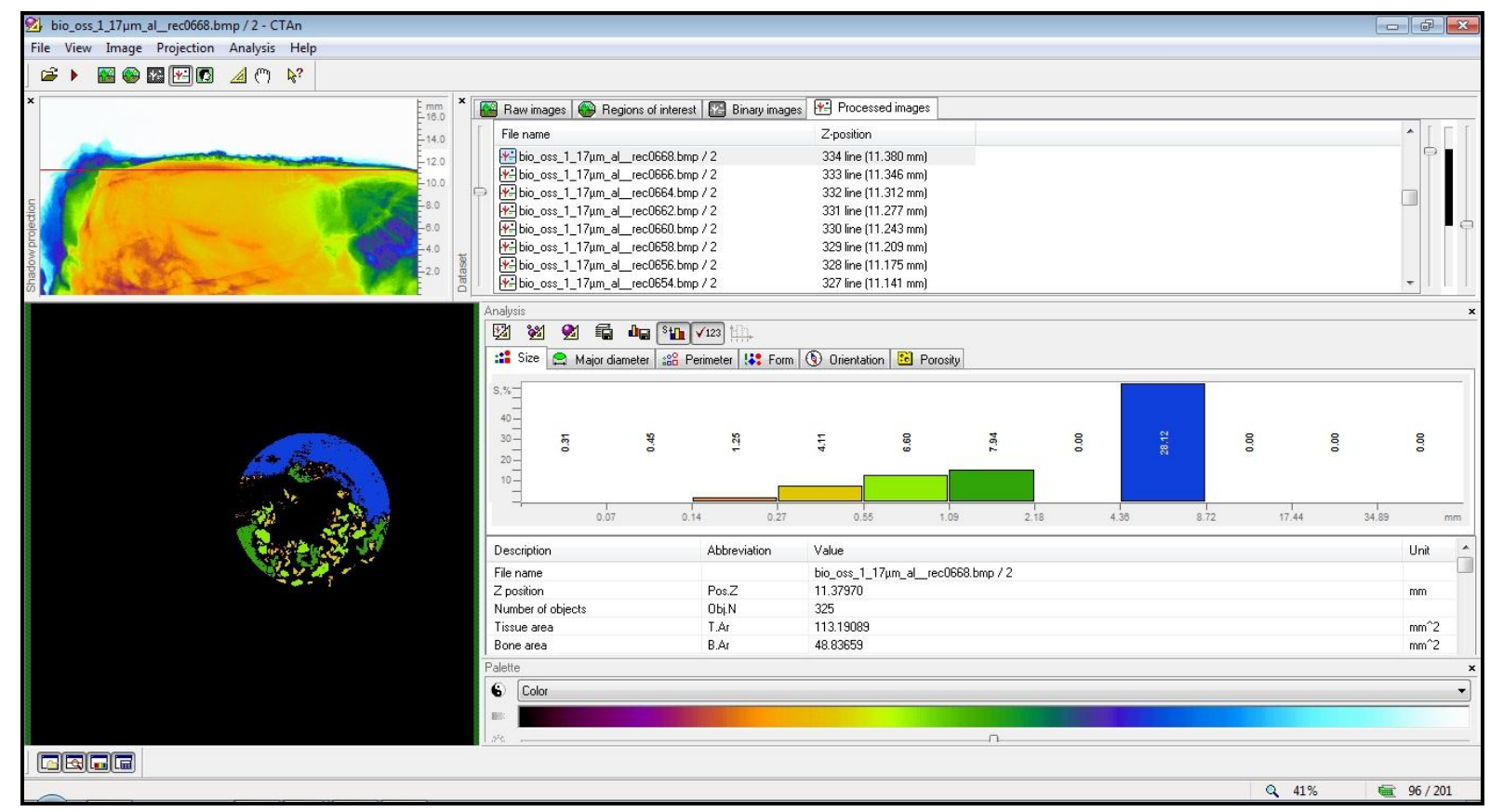

Figura 11 - Tela de trabalho do Sofware CTAnalyser ilustrando o desenvolvimento das etapas para reconstituição das imagens em 3D e quantificação dos resultados

Após as imagens radiográficas serem adquiridas, uma região de interesse circular de $8 \mathrm{~mm}$ de diâmetro e com uma espessura que compreendesse a díploe ósseo da calvária foi selecionada para análise. Essa região de interesse tinha $8 \mathrm{~mm}$ para garantir a análise somente dos eventos da regeneração óssea do interior do defeito crítico que fora criado.

Para a análise da imagem em 3D, o primeiro passo é o ajuste fino da escala de cinza (gray threshold). O valor de cinza de uma imagem é proporcional ao coeficiente de atenuação linear do tecido. A escala dos valores de cinza no programa de análise varia de 0 a 255. No estudo foi utilizado um menor valor de cinza de 90 e um maior valor de cinza de 250. Dessa maneira era possível diferenciar o tecido duro mineralizado do tecido mole, especialmente dentro do defeito crítico de $8 \mathrm{~mm}$ (Figura 12). 


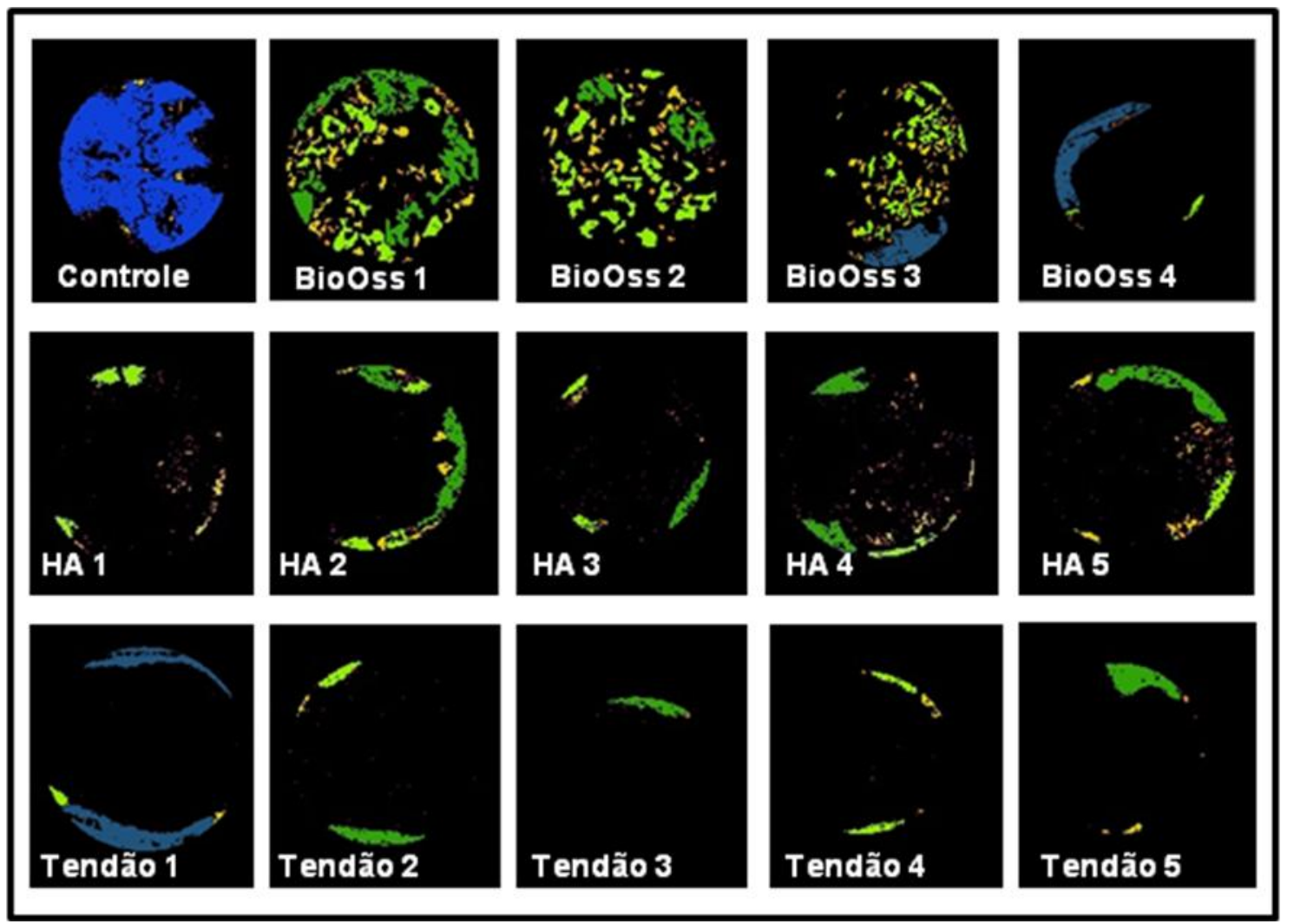

Figura 12 - Reconstituição do tecido mineralizado da área interna do defeito ósseo. Notar o tecido mineralizado em cores e o tecido mole em negro (diâmetro de $8 \mathrm{~mm}$ )

A análise morfométrica quantitativa do tecido dentro do defeito ósseo foi conduzida em voxels correspondentes ao tecido mineralizado o que excluía o tecido mole não mineralizado. Imagens em 3D foram reconstituídas para cada amostra e os seguintes parâmetros morfométricos foram obtidos.

- VOLUME DO TECIDO ÓSSEO: quantidade de tecido mineralizado presente no interior do defeito $\left(\mathrm{BV} ; \mathrm{mm}^{3}\right)$;

- PORCENTAGEM DE TECIDO ÓSSEO : razão do volume tecido mineralizado pelo total do volume analisado (BV/TV; \%);

- SUPERFÍ́CIE DE CONTATO ÓSSEO: área de superfície do tecido mineralizado que se encontra interconectado $\left(\mathrm{mm}^{2}\right)$;

- DENSIDADE DE SUPERFÍCIE ÓSSEA: razão da área total da superfície do tecido mineralizado pelo volume total analisado (BS/TV).

Em seguida, as peças foram submetidas à descalcificação em líquido de MORSE (ácido fórmico à 50\% + citrato de sódio à 10\%, 1:1), por um período de 
trinta dias. Após processamento histológico estandardizado, as peças foram incluídas em Histosec (parafina + resina sintética), sendo orientadas para obtenção de cortes histológicos no sentido latero-lateral. Cortes semi-seriados de $5 \mu \mathrm{m}$ de espessura foram obtidos e corados pela técnica da Hematoxilina - Eosina (HE).

Os cortes lâminas foram avaliadas e fotografadas em um Microscópio Leica Leitz DM RX com sistema de análise de imagem acoplada. $\mathrm{Na}$ análise histomorfométrica foram observados os seguintes aspectos da reação tecidual:

- TECIDO ÓSSEO NEOFORMADO: Presença de tecido ósseo jovem formado na área do defeito, principalmente nas margens;

- REMANECENTE DE BIOMATERIAL: Presença de partículas de biomaterial no interior do defeito denotando a taxa de reabsorção;

- NEOVASCULARIZAÇÃO: Presença de capilares sanguíneos ao redor do biomaterial e no interior do defeito;

- TECIDO CONJUNTIVO: Presença de tecido conjuntivo no interior do defeito;

- CÉlULAS OSTEOBLÁSTICAS: Presença de células formadoras de tecido ósseo como osteoblastos, osteócitos e células remodeladoras como osteoclastos.

Para a análise histológica, os parâmetros teciduais analisados receberam um escalonamento semi-quantitativo de acordo com os seguintes critérios:

(0) nenhum ; (1) mínimo ; (2) moderado ; (3) bem estabelecido e (4) intenso.

\subsection{Análise Estatística}

Para a comparação entre os materiais nas avaliações de micro-CT primeiramente verificou-se que os grupos tinham distribuição normal pelo teste de Kolmogorov-Smirnov. Posteriormente, para cada medida, foi executado Análise de Variância a um critério modelo fixo e, quando esta indicou haver diferença estatisticamente significante foi utilizado o teste post-hoc de Tukey para as comparações múltiplas. 
Para a comparação entre os materiais na avaliação histológica convencional primeiramente verificou-se que os grupos não tinham distribuição normal pelo teste de Kolmogorov-Smirnov. Posteriormente, para cada medida, foi executado o Teste de Kruskal-Wallis e, quando este indicou haver diferença estatisticamente significante foi utilizado o teste post-hoc de Dunn para as comparações múltiplas.

Para verificar a correlação entre as medidas de micro-CT e as medidas da avaliação histológica convencional utilizou-se o Coeficiente de Correlação de Spearman.

Em todos os testes estatísticos foi adotado nível de significância de $5 \%$ $(p<0,05)$. 


\section{RESULTADOS}

\subsection{CARACTERIZAÇÃO DOS MATERIAIS}

\subsubsection{Análise termogravimétrica}

A análise demonstrou que a matriz mineralizada possui uma quantidade de resíduo de $60,9 \%$ a uma temperatura de $750^{\circ} \mathrm{C}$ (Figura 13). Esse resíduo provém do material inorgânico depositado no tendão.

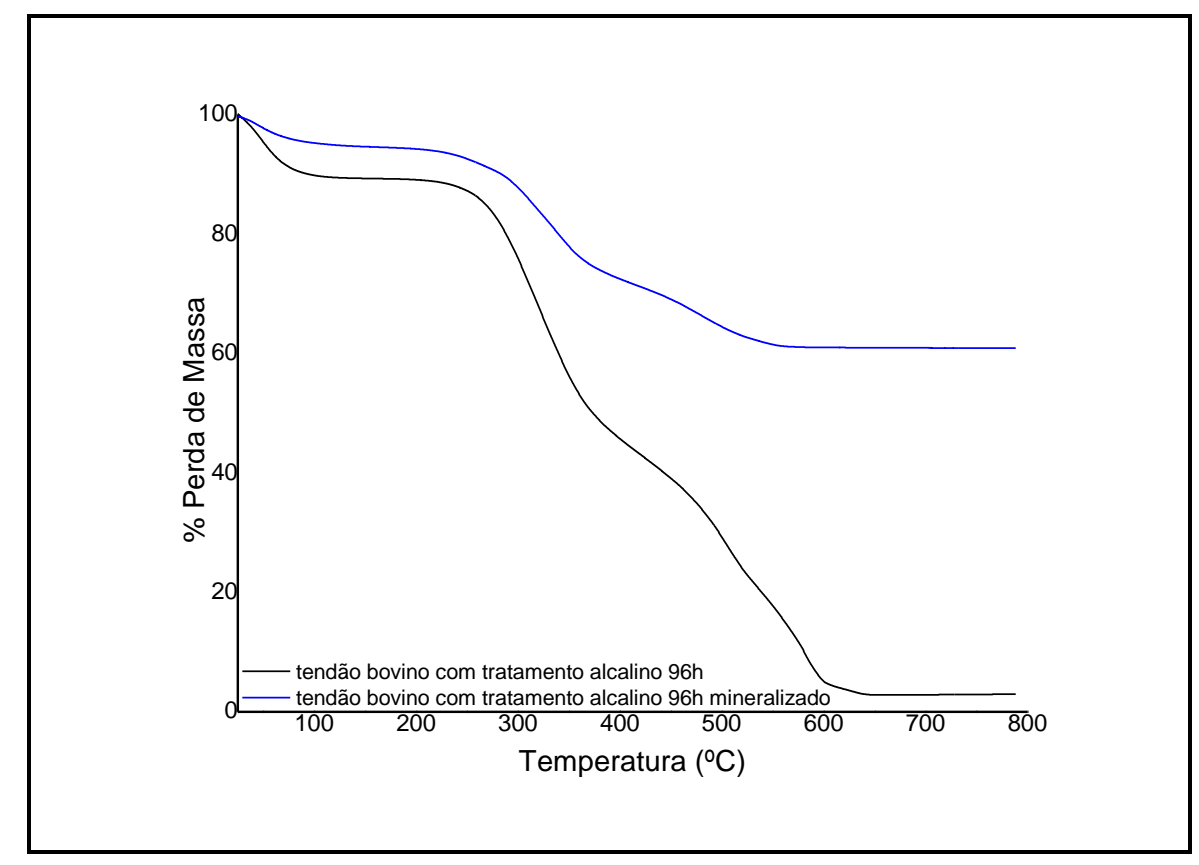

Figura 13 - Curvas termogravimétricas para o tendão bovino mineralizado e não mineralizado $\left(\operatorname{ar} 10^{\circ} \mathrm{C} \mathrm{min}^{-1}\right)$ 


\subsubsection{Calorimetria Exploratória Diferencial}

As temperaturas de desnaturação (Td) faram: $46,7^{\circ} \mathrm{C}$ para o tendão bovino, $59,0^{\circ} \mathrm{C}$ para o tendão bovino mineralizado e $56,1^{\circ} \mathrm{C}$ para o tendão bovino mineralizado e esterilizado (Figura 14).

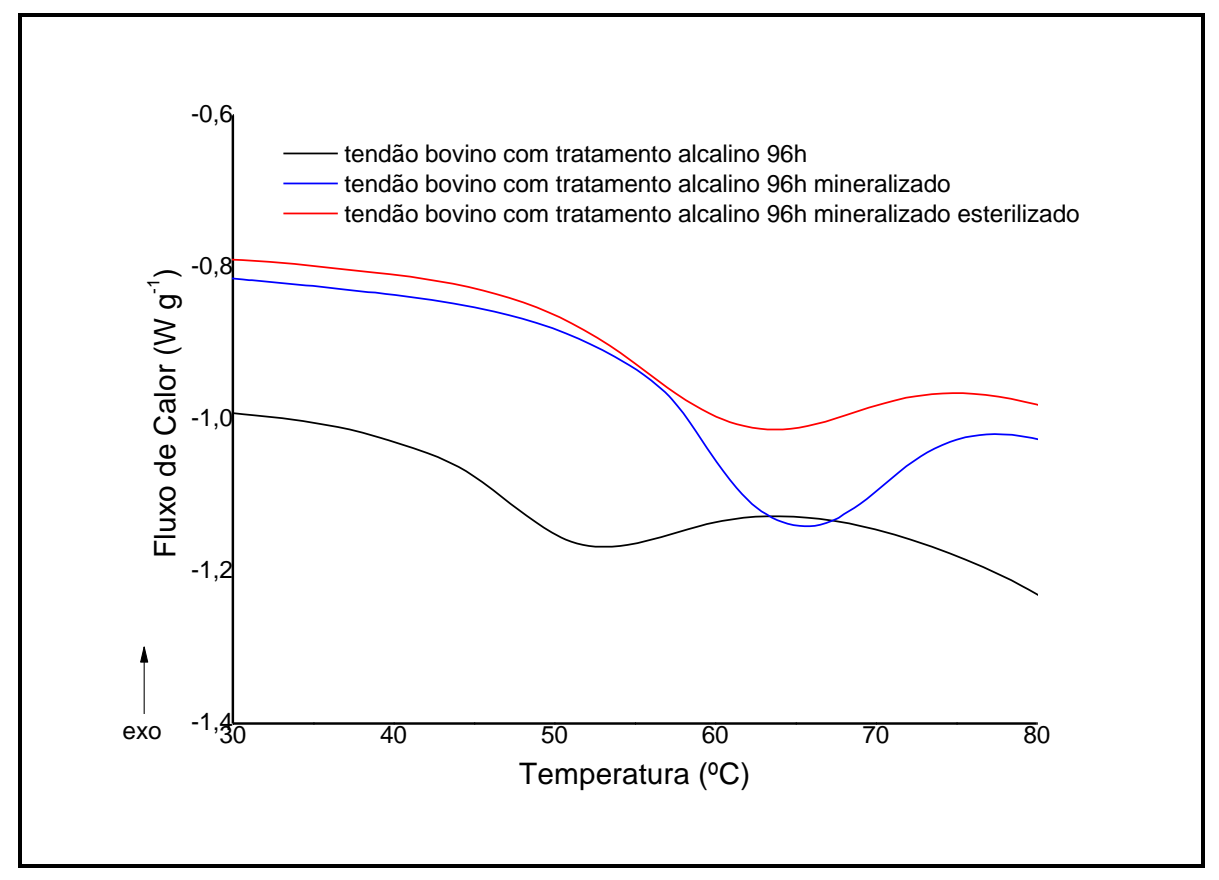

Figura 14 - Curvas DSC para tendão bovino, tendão bovino mineralizado e tendão bovino mineralizado e esterelizado

\subsubsection{Microscopia Eletrônica de Varredura}

Os resultados estruturais da superfície e da secção transversal do tendão bovino mineralizado, obtidos a partir da microscopia eletrônica de varredura, estão ilustrados nas figuras 15 e 16, respectivamente.

Pode-se observar a presença de inúmeros grânulos minerais depositados sobre a matriz orgânica. O material apresenta superfície irregular com poros que favorecerão o repovoamento celular. 


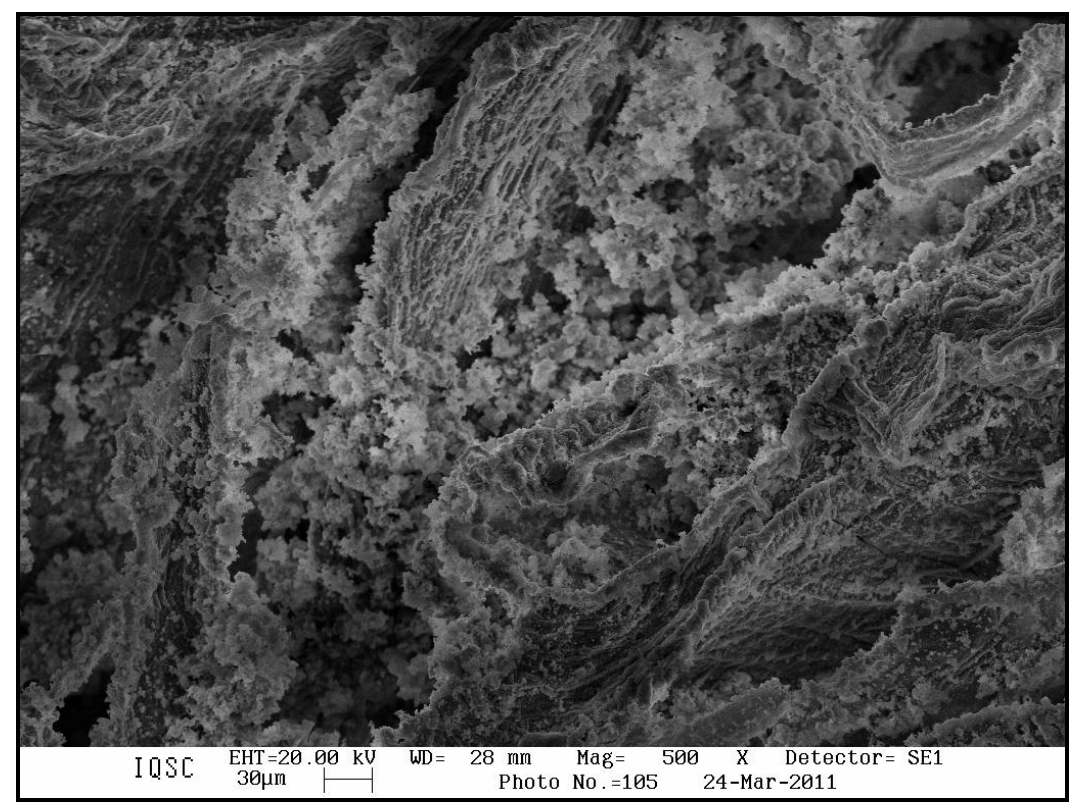

Figura 15 - Micrografia de MEV da superfície do tendão bovino mineralizado (aumento 500x)

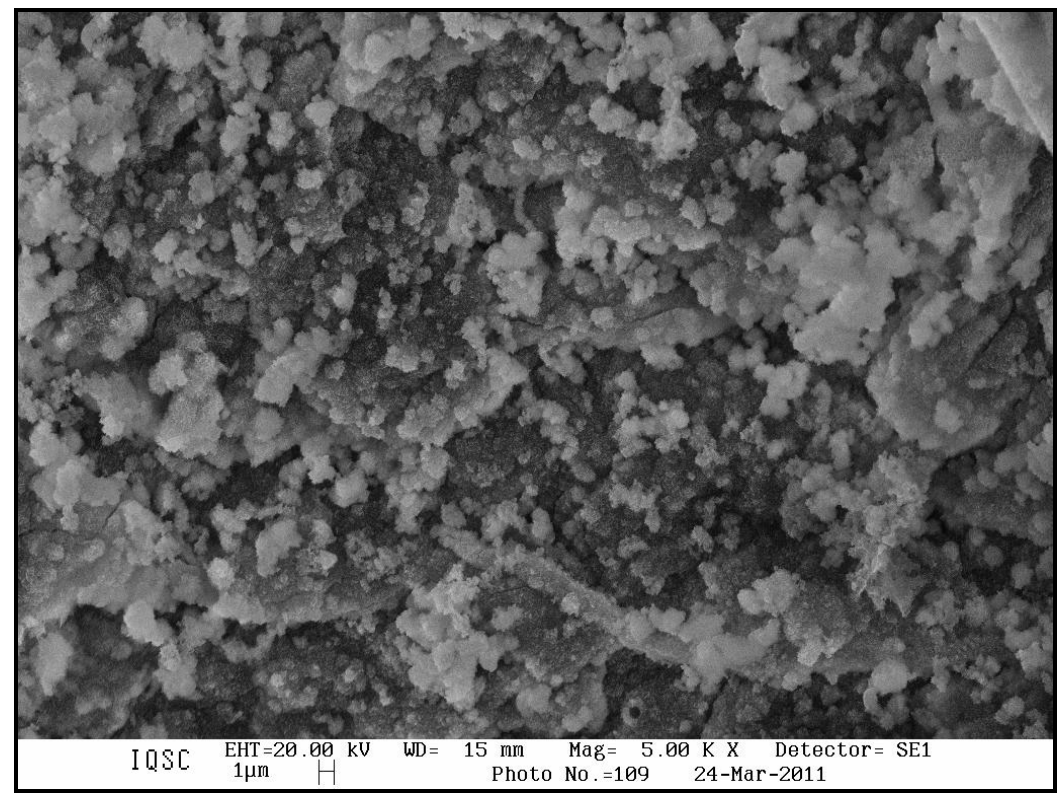

Figura 16 - Micrografia de MEV da superfície do tendão bovino mineralizado (aumento 5000x)

As imagens de MEV do Bio-Oss mostram um material altamente poroso que permitem o crescimento celular e vascular no seu interior. As trabéculas fornecem o arcabouço para a condução e manutenção do espaço para o crescimento ósseo (Figuras 17 e 18). 


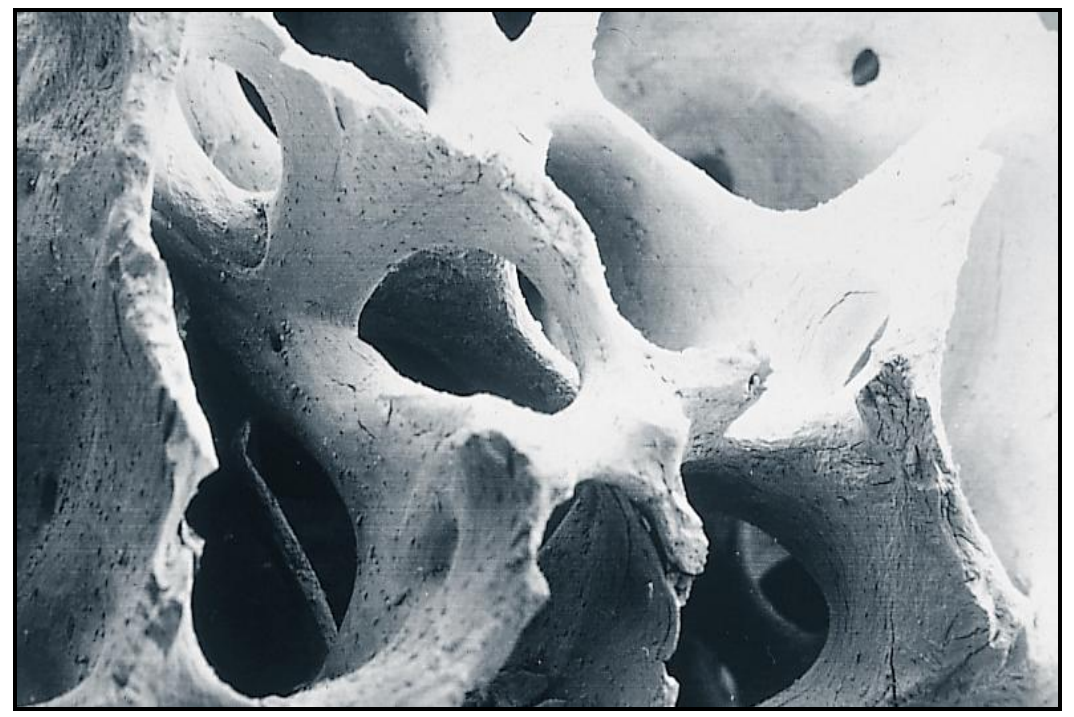

Figura 17 - Micrografia de MEV da secção transversal do Bio-Oss (aumento 50x)

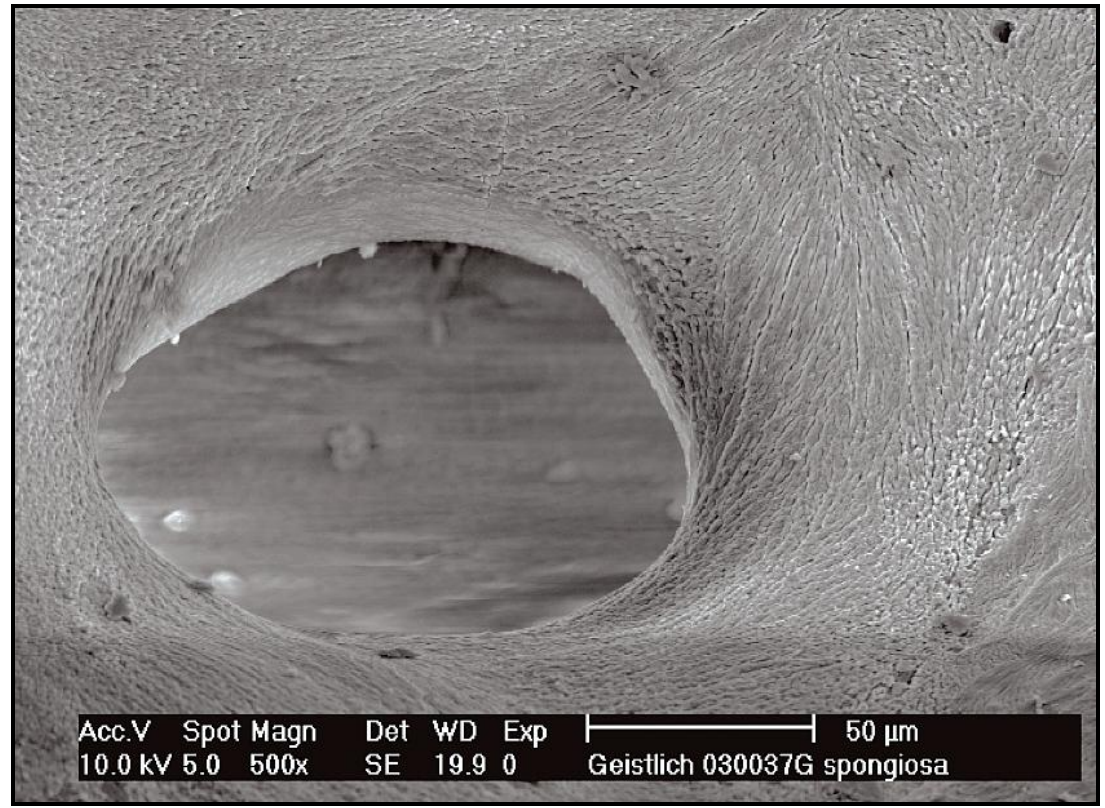

Figura 18 - Micrografia de MEV da secção transversal do Geistlich Bio-Oss (aumento 500x)

A análise por microscopia eletrônica de varredura é uma técnica bastante utilizada na caracterização dos substitutos ósseos. Através dela pode-se observar a topografia superficial dos biomateriais, especialmente em relação ao aspecto microscópico, tamanho dos grânulos e porosidade, como podemos observar nas figuras $15-18$. 


\subsection{AVALIAÇÃO BIOLÓGICA}

No presente experimento, todas os animais mostraram excelente recuperação nos dias subseqüentes a cirurgia, não necessitando em nenhum dos casos de utilização de antiinflamatórios e/ou antibióticos.

No grupo integro, onde os animais não foram submetidos à cirurgia, apenas a avaliação através da micro-CT, observou-se imagens em três dimensões da anatomia craniana do animal com grande riqueza de detalhes, evidenciando a boa resolução do aparelho e sensibilidade da metodologia (Figura 19).
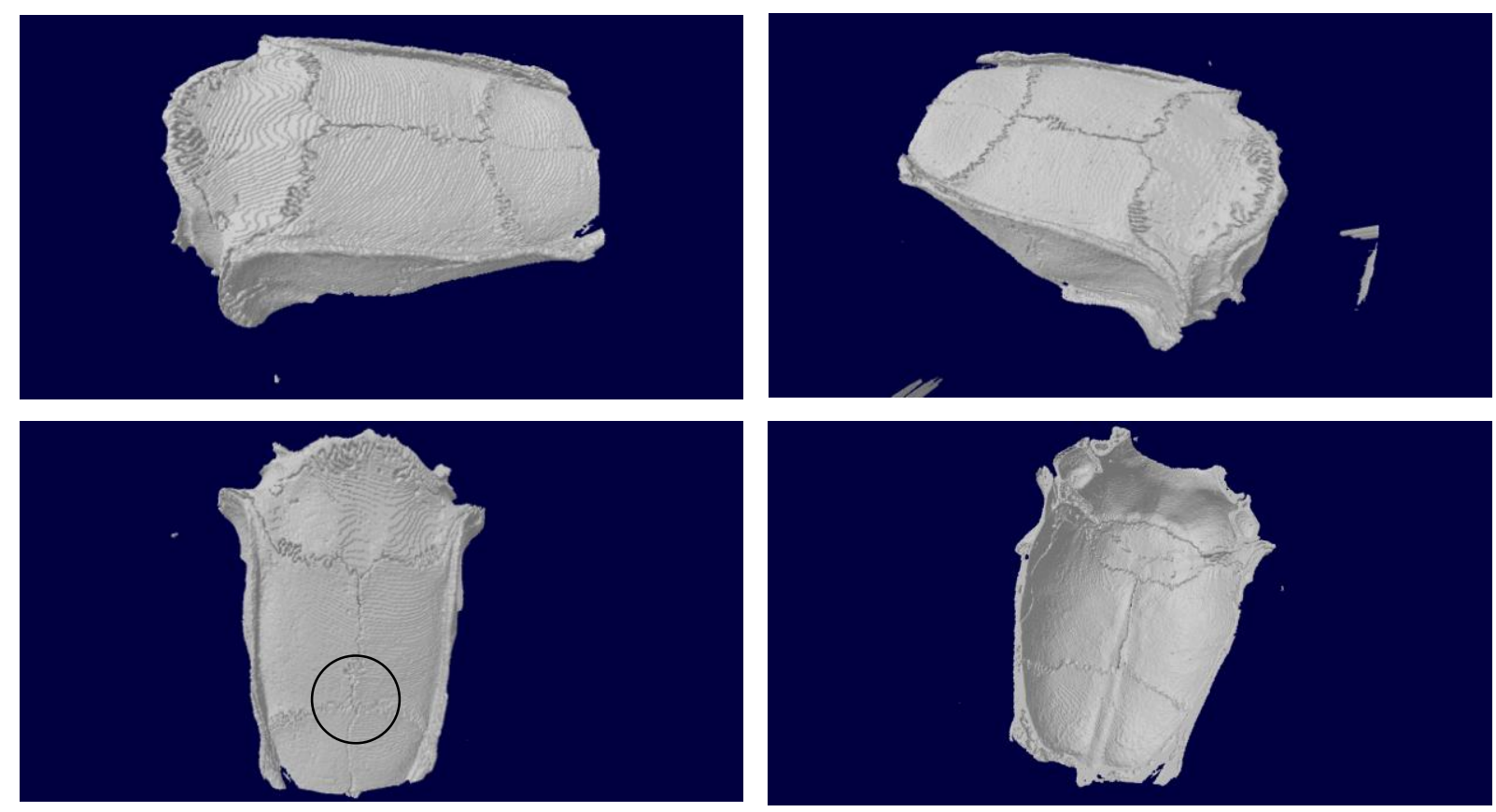

Figura 19 - Imagens em três dimensões obtidas a partir de microtomografia computadorizada: anatomia craniana do rato Wistar controle íntegro. Observar sutura óssea fronto-parietal onde foi realizado o defeito

No grupo controle, no qual não foi empregado material de enxertia, apenas o coágulo sanguíneo, foi observada a persistência do defeito ósseo criado no momento da cirurgia com ausência de formação de novo tecido ósseo. Esse grupo teve por objetivo mostrar que esse tipo de defeito não tem a capacidade de regenerar-se espontaneamente sem a utilização de terapias regeneradoras. Note que o defeito circular de $8 \mathrm{~mm}$ permanece quase inalterado, apresentando apenas um levíssimo contorno irregular (Figura 20). 


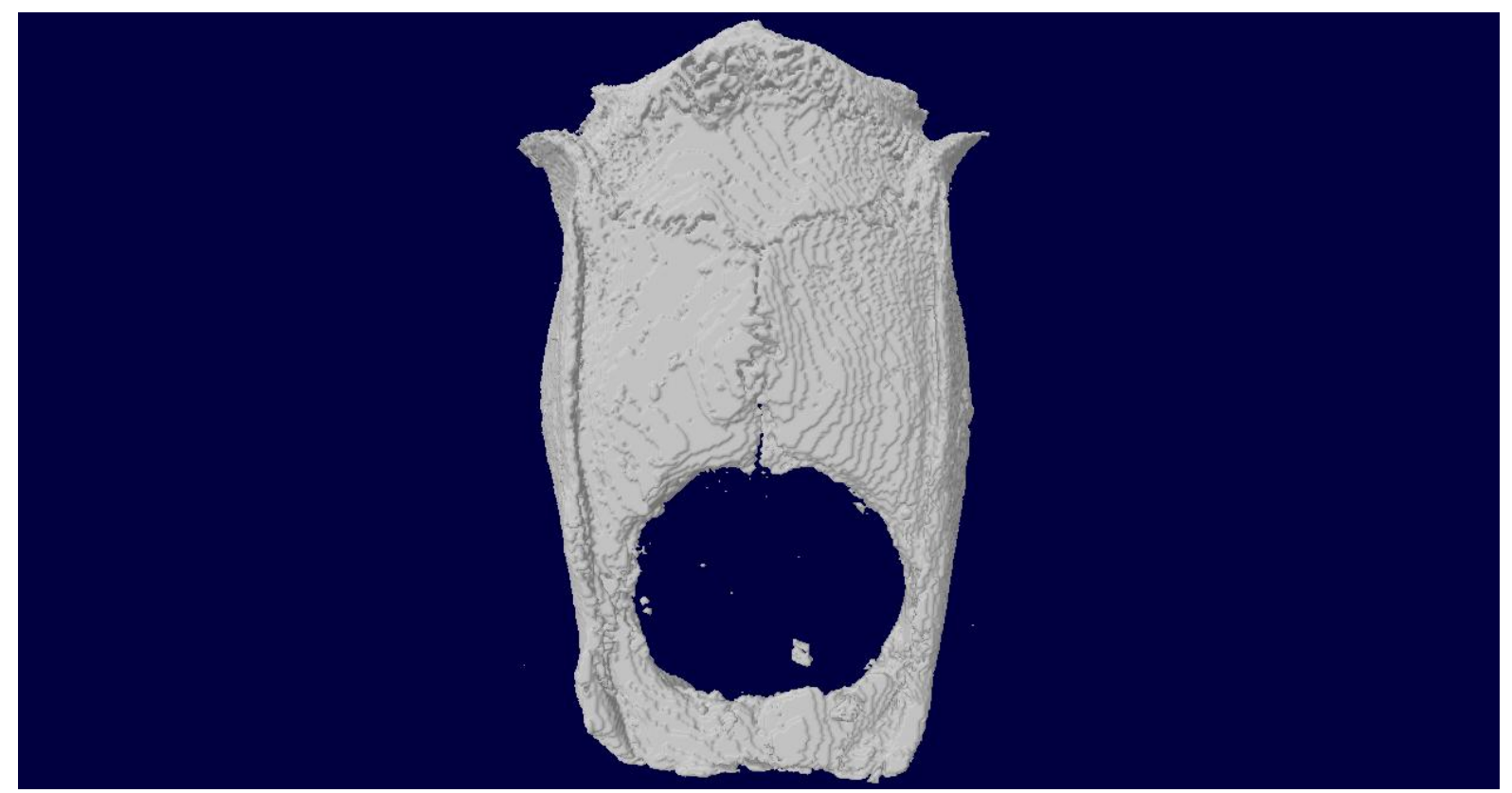

Figura 20 - Imagem em três dimensões do controle da cirurgia sem enxerto após 30 dias

Nos grupos experimentais do tendão bovino e da hidroxiapatita sintética observamos um mês após a cirurgia, em todos os casos, uma intensa reabsorção dos biomateriais e discreta formação de tecido mineralizado quando avaliamos as imagens da micro-CT (Figuras 21 e 22). Acredita-se que o espaço do defeito fora preenchido com tecido conjuntivo.

Observar também, na figura 21, o fechamento centrípeto da ferida cirúrgica com margens bastante irregulares, denotando a neoformação óssea. Note também a presença de pontos brancos flutuando no interior do defeito, os quais são imagens do remanescente de hidroxiapatita que já foi quase totalmente reabsorvida. As bordas laterais do defeito ósseo apresentavam aspecto biselado indicando início do processo de neoformação óssea. Em nenhum dos animais se observou resposta inflamatória exacerbada com reabsorção óssea intensa o que contra indicaria o emprego desses materiais. 

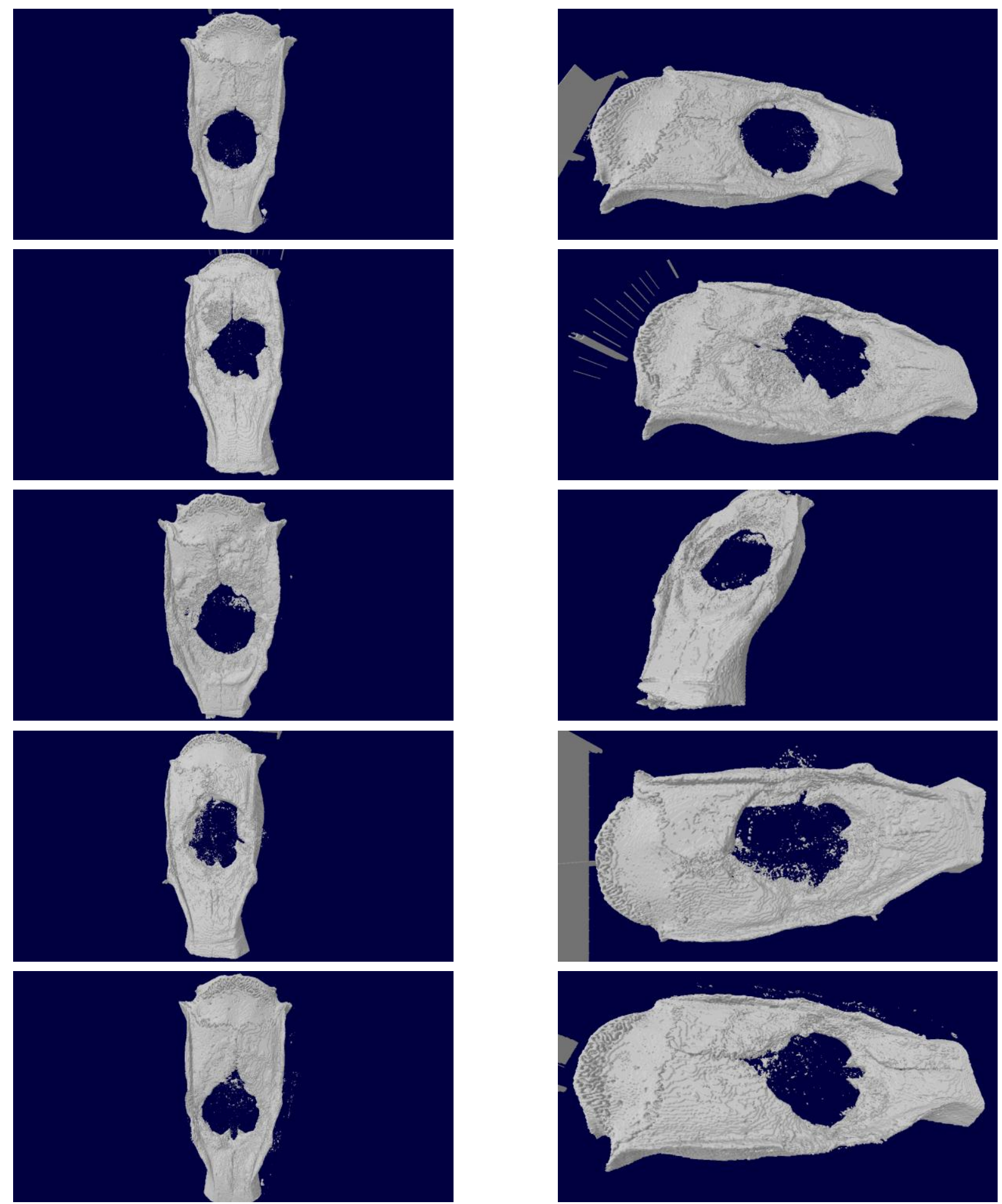

Figura 21 - Imagens em três dimensões do reparo ósseo dos sítios enxertados com hidroxiapatita sintética após 30 dias de cicatrização ( $n=5$ animais, vista superior e lateral)

Nota-se na figura 22 o fechamento da ferida cirúrgica com margens irregulares, denotando o processo de reabsorção (concavidade) e neoformação óssea (prolongamentos). O tendão mineralizado foi quase totalmente reabsorvido. 

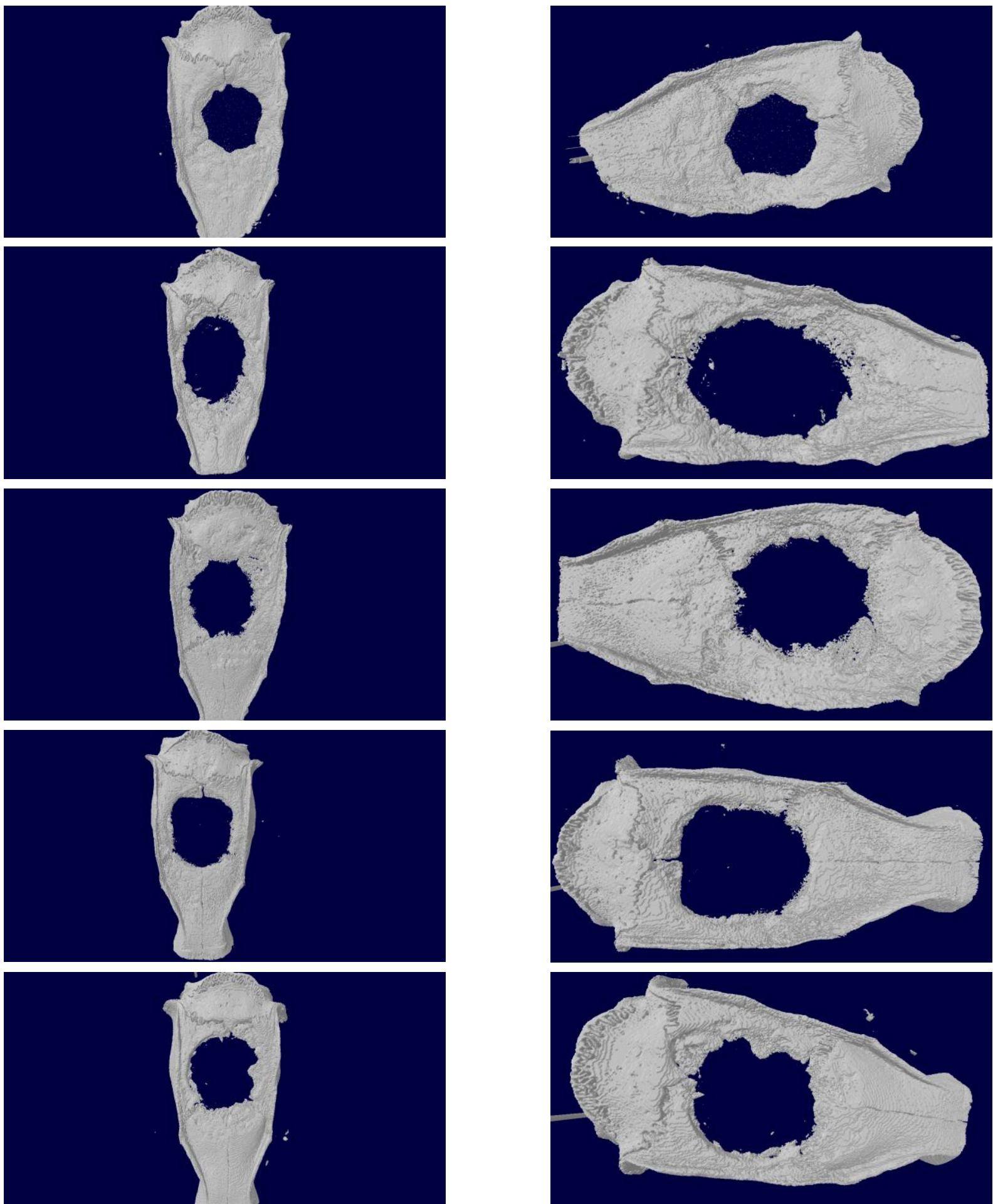

Figura 22 - Imagens em três dimensões do reparo ósseo dos sítios enxertados com tendão bovino mineralizado após 30 dias de cicatrização ( $\mathrm{n}=5$ animais, vista superior e lateral)

$\mathrm{Na}$ figura 23 pode-se observar o fechamento significante da ferida cirúrgica nos três primeiros animais. O enxerto é lentamente reabsorvido provendo, assim, um 
arcabouço para o crescimento tecidual no seu interior e formação de novo tecido ósseo. Há muitos grânulos de Bio-Oss no interior do defeito que ainda não foram reabsorvidos. O último animal apresentou reação tecidual desfavorável com eliminação do enxerto, processo de reabsorção óssea moderada da margem da ferida e pouca neoformação óssea. Um animal desse grupo apresentou complicações pós-operatórias e faleceu.
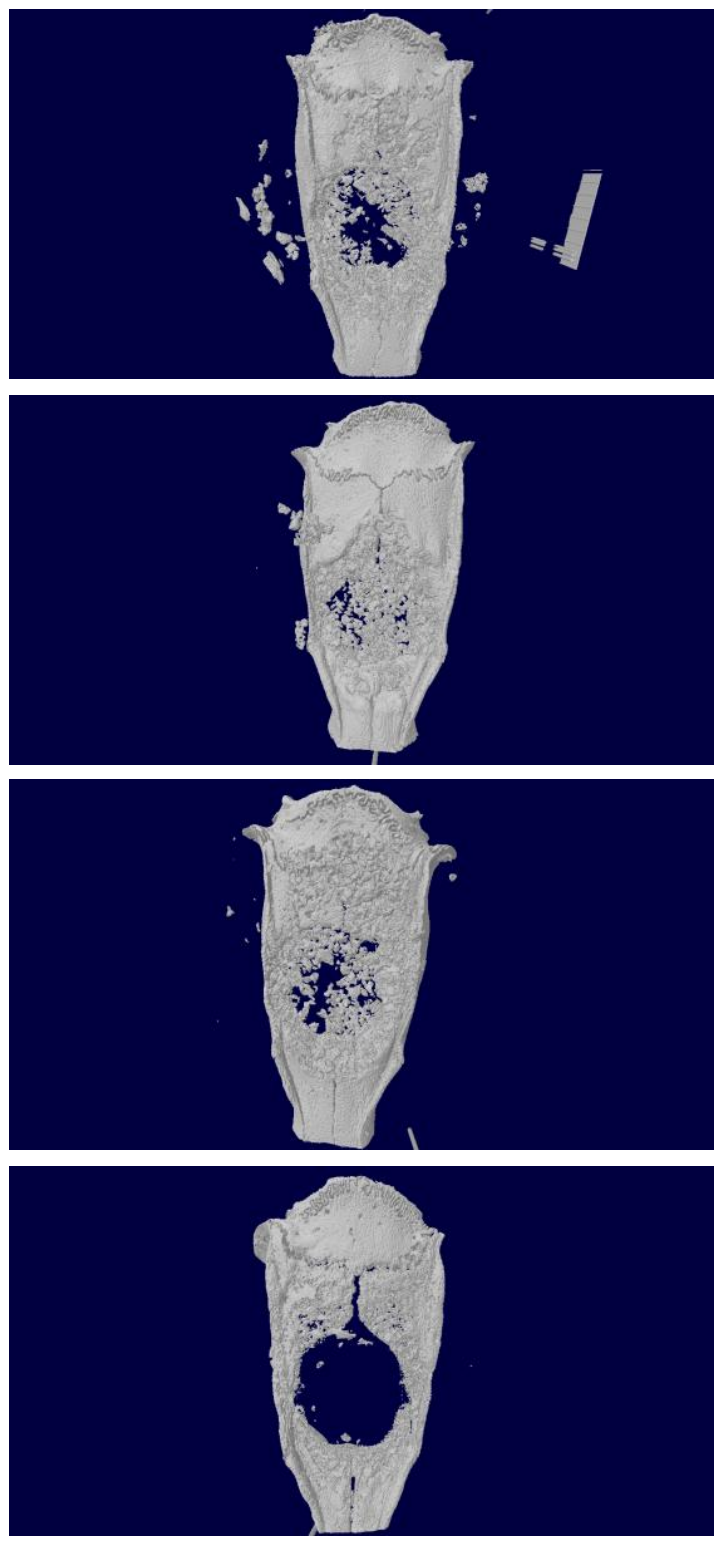
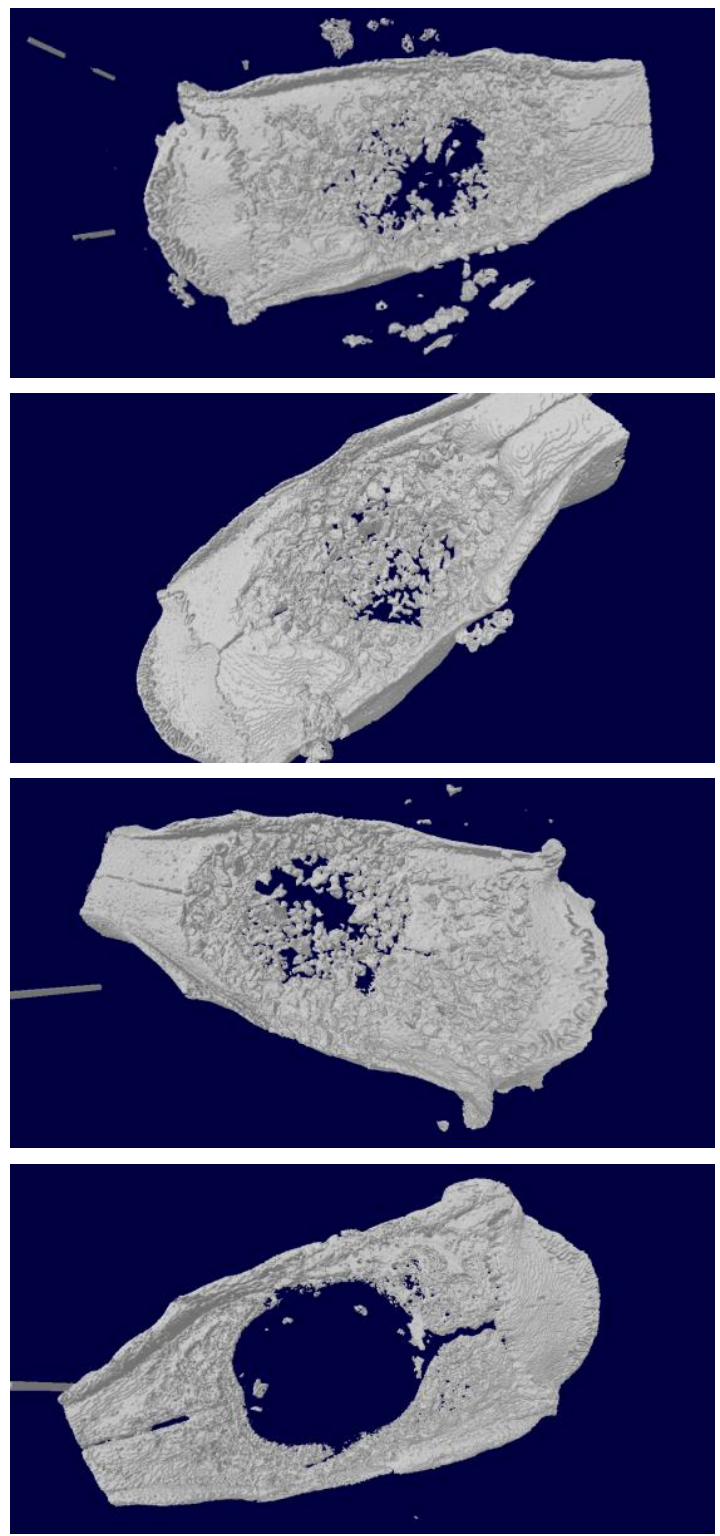

Figura 23 - Imagens do reparo ósseo do grupo enxertado com Bio-Oss após 30 dias de cicatrização ( $n=4$ animais, vista superior e lateral) 
No grupo onde foi empregada a marca comercial Bio-Oss observamos a presença marcante de tecido mineralizado, fechando quase que totalmente o defeito ósseo (Figura 23). Esse material de enxertia composto por osso bovino inorgânico não foi reabsorvido rapidamente possibilitando a manutenção do espaço do tecido ósseo e a não invaginação do tecido conjuntivo, possibilitando, assim, a neoformação óssea.

De acordo com a análise estatística, quando comparamos os três materiais na análise de micro-CT, observamos que o Bio-Oss apresentou maior volume de tecido ósseo significante em relação aos outros materiais, ou seja, as partículas de Bio-Oss se mantiveram no interior do defeito sendo menos reabsorvidas. Dessa maneira esse biomaterial apresenta melhor propriedade de osteocondução, pois, permanecendo no interior do defeito, ele evita a invaginação do tecido conjuntivo e proporciona um arcabouço para o crescimento ósseo (Tabela 2).

Tabela 2 - Comparação entre os três materiais das medidas obtidas pela Micro-CT

\begin{tabular}{|c|c|c|c|c|c|c|c|}
\hline \multirow{2}{*}{ medida } & \multicolumn{2}{|c|}{ Bio-Oss } & \multicolumn{2}{|c|}{$\mathrm{HA}$} & \multicolumn{2}{|c|}{ Tendão } & \multirow{2}{*}{$p$} \\
\hline & média & $d p$ & média & $d p$ & média & $d p$ & \\
\hline $\begin{array}{l}\text { Volume } \\
\text { tecido } \\
\text { ósseo }\end{array}$ & $20,59^{a}$ & 4,56 & $5,35^{b}$ & 2,52 & $1,86^{b}$ & 1,44 & $<0,001$ * \\
\hline $\begin{array}{l}\text { Porcen. } \\
\text { tecido } \\
\text { ósseo }\end{array}$ & $11,49^{a}$ & 2,88 & $3,05^{b}$ & 1,42 & $1,09^{b}$ & 0,89 & $<0,001$ * \\
\hline $\begin{array}{l}\text { Superf. } \\
\text { de } \\
\text { contato }\end{array}$ & $15,98^{a}$ & 2,48 & $9,34^{b}$ & 2,70 & $4,01^{\mathrm{c}}$ & 3,80 & $<0,001$ * \\
\hline $\begin{array}{l}\text { Densid. } \\
\text { superf. } \\
\text { óssea }\end{array}$ & $2,08^{a}$ & 0,46 & $0,80^{b}$ & 0,34 & $0,31^{b}$ & 0,18 & $<0,001$ * \\
\hline
\end{tabular}


Da mesma maneira, quando analisamos a porcentagem de tecido ósseo, que é uma razão do volume de tecido ósseo pelo total de volume analisado, encontramos a mesma significância. Isso evidencia que o grupo do Bio-Oss apresentou maior quantidade de tecido mineralizado, corroborando aos achados anteriores, e, também, que a análise entre os grupos foi fiel, pois foi selecionada a mesma espessura de tecido para ser analisado em todas as amostras, o que é ajustado manualmente.

Outro parâmetro importante que também foi avaliado pela micro-CT foi a superfície de contato ósseo, que representa a área superficial do tecido mineralizado que está interconectado. A interconectividade do tecido ósseo é um quisito importante, pois o contato entre os grânulos proporciona pontes para o aporte de células osteoblásticas, vasos sanguíneos e o crescimento do tecido duro. Quando comparamos os três materiais observamos que o BioOss apresentou maior superfície de contato estatisticamente significante que a hidroxiapatita, que por sua vez foi maior que o tendão bovino (Gráfico 1).

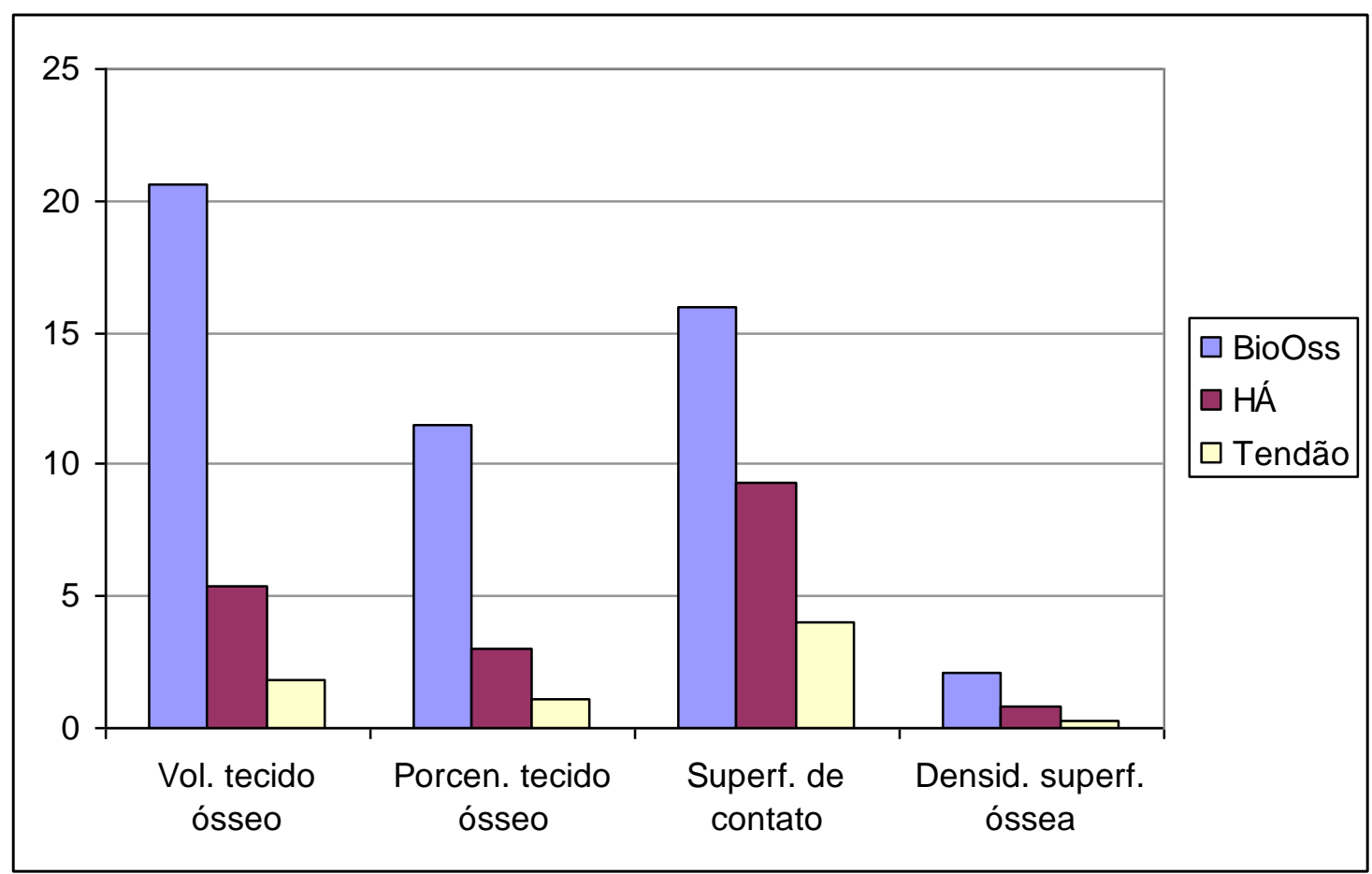

Gráfico 1- Média das medidas de Micro-CT dos três materiais estudados 
A análise de micro-CT forneceu também a densidade de superfície óssea que é a razão da área total da superfície do tecido mineralizado pelo volume total analisado. Esse parâmetro também considera o volume total análisado, o que padroniza todas as amostras. A área superficial do tecido ósseo sempre foi um parâmetro importante na análise morfométrica convencional, porém era obtido através de cortes histológicos seriados em duas dimensões, sendo um procedimento trabalhoso e demorado. O Bio-Oss apresentou maior densidade de superfície óssea estatisticamente significante em relação aos outros materiais, ou seja o grupo BioOss apresentou maior área de superfície mineralizada que os outros grupos (Gráfico $1)$.

Os resultados da análise histológica convencional para os grupos experimentais estão ilustrados nas figuras 24, 25, 26 e 27. A comparação entre os grupos através da análise estatística está ilustrada na Tabela 3 e no Gráfico 2.

Após os 30 dias, o grupo preenchido com Bio-Oss apresentou a presença de grande quantidade de partículas de material no interior do defeito sendo circundadas por um tecido conjuntivo com muitas células e grande quantidade de vasos sanguíneos. Havia grande quantidade de células osteoblásticas ao redor do material. Em relação ao tecido ósseo recém formado, havia a ocorrência principalmente nas margens do defeito e próximo a dura-máter (Figura 24).

No mesmo período a HA sintética apresentou uma grande quantidade de partículas, sendo de menor tamanho quando comparadas as partículas do Bio-Oss. Havia um tecido conjuntivo rico em células e com grande quantidade de vasos sanguíneos. O tecido ósseo neoformado era mais discreto, como também a quantidade de células osteoblásticas (Figura 25).

Já o tendão bovino mineralizado, apresentava-se quase totalmente reabsorvido, dando lugar a um tecido conjuntivo exuberante com pouca quantidade de células. Os vasos sanguíneos não estavam presentes em grande quantidade como apresentavam os outros grupos. Quase que não havia presença de células osteoblásticas e o tecido ósseo recém formado era mínimo (Figura 26). 
$\mathrm{Na}$ figura 27 observamos os cortes histológicos do grupo controle preenchido apenas com coágulo sanguíneo. Ocorreu a perda do espaço do tecido ósseo e presença de um tecido conjuntivo com poucas células e vasos. Presença mínima de tecido recém formado nas margens do defeito, demonstrando o carácter permanente do defeito. 


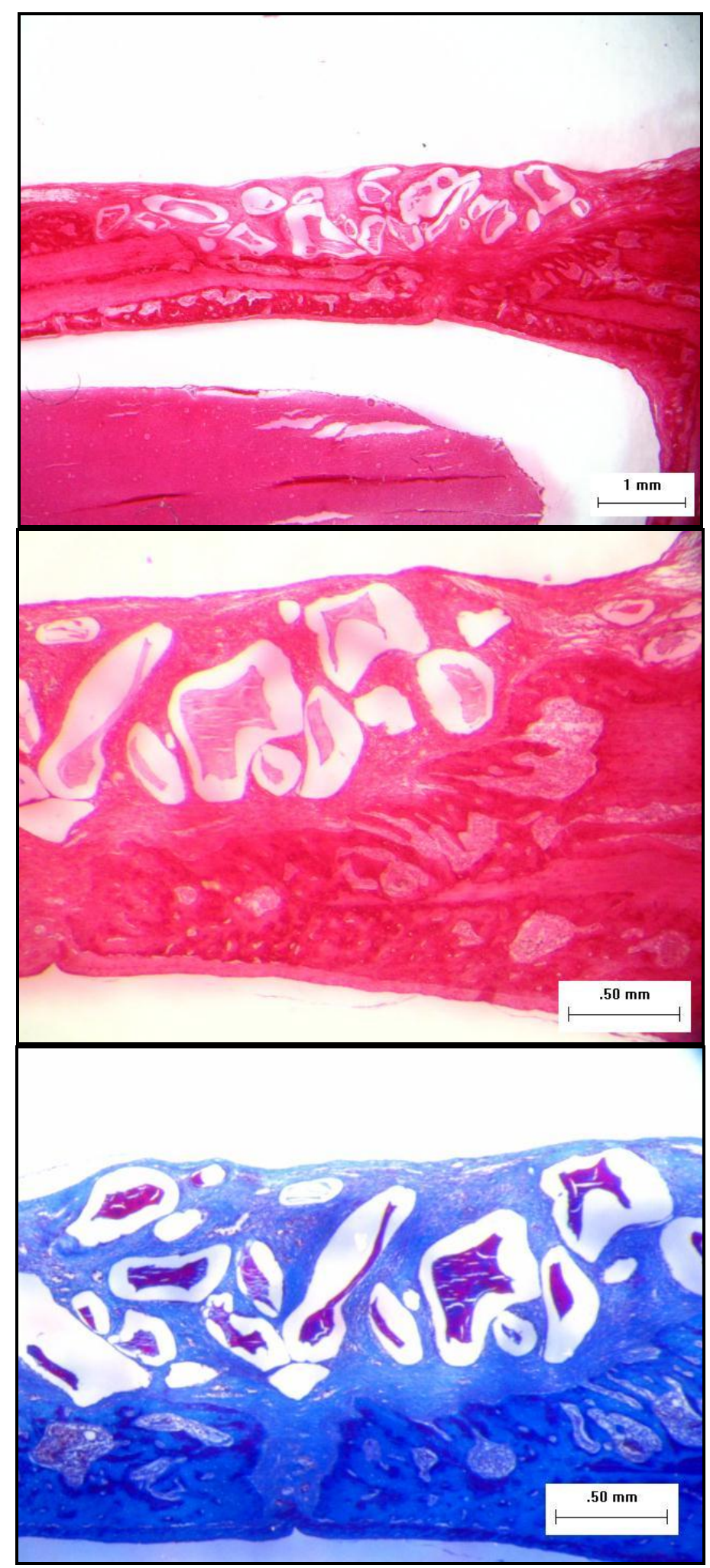

Figura 24 - Fotomicrografias do defeito do grupo Bio-Oss. Notar a grande presença de partículas do material, envoltas por um tecido conjuntivo com muitas células e vasos. Presença de tecido recém formado em forma de rampa nas margens do defeito, principalmente próximo a dura-máter (HE aumento de 20x e 50x e Tricromio de Masson aumento de 50x) 


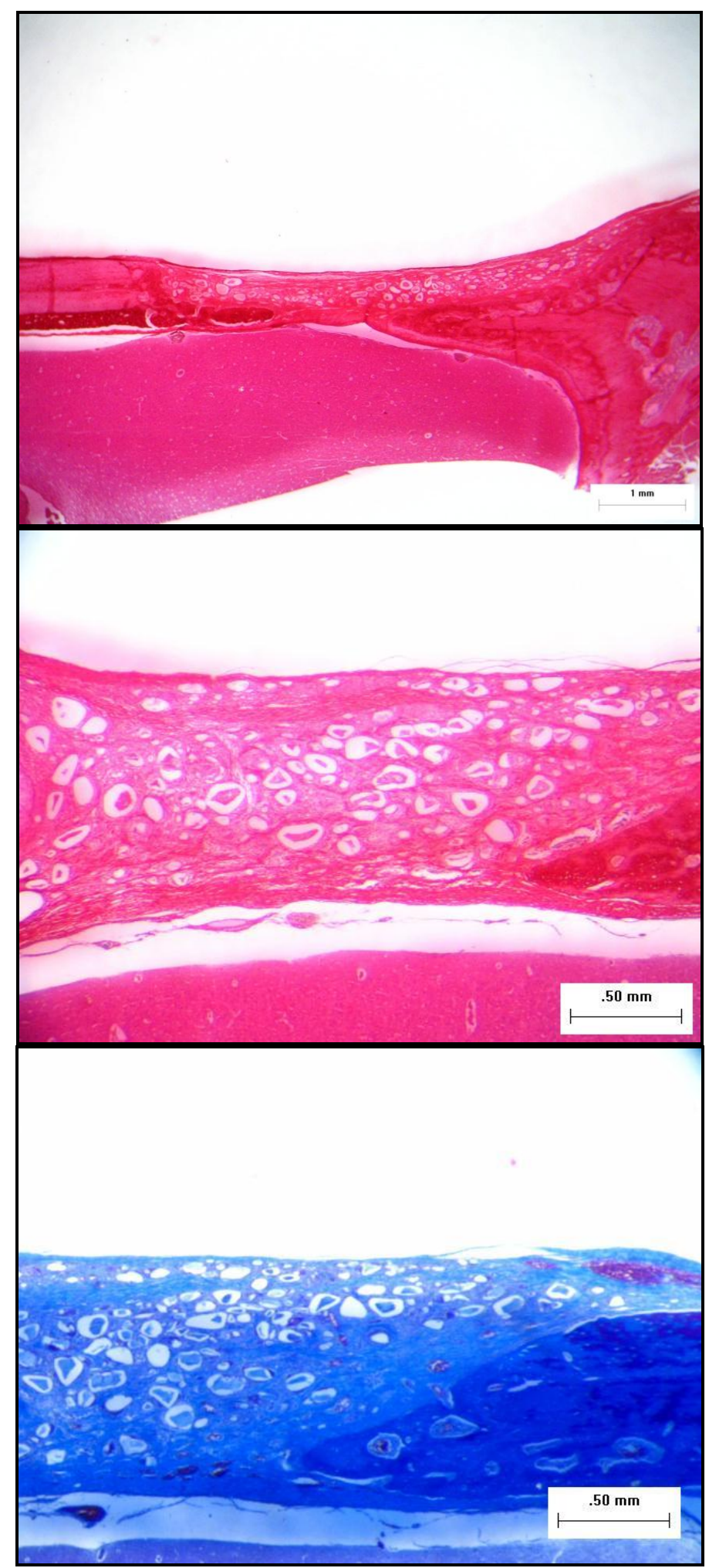

Figura 25 - Fotomicrografias do defeito do grupo da HA sintética. Notar a presença de inúmeras partículas de menor tamanho do material, envoltas por um tecido conjuntivo com células e vasos. Presença de tecido recém formado em forma de rampa nas margens do defeito, principalmente próximo a dura-máter (HE aumento de 20x e 50x e Tricromio de Masson aumento de 50x) 


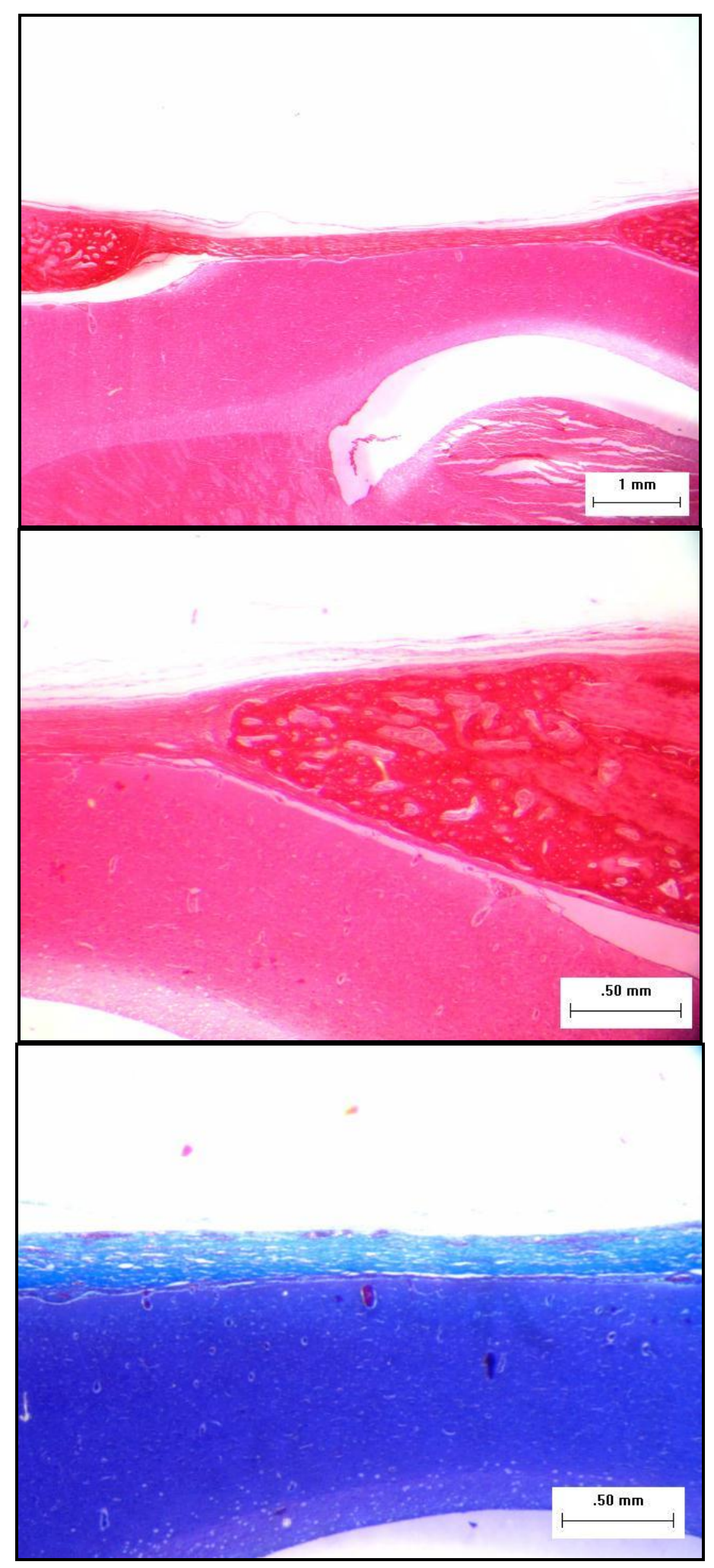

Figura 26 - Fotomicrografias do defeito do grupo do tendão bovino mineralizado. Notar a reabsorção severa do material e a presença de um um tecido conjuntivo com poucas células e vasos. Presença mínima de tecido recém formado nas margens do defeito (HE aumento de 20x e 50x e Tricromio de Masson aumento de 50x) 


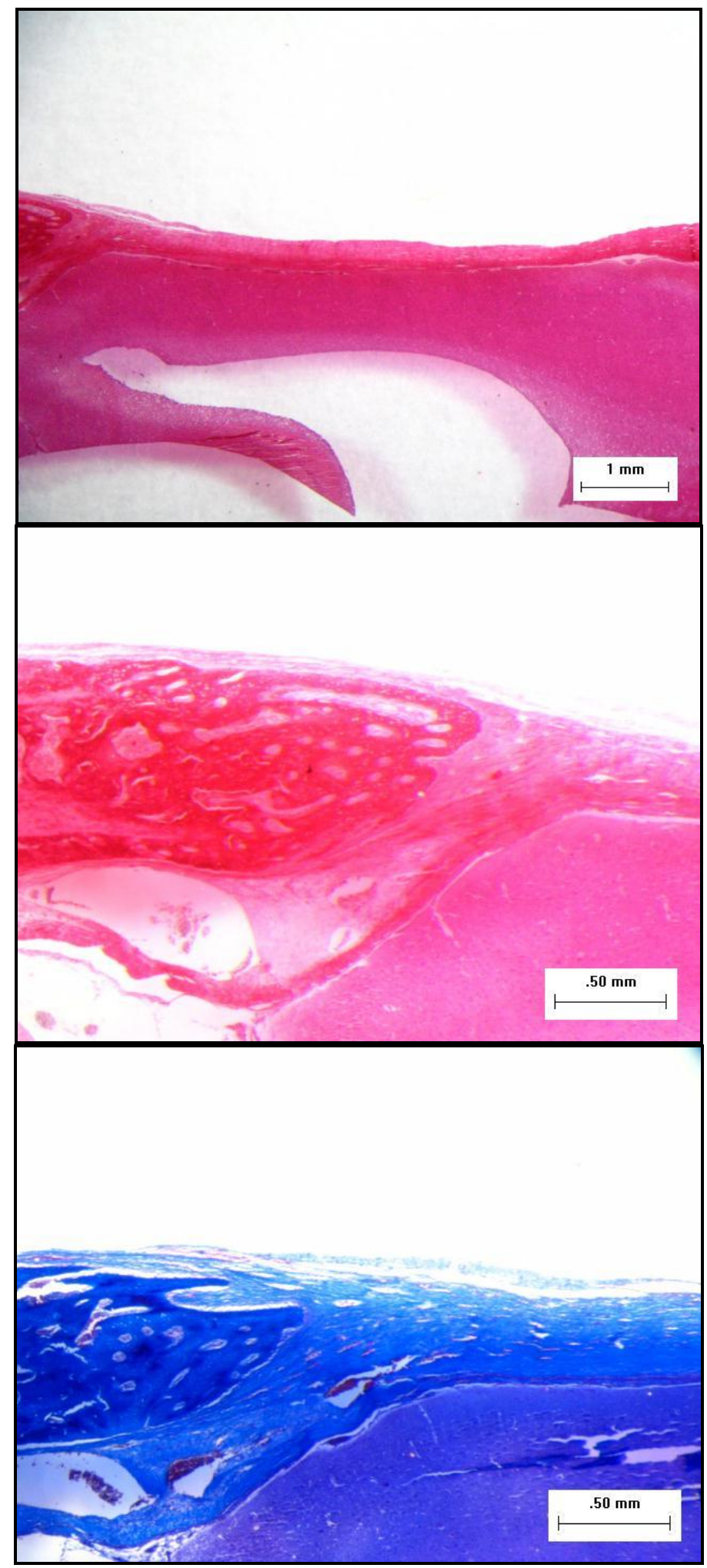

Figura 27 - Fotomicrografias do defeito do grupo controle preenchido apenas com coágulo sanguíneo. Notar a perda do espaço do tecido ósseo e presença de um tecido conjuntivo com poucas células e vasos. Presença mínima de tecido recém formado nas margens do defeito (HE aumento de 20x e 50x e Tricromio de Masson aumento de 50x) 
Quando comparamos os três materiais na análise histológica convencional observamos que o grupo Bio-Oss apresentou maior quantidade de tecido ósseo neoformado que o grupo hidroxiapatita, que por sua vez foi maior que o grupo tendão. Apesar desses resultados numéricos serem bem claros como observamos no Gráfico 2 não foram estatisticamente significantes (Tabela 3). Isso pode ter ocorrido provavelmente pelo fato do tecido ósseo ter um processo lento de mineralização, o qual não foi completamente concluído no período avaliado. No entanto, podemos observar que o Bio-Oss apresentou maior capacidade osteocondutora que a hidroxiapatita, a qual foi maior que o tendão. Essa osteocondução é uma condição imprecindível para a formação óssea futura.

Tabela 3 - Comparação entre os três materiais das medidas obtidas pela avaliação histológica convencional

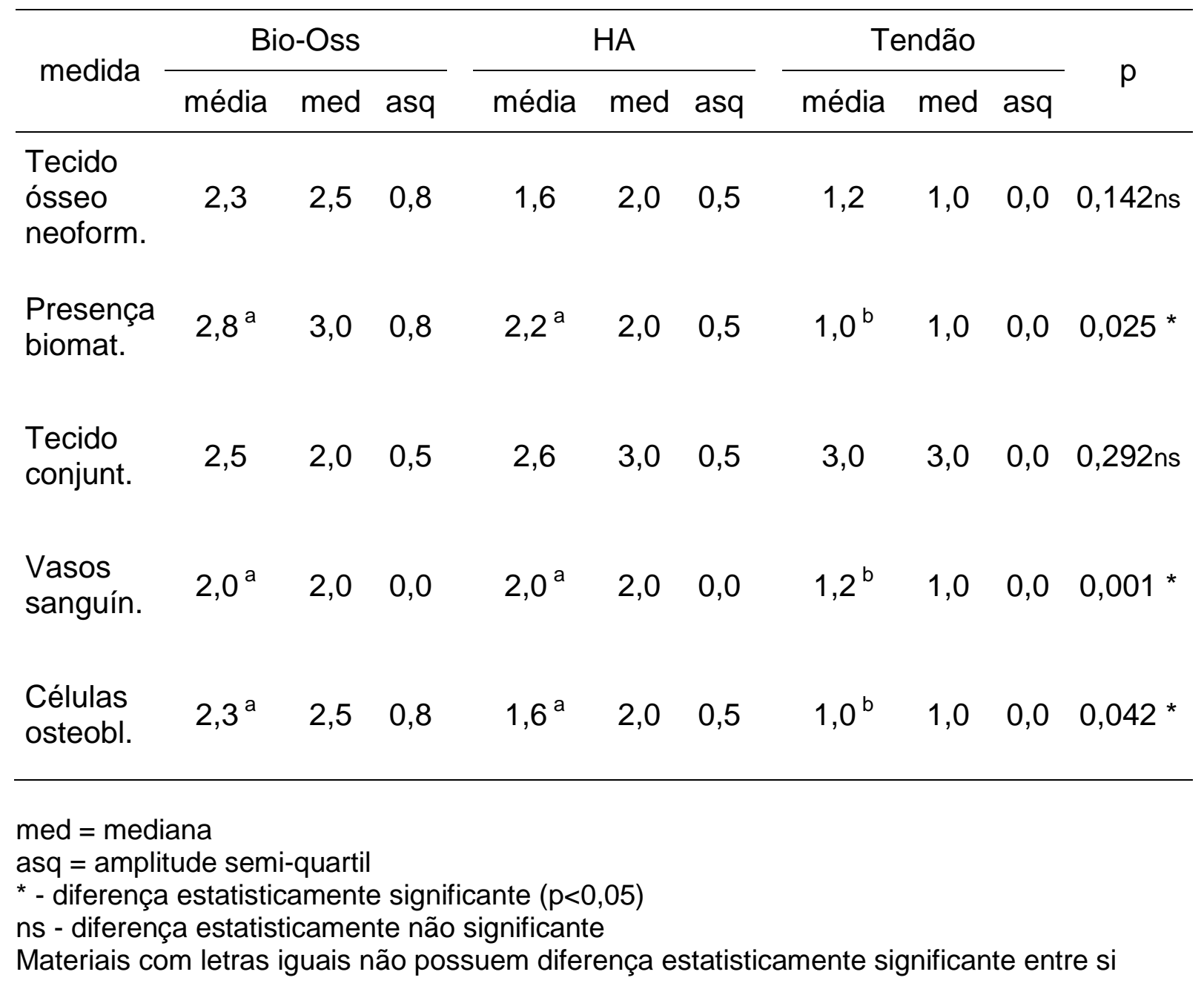


Em relação a presença dos biomateriais no interior do defeito, o Bio-Oss e a hidroxiapatita obtiveram resultados estatisticamente semelhantes, e ambos apresentaram diferença significante em relação ao tendão mineralizado (Tabela 3). Tanto o Bio-Oss como a HA permaneceram no interior do defeito no período avaliado de forma semelhante, porém os grânulos de Bio-Oss eram maiores e estavam em um número um pouco maior que os da HA (Figuras 24 e 25; Gráfico 2). Já o tendão mineralizado fora quase totalmente reabsorvido no período avaliado, apresentando diferença estatisticamente significante dos outros grupos. $O$ tendão mineralizado sofreu intensa reabsorção aos 30 dias, não sendo capaz de manter o espaço para o crescimento ósseo. Isso denota sua fraca capacidade de osteocondução.

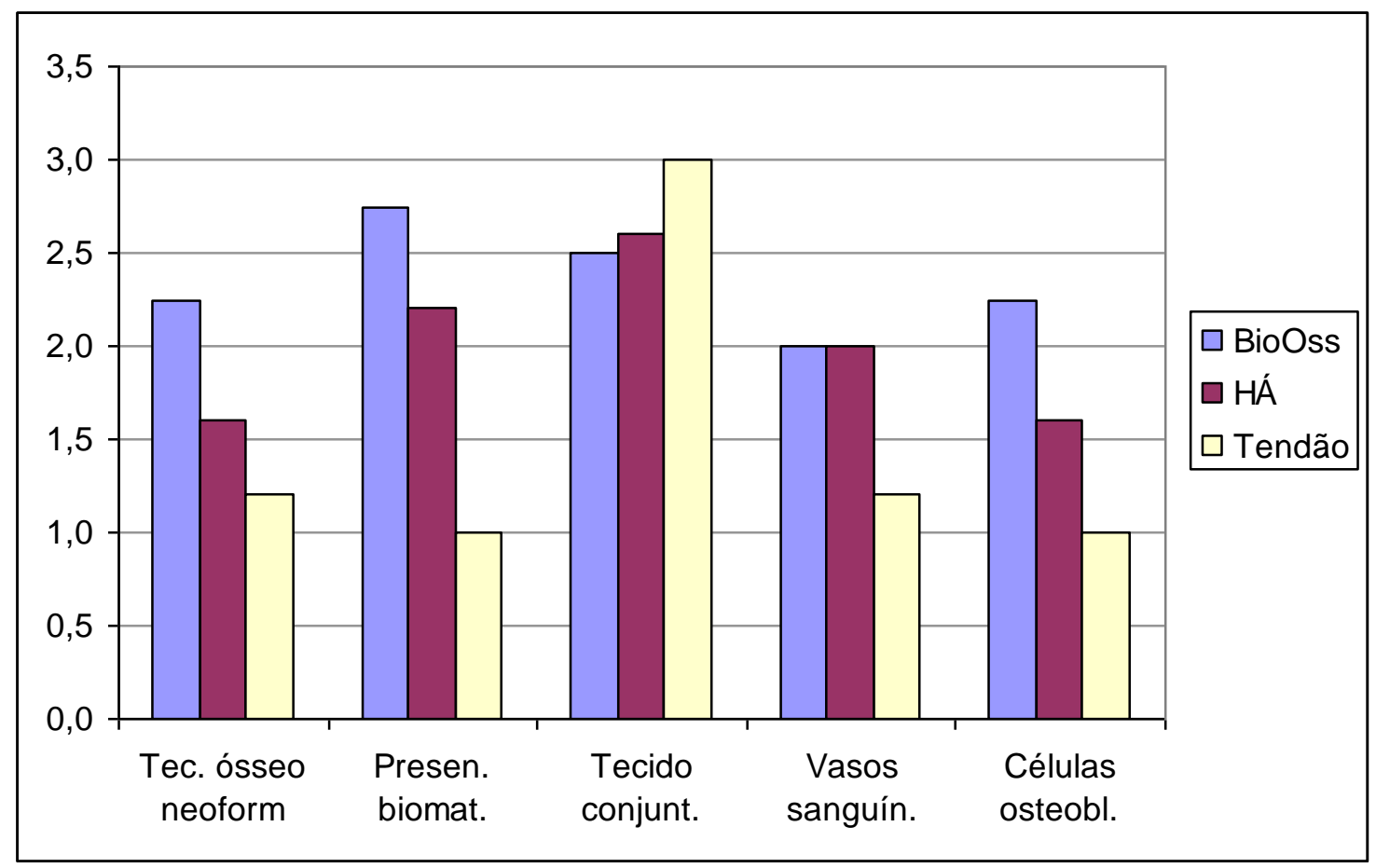

Gráfico 2 - Média das medidas da avaliação histológica convencional para os três materiais estudados

Apesar do grupo do tendão mineralizado apresentar maior quantidade de tecido conjuntivo que os demais, como observamos no Gráfico 2, não há diferença estatisticamente significante entre os grupos nesse parâmetro, como constatamos 
na Tabela 3. Apesar de não ter ocorrido diferença estatística significante, o tecido conjuntivo presente no grupo do tendão apresentava-se com menos células e vasos, enquanto nos demais grupos o tecido conjuntivo era rico em células envolvidas no reparo tecidual e vasos sanguíneos, denotando o caráter regenerativo da lesão.

Os vasos sanguíneos que são de suma importância para a formação óssea também foram mensurados na análise histológica. Os grupos Bio-Oss e HA não apresentaram diferença estatística significante entre si, porém o grupo do tendão foi significantemente menor. Isso mostra que o Bio-Oss e a HA têm uma grande vantagem no processo de osteogênese que é a presença de vasos sanguíneos (Tabela 3). No entanto o tendão mineralizado apresenta um tecido conjuntivo com número reduzido de vasos sanguíneos.

Em relação as células osteoblásticas, os grupos BioOss e HA obtiveram melhores resultados e não apresentaram diferença estatística significante entre si. Já o grupo do tendão mineralizado apresentou menor quantidade de células osteoblásticas, sendo significantemente menor que os demais (Tabela 3).

A Tabela 4 mostra a correlação entre os parâmetros avaliados na micro-CT e na histologia convencional. Em relação a presença do tecido conjuntivo obtido através da análise histológica convencional, quando comparamos-o a todos os outros parâmetros da micro-CT, observamos que há uma correlação negativa, ou seja, com o aumento de uma variável há a diminuição da outra. Isso era esperado, pois todos os parâmetros da micro-CT são indicativos diretos da presença de osso, ou seja, com o aumento da quantidade de tecido ósseo na amostra, há o aumento dos valores desses parâmetros e consequentemente há diminuição do tecido conjuntivo. Observar os valores negativos do parâmetro tecido conjuntivo ilustrados na Tabela 4.

Quando comparamos o volume do tecido ósseo obtido através da micro-CT aos outros parâmetros da histologia convencional observamos que há uma correlação estatística significante. A correlação mais forte ocorre entre os valores de volume do tecido ósseo e a presença de células osteoblásticas, seguido pela presença do biomaterial, vasos sanguíneos e tecido ósseo neoformado, porém todas as correlações são estatisticamente significante. 
Tabela 4 - Correlação entre as medidas da Micro-CT e da histologia convencional.

\begin{tabular}{|c|c|c|}
\hline Correlação & \multirow{2}{*}{$\frac{r}{0,56}$} & \multirow{2}{*}{$\frac{P}{0,036^{*}}$} \\
\hline x Tec. Ósseo Neof. & & \\
\hline x Prese. Biomat. & 0,68 & $0,007^{*}$ \\
\hline x Tecido Cojun. & $-0,59$ & $0,027^{*}$ \\
\hline x Vasos Sanguín. & 0,59 & $0,027^{\star}$ \\
\hline x Cel. Osteobl. & 0,71 & $0,004^{*}$ \\
\hline Porc. Tec. Ósseo x Tec. Ósseo Neof. & 0,56 & $0,036^{*}$ \\
\hline Porc. Tec. Ósseo x Prese. Biomat. & 0,68 & $0,007^{\star}$ \\
\hline Porc. Tec. Ósseo x Tecido Cojun. & $-0,59$ & $0,027^{\star}$ \\
\hline Porc. Tec. Ósseo x Vasos Sanguín. & 0,59 & $0,027^{*}$ \\
\hline Porc. Tec. Ósseo x Cel. Osteobl. & 0,71 & $0,004^{*}$ \\
\hline Superf. Contato x Tec. Ósseo Neof. & 0,66 & $0,010^{*}$ \\
\hline Superf. Contato x Prese. Biomat. & 0,72 & $0,004^{*}$ \\
\hline Superf. Contato x Tecido Cojun. & $-0,64$ & $0,013^{*}$ \\
\hline Superf. Contato x Vasos Sanguín. & 0,59 & $0,027^{*}$ \\
\hline Superf. Contato x Cel. Osteobl. & 0,79 & $0,001^{*}$ \\
\hline Dens. Sup. Óssea x Tec. Ósseo Neof. & 0,51 & $0,065 \mathrm{~ns}$ \\
\hline Dens. Sup. Óssea x Prese. Biomat. & 0,65 & $0,012^{*}$ \\
\hline Dens. Sup. Óssea x Tecido Cojun. & $-0,59$ & $0,027^{*}$ \\
\hline Dens. Sup. Óssea x Vasos Sanguín. & 0,51 & $0,063 \mathrm{~ns}$ \\
\hline Dens. Sup. Óssea x Cel. Osteobl. & 0,68 & $0,007^{*}$ \\
\hline
\end{tabular}

* - correlação estatisticamente significante $(p<0,05)$

ns - correlação estatisticamente não significante

O sinal negativo na correlação indica que o aumento de uma variável implica em diminuição da outra 
Como a porcentagem do tecido ósseo é um parâmetro derivado do volume do tecido ósseo e a metodologia da micro-CT foi padronizada para todas as amostras, quando correlacionamos a porcentagem do tecido ósseo aos outros parâmetros da análise histológica convencional encontramos uma correlação semelhante a do volume do tecido ósseo, descrita no parágrafo anterior. Portanto, com o aumento da porcentagem do tecido ósseo há o aumento de todos os outros parâmetros da histologia convencional, exceto o tecido conjuntivo descrito anteriormente (Tabela 4).

A superfície de contato ósseo corresponde a interconectividade do tecido ósseo obtida através da micro-CT. Quando comparamos-a aos outros parâmetros da análise histológica convencional, constatamos que há uma forte correlação com a presença de células osteoblásticas, seguido pela presença do biomaterial, tecido ósseo neoformado e finalmente a presença de vasos sanguíneos, entretanto todos os métodos têm correlação estatisticamente significante (Tabela 4).

A densidade de superfície óssea que é um parâmetro derivado da área de superfície óssea obtida através da micro-CT não tem correlação estatisticamente significante com a presença de vasos sanguíneos e o tecido ósseo neoformado. Há uma correlação apenas com as células osteoblásticas e a presença do biomaterial (Tabela 4). 


\section{DISCUSSÃO}

A caracterização físico-química teve por objetivo avaliar os constituintes do tendão bovino mineralizado e as características morfológicas dos materiais. A termogravimetria permite avaliar a perda de massa de uma amostra em função do aquecimento. A análise demonstrou que a matriz mineralizada possui uma quantidade de resíduo de 60,9\% a uma temperatura de $750^{\circ} \mathrm{C}$ (Figura 13). Esse resíduo provém do material inorgânico depositado sobre o tendão. Essa perda de aproximadamente $40 \%$ de massa corresponde ao constituinte orgânico proveniente do colágeno bovino. O Bio-Oss apresenta uma pequena quantidade de constituintes orgânicos na sua composição, sendo constituído basicamente por hidroxiapatita bovina (JENSEN, 2012).

A calorimetria exploratória diferencial (DSC) foi realizada apenas para o tendão bovino mineralizado, já que não ocorrerão variações de energia significativa para materiais inorgânicos nessa temperatura empregada. As temperaturas de desnaturação (Td) faram de: $46,7^{\circ} \mathrm{C}$ para o tendão bovino, $59,0^{\circ} \mathrm{C}$ para o tendão bovino mineralizado e $56,1^{\circ} \mathrm{C}$ para o tendão bovino mineralizado e esterilizado (Figura 14). Essas temperaturas ao redor dos $40^{\circ} \mathrm{C}$ correspondem à desnaturação do colágeno, conforme foi relatado anteriormente por Ogawa (2001).

A análise por microscopia eletrônica de varredura é uma técnica bastante utilizada na caracterização dos substitutos ósseos. Através dela pode-se observar a topografia superficial dos biomateriais, especialmente em relação ao aspecto microscópico, tamanho dos grânulos e porosidade, como podemos observar nas figuras $15-18$.

A HA sintética apresenta uma microestrutura porosa com uma rede de poros interconectados. O tamanho de poros de 200 a $500 \mu \mathrm{m}$ proporciona um arcabouço para a entrada de células osteogênicas e capilares sanguíneos, semelhante ao osso bovino inorgânico sinterizado a baixa temperatura, como o Bio-Oss, que também foi utilizado nesse estudo. Na proliferação dos osteoblástos no interior do material, uma única célula requer o contato com pelo menos mais três células através de uma rede 
interconectada de poros, os quais devem ter pelo menos $100 \mu \mathrm{m}$ de diâmetro, o que é aproximadamente três vezes o tamanho do osteoblasto, que tem $30 \mu \mathrm{m}$ de diâmetro. Uma estrutura porosa variando de 200 a $400 \mu \mathrm{m}$ proporciona o crescimento e diferenciação celular no seu interior e facilita a nutrição através dos capilares sanguíneos (WANG, 2004).

Os resultados microestruturais da superfície do tendão bovino mineralizado obtidos a partir da microscopia eletrônica de varredura estão ilustrados nas figuras 15 e 16, respectivamente. Pode-se observar a presença de inúmeros grânulos minerais depositados sobre a matriz orgânica. O material apresenta superfície irregular com poros e fendas que favorecerão o repovoamento celular. As imagens de MEV do Bio-Oss mostram um material altamente poroso, que permitirá o crescimento celular e vascular no seu interior. As trabéculas fornecerão o arcabouço para a condução e manutenção do espaço para o crescimento ósseo (Figuras 17 e 18). A microscopia eletrônica de varredura é um método eficaz na análise da topografia superficial dos materiais, porém não fornece dados importantes sobre 0 interior dos mesmos. A estimativa da microestrutura utilizando microscopia eletrônica de varredura, muitas vezes, produz resultados pouco precisos com base apenas na estimativa da superfície e, portanto, a análise de imagens por micro-CT da porosidade total e distribuição de carga volumétrica são mais eficazes (NIEMELÄ, 2011).

O modelo experimental normalmente empregado para avaliação biológica de biomateriais de substituição óssea é o tratamento de defeito de tamanho crítico em calvária de animais. Por mais de duas décadas essa metodologia vem sendo amplamente utilizada na literatura (BOHNING, 1999; BOSCH, 1995; BOSCH, 1998; LINDE, 1993). Nessa técnica o tecido ósseo não tem a capacidade de regenerar espontaneamente, requerendo a utilização de um enxerto ou um substituto ósseo com potencial de arcabouço para a promoção da neoformação óssea.

A metodologia utilizada nesse estudo mostrou-se eficaz quando se objetivou avaliar a capacidade de osteocondutibilidade dos substitutos ósseos. O modelo animal empregado que avaliou alguns parâmetros de regeneração óssea deve satisfazer alguns critérios, como, por exemplo: o tamanho do defeito não pode ser menor que o tamanho crítico de cada espécie já relatado na literatura, a metodologia 
não deve ser muito onerosa; a técnica cirúrgica não deve ser muito complicada; o sítio de implantação deve conter osso cortical e esponjoso; baixa morbidade; estabilidade do enxerto e impossibilidade de fratura; finalmente, o método deve ser capaz de quantificar o tecido regenerado e o remanescente do implante, tanto do ponto de vista radiográfico quanto histológico (KOCHI, 2009).

A calvária de animais é uma região anatômica amplamente utilizada em modelos experimentais de defeito crítico devido a sua similaridade morfológica e embrionária com a região craniofacial (SCHLEGEL, 2006). Costa et al. (2010) relataram que a calvária é uma área com limitados esforços mecânicos e relativa estabilidade das estruturas adjacentes, proporcionando um ambiente ideal para os estudos da interação entre biomateriais, o osso recém formado e o osso maduro.

Foi utilizado a calvária de ratos nesse estudo porque contém uma quantidade pequena de osso trabecular, facilitando dessa forma a acomodação do enxerto. Confeccionamos um defeito de $8 \mathrm{~mm}$ de diâmetro que corresponde ao defeito de tamanho crítico que não cicatrizará totalmente durante toda a vida do animal (PRIPATNANONT, 2007). A cicatrização do defeito de calvária inicia-se normalmente pelas margens da ferida cirúrgica, a partir da dura-máter subjacente ou do periósteo suprajacente. Nesse estudo, verificou-se um maior crescimento a partir das margens sobre a dura-máter, com aspecto de rampa, para todos os grupos. Quanto maior era a capacidade osteocondutora do material, maior era esse crescimento.

Na figura 27 observamos os cortes histológicos do grupo controle preenchido apenas com coágulo sanguíneo. Ocorreu a perda do espaço do tecido ósseo e presença de um tecido conjuntivo com poucas células e vasos. Presença mínima de tecido recém formado nas margens do defeito, demonstrando o caráter permanente do defeito. Os resultados evidenciaram que no grupo controle utilizando-se o coágulo sanguíneo, não ocorreu a consolidação óssea no centro, tampouco na periferia do defeito. Isso está de acordo com os resultados de pesquisas anteriores, as quais mostraram que o coágulo sozinho exibe uma formação óssea mínima na periferia mesmo em períodos longos (LEE, 2010; LU 2004). 
O grupo controle apresentou uma pequena e limitada formação óssea na periferia do defeito (Figura 27), o que corrobora aos achados de alguns autores (HE, 2008; HUH, 2005). Schmitz et al. (2009) descreveram o comportamento celular no defeito crítico, observando que a liberação de fatores de crescimento, como as proteínas ósseas morfogenéticas, a partir da margem do defeito levam a diferenciação das células mesenquimais em osteoblastos. Essas células formam e mineralizam a matriz óssea criando ilhas de mineralização que servirão de andaime para o crescimento de novo tecido ósseo. Entretanto, devido a falta de fatores de crescimento e nutrição no grupo controle, não ocorre muita diferenciação osteoblástica e formação óssea além das margens da ferida. Consequentemente, os osteoblastos não são capazes de formar e mineralizar a matriz óssea, dando lugar então ao tecido conjuntivo fibroso (RUEHE, 2009).

Os materiais avaliados nesse estudo apresentaram bons resultados de biocompatibilidade, biodegradabilidade e podem estar disponíveis em grande quantidade e de várias formas, dessa maneira, têm grande potencial de serem utilizados na reconstrução óssea. Esse estudo tem um caráter inovador, pois comparou a hidroxiapatita e o tendão bovino mineralizado experimentais a uma marca comercial internacionalmente conhecida, empregando modelo animal de defeito ósseo de tamanho crítico avaliado através da histologia convencional e da micro-CT.

Quando comparamos os três materiais na análise histológica convencional observamos que o grupo Bio-Oss apresentou maior quantidade de tecido ósseo neoformado que a hidroxiapatita, que por sua vez foi maior que o tendão. Apesar desses resultados numéricos serem bem claros como observamos no Gráfico 2 não foram estatisticamente significantes (Tabela 3). Isso pode ter ocorrido provavelmente pelo fato do tecido ósseo ter um processo lento de mineralização, o qual não foi completamente concluído no período avaliado. No entanto, podemos observar que o BioOss apresentou maior capacidade osteocondutora que a hidroxiapatita, a qual foi maior que o tendão. Essa osteocondução é uma condição imprescindível para a formação óssea futura.

Após os 30 dias, o grupo preenchido com Bio-Oss apresentou a presença de grande quantidade de partículas de material no interior do defeito sendo circundadas 
por um tecido conjuntivo com muitas células e grande quantidade de vasos sanguíneos. Havia grande quantidade de células osteoblásticas ao redor do material. Em relação ao tecido ósseo recém formado, havia a ocorrência principalmente nas margens do defeito e próximo a dura-máter (Figura 24). Em outros estudos uma pequena degradação das partículas de BioOss foi observada quinze meses após a enxertia de seio maxilar em humanos (BUSENLECHNER, 2009; SCHLEGEL, 2003). Uma degradação mais pronunciada do material restando apenas algumas partículas após seis meses foi relatada em apenas um estudo (TERHEYDEN, 1999). Nenhum estudo quantificou a degradação do BioOss com o tempo. Não foi encontrada diferença estatisticamente significante na proporção das partículas remanescentes de Bio-Oss entre 7 e 18 meses (MCALLISTER, 1999). Esses achados justificam a grande quantidade de partículas de BioOss encontrada no interior do defeito, denotando sua lenta degradação.

Em relação a presença dos biomateriais no interior do defeito, o Bio-Oss e a hidroxiapatita obtiveram resultados estatisticamente semelhantes, e ambos apresentaram diferença significante em relação ao tendão mineralizado (Tabela 3). Tanto o BioOss como a HA permaneceram no interior do defeito no período avaliado de forma semelhante, porém os grânulos de Bio-Oss eram maiores e estavam em um número um pouco maior que os da HA (Figuras 24 e 25; Gráfico 2). Já o tendão mineralizado fora quase totalmente reabsorvido no período avaliado, apresentando diferença estatisticamente significante dos outros grupos. O tendão mineralizado sofreu intensa reabsorção aos 30 dias, não sendo capaz de manter o espaço para o crescimento ósseo. Isso denota sua fraca capacidade de osteocondução.

No mesmo período a HA sintética apresentou uma grande quantidade de partículas, sendo de menor tamanho quando comparadas as partículas do Bio-Oss. Havia um tecido conjuntivo rico em células e com grande quantidade de vasos sanguíneos. O tecido ósseo neoformado era mais discreto, como também a quantidade de células osteoblásticas (Figura 25). O tamanho das partículas da hidroxiapatita utilizadas nesse estudo eram menores que 0,2 $\mathrm{mm}$ de diâmetro, as quais eram menores ao proposto por Pallesen et al. (2002), que demonstraram que partículas de 0,5 a $2 \mathrm{~mm}^{3}$ são mais indicadas para regeneração óssea que partículas de $10 \mathrm{~mm}^{3}$. O tamanho das partículas de HA parece influenciar também no potencial osteogênico das células tronco mesenquimais, como observado num 
estudo in vitro de Weissenboeck el al. (2006). Os autores constataram que partículas pequenas apresentavam altos índices de atividade de fosfatase alcalina específica.

Já o tendão bovino mineralizado, apresentava-se quase totalmente reabsorvido, dando lugar a um tecido conjuntivo exuberante com pouca quantidade de células. Os vasos sanguíneos não estavam presentes em grande quantidade como apresentavam os outros grupos. Quase que não havia presença de células osteoblásticas e o tecido ósseo recém formado era mínimo (Figura 26). O'hara et al. (2012) investigaram a incorporação de fosfato de cálcio em fibras colágenas provenientes do tendão bovino in vitro. Esse estudo sugeriu uma potencial aplicação desse compósito no tratamento de fratura de vértebras, no entanto estudos in vivo seriam necessários para a comprovação clínica da sua efetividade, especialmente em relação a degradação. Os resultados dessa investigação in vivo mostraram que esse compósito é rapidamente reabsorvido e melhorias na sua composição devem ser feitas para melhorar sua performance clínica.

Apesar do grupo do tendão mineralizado apresentar maior quantidade de tecido conjuntivo que os demais, como observado no Gráfico 2, não há diferença estatisticamente significante entre os grupos nesse parâmetro, como constatado na Tabela 3. A diferenciação celular é influenciada pelas propriedades estruturais, hidrofílicas e composição química da superfície dos biomateriais. Esses fatores também influenciam na resposta fisiológica, migração e proliferação celular. A interação entre a superfície do material e as células determina como será a regeneração do tecido. As modificações in sito que ocorrem na superfície do material, como, por exemplo, a reabsorção severa, aumentam a migração, diferenciação, adesão e proliferação dos fibroblastos (WU, 2006). Devido a maior reabsorção do tendão bovino mineralizado no período avaliado, foi encontrada maior quantidade de tecido conjuntivo nesse grupo. Esse tecido tinha uma característica de poucos vasos sanguíneos e células reparadoras denotando seu caráter de estabilização. Nos outros grupos esse tecido mole não mineralizado provavelmente estava relacionado ao processo de reparo ósseo.

Um fator relevante na formação óssea é a relação entre angiogênese e osteogênese. Vários estudos demonstraram que a osteogênese é dependente da angiogênese, e que a tensão de oxigênio tecidual determina a diferenciação das 
células mesenquimais em osteoblástos ou condroblastos (GERBER, 2000; HAUSMAN, 2001; PELISSIER, 2003). Os vasos sanguíneos que são de suma importância para a formação óssea também foram mensurados na análise histológica. Os grupos Bio-Oss e HA não apresentaram diferença estatística significante entre si, porém o grupo do tendão foi significantemente menor. Isso mostra que o Bio-Oss e a HA têm uma grande vantagem no processo de osteogênese que é a presença de vasos sanguíneos (Tabela 3). A hidroxiapatita e o Bio-Oss, devido a sua semelhança com os minerais do osso natural, apresentam excelente biocompatibilidade, capacidade osteogênica e bioatividade (PILLIAR, 2001; CHU, 2002). No entanto o tendão mineralizado apresenta um tecido conjuntivo com tendência a estabilização pelo número reduzido de vasos sanguíneos.

Em relação as células osteoblásticas, os grupos Bio-Oss e HA obtiveram melhores resultados e não apresentaram diferença estatística significante entre si. Já o grupo do tendão mineralizado apresentou menor quantidade de células osteoblásticas, sendo significantemente menor que os demais (Tabela 3). O osso bovino inorgânico, a hidroxiapatita e os derivados de fosfato de cálcio apresentam por excelência propriedades osteoindutivas, as quais parecem estimular a diferenciação e proliferação dos osteoblastos, especialmente no defeito crítico empregado nesse estudo, pois a calvária apresenta uma pequena quantidade de medula óssea (CHEN, 2004). Urist et al. (1984) implantaram proteínas ósseas morfogenéticas associadas ao fosfato de cálcio no músculo de ratos. Foi relatado nesse estudo doze vezes mais formação óssea na presença do fosfato de cálcio que na proteína óssea morfogenética sozinha. O Bio-Oss e a hidroxiapatita apresentaram melhores resultados na quantidade de osteoblastos, devido ao caráter osteoindutor e na persistência do material no interior do defeito. Apesar do tendão mineralizado apresentar fosfato de cálcio na sua composição, isso parece não ter influenciado significativamente no recrutamento dos osteoblastos, provavelmente devido a pequena quantidade mineral no material.

Atualmente a análise de micro-CT tem sido utilizada para quantificar a morfologia óssea e a microestrutura de biomateriais (GULDBERG, 2008). Consequentemente, muitos investigações empregaram a micro-CT para avaliar a formação da matriz mineralizada sobre diferentes tipos de biomateriais in vitro e in vivo (JONES, 2004; OLIVEIRA, 2007; PORTER, 2007). O crescimento ósseo no 
interior dos biomateriais são limitados a vários fatores, como, por exemplo, a incompleta interconectividade dos poros, degradação precoce do arcabouço e falta de nutrição por baixa vascularização (OTSUKI, 2006). Esses estudos podem ser realizados in vitro ou in vivo, através de cultura de células, da implantação em sítios ectópicos e em defeitos ósseos de tamanho crítico. A análise de micro-CT pode ter duas abordagens principais, primeiramente, quantificar a arquitetura de arcabouços poliméricos fornecendo parâmetros como porosidade, interconectividade e anisotropia, adicionalmente, avaliar os outros parâmetros envolvidos no processo de mineralização do reparo ósseo (JONES, 2007; LIN, 2003; OEST, 2007).

Efeoglu et al. (2007) avaliaram o reparo ósseo através de micro-CT em defeitos críticos em calvária de coelhos utilizando uma mistura de beta-fosfato tricálcio e plasma rico em plaquetas por um período de 4 e 12 semanas. Quando comparou-se o volume de tecido ósseo recém formado nesses períodos, não foram encontradas diferenças estatisticamente significante entre os grupos. Segundo o autor, isso pode ter ocorrido devido a remodelação do tecido ósseo imaturo, o qual desenvolve a matriz óssea até o seu limite nas primeiras 4 semanas e, posteriormente, apenas mineraliza nas outras 12 semanas. Por isso as primeiras quatro semanas são fundamentais para a definição do que pode ocorrer futuramente. Se o material foi capaz de manter o espaço da matriz óssea nas primeiras 4 semanas, certamente formará osso posteriormente. Caso contrário, se o tecido conjuntivo já ocupou o espaço do tecido ósseo, certamente, por uma questão de concorrência, não formará osso naquele local. Andrade et al. (2010) observaram um pico de osteogênese do osso autógeno aos 3, 7 e 14 dias após a cirurgia, mostrando que esses eventos são imprescindíveis para a formação óssea futura.

Alguns estudos semelhantes avaliaram a regeneração óssea em defeitos críticos através da micro-CT. Cacciafesta et al. (2001), Lutolf et al. (2003) e Verna et al. (2002) relataram o defeito crítico em ratos, enquanto Jones et al. (2004) utilizaram a micro-CT para avaliar o reparo ósseo em parede orbitária de porcos. A espessura dos cortes tomográficos eram de 15, 18, 15 e 9,4 $\mu \mathrm{m}$, respectivamente. Lu e Rabie (2003) investigaram a microarquitetura da cicatrização de defeitos de mandíbulas de coelho com uma espessura de corte de $25 \mu \mathrm{m}$. No nosso trabalho foi utilizada uma espessura de corte tomográfico de $16 \mu \mathrm{m}$. 
O procedimento de calibragem (thresholdind) dos valores de cinza correspondente ao tecido ósseo garantiram a análise morfométrica quantitativa do reparo ósseo. Esse método foi utilizado previamente para diferenciar o tecido mineralizado do tecido mole (EFEOGLU, 2009).

O fosfato de cálcio tem um valor na escala de cinza de 116 enquanto o valor do osso da calvária é de aproximadamente 196. Esses valores na escala de cinza correspondem ao índice de atenuação linear dos materiais. Para uma análise quantitativa morfométrica através da micro-CT pode-se separar o fosfato de cálcio do tecido ósseo. Jones et al. (2004) utilizou uma técnica similar de separação que baseava-se na intensidade dos histogramas para diferenciar seus arcabouços poliméricos do tecido ósseo mineralizado.

No presente trabalho foram utilizados o Bio-Oss, composto basicamente de hidroxiapatita bovina, a hidroxiapatita sintética e o tendão mineralizado com fosfato de cálcio. Devido a semelhança química da hidroxiapatita bovina à hidroxiapatita do osso da calvária do animal, não foi possível separar o remanescente do Bio-Oss do tecido ósseo adjacente. A grânulos de hidroxiapatita sintética que estavam em fase de reabsorção no interior do defeito não foram observados na análise de micro-CT, portanto não foram contabilizados como tecido mineralizado. Já o fosfato de cálcio do tendão bovino mineralizado, quando avaliado pela micro-CT, fora totalmente reabsorvido no final do período, o que foi corroborado com os achados da análise histológica.

Poucos estudos tiveram o objetivo de segmentar as biocerâmicas do tecido ósseo através da micro-CT, porém nenhum pode ser considerado preciso (POLAK, 2012). Uma abordagem propôs, na calibração (thresholding), a fixação de uma porcentagem na escala de cinza com o objetivo de diferenciar o tecido mole, o osso e o biomaterial (GAUTHIER, 2005). Na padronização das porcentagens, assume-se diferenças constantes entre esses constituintes. Para o tecido mole e o osso não há problema, pois os índices de atenuação lineares são bem diferentes, e, inclusive, foram empregados nesse estudo. Entretanto, para a comparação entre o material e o osso fica impossibilitada devido as diferenças de atenuação do tecido ósseo durante o processo de reparo. Além do mais, em alguns estágios do reparo tecidual 
há uma inversão na atenuação do osso em mineralização e da biocerâmica em reabsorção (DOERNBERG, 2006).

$\mathrm{Na}$ análise de micro-CT, observamos que o Bio-Oss apresentou maior volume de tecido ósseo significante em relação aos outros materiais, ou seja, as partículas de BioOss se mantiveram no interior do defeito sendo menos reabsorvidas. O enxerto sendo lentamente reabsorvido proporciona, assim, um arcabouço para o crescimento tecidual no seu interior e formação de novo tecido ósseo. Dessa maneira esse biomaterial apresenta melhor propriedade de osteocondução, pois, permanecendo no interior do defeito, ele evita a invaginação do tecido conjuntivo fornecendo andaimes para o crescimento ósseo (Tabela 2).

As biocerâmicas como a hidroxiapatita e o fosfato de cálcio apresentam índices de atenuação similar ao tecido ósseo, o que dificulta bastante a quantificação do crescimento ósseo no seu interior. Isso resulta na dificuldade de se avaliar o material na regeneração de uma forma completa, o que acaba por indicar a utilização de métodos auxiliares menos precisos e invasivos (POLAK, 2012). Outros trabalhos na literatura também desenvolveram algoritmos para a biocerâmicas, porém de uma maneira limitada e imprecisa (DOERNBERG, 2006; GAUTHIER, 2005; LENTHE, 2007). Levando-se em conta essas limitações, o presente trabalho não teve a pretensão de quantificar o crescimento ósseo no interior das amostras.

Quando avaliamos as imagens da micro-CT nos grupos experimentais da hidroxiapatita sintética e do tendão bovino observamos uma intensa reabsorção dos biomateriais e discreta formação de tecido mineralizado, principalmente o grupo do tendão bovino (Figuras 21 e 22). Observar também, na figura 21, o fechamento centrípeto da ferida cirúrgica com margens bastante irregulares, denotando a neoformação óssea. Note também a presença de pontos brancos flutuando no interior do defeito, os quais são imagens do remanescente de hidroxiapatita que já foi quase totalmente reabsorvida, segundo os achados da micro-CT. As bordas laterais do defeito ósseo apresentavam aspecto biselado indicando um pequeno processo de neoformação óssea. Em nenhum dos animais se observou resposta inflamatória exacerbada com reabsorção óssea intensa o que contra indicaria o emprego desses materiais. 
Da mesma maneira, quando analisamos a porcentagem de tecido ósseo, que é uma razão do volume de tecido ósseo pelo total de volume analisado, encontramos a mesma significância. Isso evidencia que o grupo do Bio-Oss apresentou maior quantidade de tecido mineralizado, corroborando aos achados anteriores, e, também, que a análise entre os grupos foi fiel, pois foi selecionada a mesma espessura de tecido para ser analisado em todas as amostras, o que é ajustado manualmente.

Outro parâmetro importante que também foi avaliado pela micro-CT foi a superfície de contato ósseo, que representa a área superficial do tecido mineralizado que está interconectado. A interconectividade do tecido ósseo é um quesito importante, pois o contato entre os grânulos proporciona pontes para o aporte de células osteoblásticas, vasos sanguíneos e o crescimento do tecido duro. Quando comparamos os três materiais observamos que o Bio-Oss apresentou maior superfície de contato estatisticamente significante que a hidroxiapatita, que por sua vez foi maior que o tendão bovino (Gráfico 1).

A superfície de contato ósseo foi utilizada primeiramente para quantificar a reabsorção óssea por Odgaard Agundersen (1993). Cacciafesta et al. (2001) e Verna et al. (2002) utilizaram o volume ósseo e a quantidade de mineralização em termos de valores de cinza para avaliar a regeneração em defeito de tamanho crítico em calvária de ratos, semelhante ao presente estudo. Com o mesmo objetivo, Lutolf et al. (2003) utilizaram a superfície de contato ósseo bem como o volume ósseo para mensurar o reparo ósseo. Jones et al. (2004) utilizaram os dados obtidos através da micro-CT para quantificar o crescimento ósseo interno e modelo de elementos finitos para avaliar o osso regenerado.

A análise de micro-CT forneceu também a densidade de superfície óssea que é a razão da área total da superfície do tecido mineralizado pelo volume total analisado. Esse parâmetro também considera o volume total analisado, o que padroniza todas as amostras. A área superficial do tecido ósseo sempre foi um parâmetro importante na análise morfométrica convencional, porém era obtido através de cortes histológicos seriados em duas dimensões, sendo um procedimento trabalhoso e demorado. O Bio-Oss apresentou maior densidade de superfície óssea estatisticamente significante em relação aos outros materiais, ou seja o grupo 
BioOss apresentou maior área de superfície mineralizada que os outros grupos (Gráfico 1).

Variáveis como densidade de superfície óssea, volume ósseo e superfície de contato ósseo foram calculadas na análise morfométrica quantitativa. $O$ entendimento da diferença das imagens do tecido mineralizado do tecido conjuntivo é fundamental para a verificação dos substitutos ósseos (EFEOGLU, 2007). O grande diferencial desse estudo foi a verificação do volume ósseo, da superfície óssea e da interconectividade do tecido ósseo de uma maneira precisa e não destrutiva.

Um dos resultados mais relevantes do presente estudo foi o desenvolvimento de uma metodologia não invasiva, a qual tem a capacidade de quantificar o tecido mineralizado no sítio em reparo com alta resolução, obtendo imagens bastante elucidativas de uma maneira simples e eficaz. Dessa maneira, quantificando o tecido mineralizado, pode-se comparar materiais e produtos farmacêuticos os quais interagem com o tecido ósseo. Hilderbrand et al. (1999) utilizaram previamente os parâmetros volume ósseo e área de superfície óssea para avaliar amostras ósseas de cadáver. Kurth e Müller (2001) utilizaram os mesmos parâmetros para avaliar os efeitos destrutivos de tumores ósseos e, adicionalmente, definiram uma nova variável chamada quantidade de mineralização, pois devido à resolução não conseguiram discriminar o diferentes tipos de materiais mineralizados presentes no sítio em reparo.

Seguindo essa tendência, os estudos atuais visam empregar métodos minimamente invasivos, ou seja, devem quantificar a regeneração óssea causando o mínimo de morbidade aos animais. Nesse contexto, a utilização de microtomografia computadorizada torna-se uma ótima alternativa quando deseja-se avaliar implantes e estruturas vitais. A grande questão que surge é: a microtomografia computadorizada e a análise histológica são métodos complementares, ou a microCT pode substituir futuramente a análise histológica como uma técnica minimente invasiva. Atualmente sabemos que esses métodos são complementares, mas por questões bioéticas deveríamos desenvolver metodologias que substituam o sacrifício animal. 
Estudos preliminares confirmaram que a micro-CT é uma técnica de fácil reprodução e repetição para avaliação da formação óssea através da análise da mineralização e da microarquitetura óssea (GIELKENS, 2008). Adicionalmente, acreditamos que essa técnica é uma poderosa ferramenta aplicada a engenharia biomédica. Futuramente, será possível monitorar clinicamente os processos degenerativos ósseos e suas terapias de reparação através da tecnologia de microCT. Indubitavelmente, essa técnica de imagem quantitativa em alta resolução será um exame clínico imprescindível para o diagnóstico, tratamento e acompanhamento dos pacientes pelos cirurgiões. 


\section{CONCLUSÕES}

O presente estudo foi eficaz na comparação desses novos materiais experimentais em relação a marca comercial Bio-Oss, avaliando a osteocondução e o comportamento biológico dos materiais no interior do defeito crítico no período avaliado empregando diferentes técnicas de mensuração.

$\mathrm{Na}$ avaliação radiográfica a marca comercial Bio-Oss apresentou melhor osteocodução em relação aos materiais experimentais. Os grânulos de BioOss remanescente foram interpretados como tecido ósseo, devido à sua semelhança estrutural. Os grânulos de hidroxiapatita remanescente não foram detectados radiograficamente e, o tendão bovino mineralizado, foi deveras reabsorvido.

Entretanto, constatamos através da análise histológica que a hidroxiapatita sintética mostrou-se presente no interior do defeito exibindo propriedades osteocondutoras semelhantes a marca comercial Bio-Oss. Já o tendão bovino mineralizado, mais uma vez, não teve boa osteocondução, sendo contra-indicado na manutenção do espaço ósseo.

Quando comparamos os dois métodos constatamos que a micro-CT apresenta baixa especificidade, ou seja, não foi capaz de distinguir o tecido ósseo do Bio-Oss e alta sensibilidade, pois quantifica de uma forma muito precisa os valores com alta resolução. Já a análise histológica consegue distinguir com precisão os materiais e o tecido adjacente, porém não consegue quantificá-los de maneira fácil e precisa.

Portanto, concluímos que a hidroxiapatita sintética tem grande potencial de ser utilizada no preenchimento de defeitos ósseos. Quando comparamos os métodos, constatamos ainda que são complementares e novos aprimoramentos devem ser feitos na técnica de micro-CT para melhorar sua capacidade de distinguir diferentes materiais. 


\section{REFERÊNCIAS ${ }^{1}$}

AGHDASI, B.; MONTGOMERY, S.R.; DAUBS, M.D.; WANG, J.C. (2012). A review of demineralized bone matrices for spinal fusion: the evidence for efficacy. The Surgeon. Disponível em: <http://dx.doi.org/10.1016/j.surge.2012.08.001>. Acesso em: 12 jul. 2012.

AHLMANN, E.; PATZAKIS, M.; ROIDIS, N. Comparison of anterior and posterior iliac crest bone grafts in terms of harvest-site morbidity and functional outcomes. $\mathbf{J}$ Bone Joint Surg Am, v. 84, p. 716-20, 2002.

ALEXANDER, J. M. ; BAB, I.; FISH, S.; MÜLLER, R.; UCHIYAMA, T.; GRONOWICZ, G. Human parathyroid hormone 1-34 reverses bone loss in ovariectomized mice. $\mathbf{J}$ Bone Miner Res, v. 16, p. 1665-73, 2001.

ALT, V.; KÖGELMAIER, D.V.; LIPS, K.S.; WITT, V.; PACHOLKE, S.; HEISS, C.; KAMPSCHULTE, M.; HEINEMANN, S.; HANKE, T.; SCHNETTLER, R.; LANGHEINRICH, A.C. Assessment of angiogenesis in osseointegration of a silicacollagen biomaterial using 3D-nano-CT. Acta Biomaterialia, v. 7, p. 3773-79, 2011.

ANDERSSON, L.; JONES, A.C.; KNACKSTEDT, M.A.; BERGSTRÖM, L. Threedimensional structure analysis by X-ray micro-computed tomography of macroporous alumina templated with expandable microspheres. Journal of the European

Ceramic Society, v. 30, p. 2547-54, 2010.

ANDRADE, M.G.; MOREIRA, D.C.; DANTAS, D.B.; SÁ, C.N.; DE BITTENCOURT, T.C.; SADIGURSKY, M. Pattern of osteogenesis during onlay bone graft healing.

Oral Surg Oral Med Oral Pathol Oral Radiol Endod, v. 110, p. 713-19, 2010.

BALÇIK, C.; TOKDEMIR, T.; SENKÖYLÜ, A.; KO, N.; TIMUÇIN, M.; AKIN. S. Early weight bearing of porous HA/TCP (60/40) ceramics in vivo: a longitudinal study in a segmental bone defect model of rabbit. Acta Biomater, v. 3, p. 985-96, 2007.

BEN-NISSAN, B. Natural bioceramics: from coral to bone and beyond. Current Opinion in Solid State and Materials Science, v. 7, p. 283-88, 2003.

BET, M. R. Preparação e caracterização de biocerâmicas compostas de colágeno e sais de fosfato de Cálcio. Dissertação de Mestrado. Instituto de Química de São Carlos-USP - São Carlos, 1995.

BEZERRA, F. J. Terapia clínica avançada em implantodontia. Ed. Artes Médicas, cap.02, p.21. São Paulo, 2002.

1- De acordo com a Associação Brasileira de Normas Técnicas. NBR: 6023. 
BIELBY, R.; JONES, E.; MCGONAGLE, D. The role of mesenchymal stem cells in maintenance and repair of bone. Injury, v. 38, p. 26-32, 2007.

BLOCK, M.S. Horizontal ridge augmentation using particulate bone. Atlas Oral Maxillofac Surg Clin North Am, v. 14, p. 27-38, 2006.

BLOCK, M.S.; JACKSON. W.C. Techniques for Grafting the Extraction Site in Preparation for Dental Implant Placement. Atlas Oral Maxillofacial Surg Clin N Am, v. 14, p. 1-25, 2006.

BOCCACCINI, A.R.; BLAKER, J.J. Bioactive composite materials for tissue engineering scaffolds. Expert Rev Med Devices, v. 2, p. 303-312, 2005.

BOHNER, M. Calcium orthophosphates in medicine: from ceramics to calcium phosphate cements. Injury, v. 31, p. 37-47, 2000.

BOHNER, M.; VAN LENTHE, G.H.; GRUENENFELDER, S.; HIRSIGER, W.; EVISON, R.; MÜLLER, R. Synthesis and characterization of porous $b$-tricalcium phosphate blocks. Biomaterials, v. 26, p. 6099-105, 2005.

BOHNING B.P.; DAVENPORT, W.D.; JEANSONNE, B.G. The effect of guided tissue regeneration on the healing of osseous defects in rat calvária. J Endod, v. 25, p. 8184, 1999.

BOSCH, C.; MELSEN, B.; VARGERVIK, K. Guided bone regeneration in calvarial bone defects using polythetrafluoroethylene membranes. Cleft Palate Craniofac J, v. 32, p. 311-317, 1995.

BOSCH, C.; MELSEN, B.; VARGERVIK, K. Importance of the critical-size bone defect in testing bone-regenerating materials. J Craniofac Surg, v. 9, p. 310-6, 1998.

BUCK, B.E. Human bone and tissue allografts. Clin Orthop, v. 303, p. 8-17, 1994.

BURG, K.J.L.; PORTER, S.; KELLAM, J.F. Biomaterial development for bone tissue engineering. Biomaterials, v. 21, p. 2347-59, 2000.

BURSTEIN, F.D.; COHEN, S.R.; HUDGINS, R.; BOYDSTON, W. The use of porous granular hydroxyapatite in secondary orbitocranial reconstruction. Plast Reconstr Surg, v. 100, p. 869-74, 1997.

BUSENLECHNER, D.; HUBER, C.D.; VASAK, C.; DOBSAK, A.; GRUBER, R.; WATZEK, G. Sinus augmentation analysis revised: the gradient of graft consolidation. Clin Oral Implants Res, v. 20, p. 1078-83, 2009.

BUSER, D.; DULA, K.; HIRT, H.P.; SCHENK, R.K. Lateral ridge augmentation using autografts and barrier membranes: a clinical study with 40 partially edentulous patients. J Oral Maxillofac Surg, v. 54, p. 420-32, 1996. 
CACCHIOLI, A.; SPAGGIARI, B.; RAVANETTI, F.; MARTINI, F.M.; BORGHETTI, P.; GABBI, C. The critical sized bone defect: morphological study of bone healing. Ann Fac Medic Vet di Parma, v. 26, p. 97-110, 2006.

CACCIAFESTA, V.; DALSTRA, M.; BOSCH, C.; MELSEN, B.; ANDREASSEN, T.T. Growth hormone treatment promotes guided bone regeneration in rat calvarial defects. Eur J Orthod, v. 23, p. 733-40, 2001.

CAI, L.; WANG, Q.; GU, C.; WU, J.; WANG, J.; KANG, N.; HU, J.; XIE, F.; YAN, L.; LIU, X.; CAO, Y.; XIAO, R. Vascular and micro-environmental influences on MSCcoral hydroxyapatite construct-based bone tissue engineering. Biomaterials, v. 32, p. 8497-8505, 2011.

CAREY, L.E. Premixed rapid-setting calcium phosphate composites for bone repair. Biomaterials, v. 26, p. 5002-14, 2005.

CHEN, T.M.; SHIH, C.; LIN, T.F.; LIN, F.H. Reconstruction of calvarial bone defects using an osteoconductive material and post-implantation hyperbaric oxygen treatment. Materials Science and Engineering C, v. 24, p. 855-860, 2004.

CHIAPASCO, M.; CASENTINI, P.; ZANIBONI, M. Bone augmentation procedures in implant dentistry. Int J Oral Maxillofac Implants, v. 24, p. 237-59, 2009.

CHU, T.M.G.; ORTON, D.G.; HOLLISTER, S.J.; FEINBERG, S.E.; HALLORAN, J.W. Mechanical and in vivo performance of hydroxyapatite implants with controlled architectures. Biomaterials, v. 23, p. 1283-93, 2002.

CONVERSE, G.L.; CONRAD, T.L.; MERRILL, C.H.; ROEDER, R.K. Hydroxyapatite whisker-reinforced polyetherketoneketone bone ingrowth scaffolds. Acta

Biomaterialia, v. 6, p. 856-863, 2010.

CORDARO, L.; AMADE, D.S.; CORDARO, M. Clinical results of alveolar ridge augmentation with mandibular bone grafts in partially edentulous patients prior to implant placement. Clin Oral Implants Res, v. 13, p. 103-11, 2002.

COSTA, A.M.; KOBAYASHI, G.S.; BUENO, D.F.; MARTINS, T.M.; FERREIRA, M.C.; PASSOS-BUENO, M.R.; ALONSO, N. An experimental model for the study of craniofacial deformities. Acta Cir Bras, v. 25, p. 264-268, 2010.

CUNHA, S.M. Influência da relação $\mathrm{Ca} / \mathrm{P}$ na formação de fosfatos de Cálcio sinterizados por precipitação homogênea. $17^{\circ}$ Congresso Brasileiro de

Engenharia e Ciências dos Materiais, Foz do Iguaçu, PR, Brasil: 75-86, 2006.

DACULSI, G. Biphasic calcium phosphate concept applied to artificial bone, implant coating and injectable bone substitute. Biomaterials, v. 19, p. 1473-8, 1998.

DACULSI, G. Formation of carbonate-apatite crystals after implantation of calciumphosphate ceramics. Calcif Tissue Int, v. 46, p. 20-7, 1990. 
DAHABREH, Z.; CALORI, G.M.; KANAKARIS, N.K. A cost analysis of treatment of tibial fracture nonunion by bone grafting or bone morphogenetic protein-7. Int Orthop, v. 33, p. 1407-14, 2009.

DE LONG JR, W.G.; EINHORN, T.A.; KOVAL, K.; MCKEE, M.; SMITH, W.;

SANDERS, R. Bone grafts and bone graft substitutes in orthopaedic trauma surgery. A critical analysis. J Bone Jt Surg Am, v. 89, p. 649-58, 2007.

DEVILLE, S.; SAIZ, E.; NALLA, R.K.; TOMSIA, A.P. Freezing as a path to build complex composites. Science, v. 311, p. 515-8, 2006.

DIMITRIOU, R.; MATALIOTAKIS, G.I.; ANGOULES, A.G.; KANAKARIS, N.K.; GIANNOUDIS, P.V. Complications following autologous bone graft harvesting from the iliac crest and using the RIA: A systematic review. Injury, Int J Care Injured, v. 42, p. S3-S15, 2011.

DIMITRIOU, R.; TSIRIDIS, E.; GIANNOUDIS PV. Current concepts of molecular aspects of bone healing. Injury, v. 36, p. 1392-404, 2005.

DINOPOULOS, H.; DIMITRIOU, R.; GIANNOUDIS, P.V. Bone graft substitutes: What are the options? The Surgeon, v. 10, p. 230-239, 2012.

DOERNBERG, M.C.V.; RECHENBERG, B.V.; BOHNER, M.; GRUNENFELDER, S.; LENTHE, G.H.V.; MÜLLER, R. In vivo behavior of calcium phosphate scaffolds with four different pore sizes. Biomaterials, v. 27, p. 5186-98, 2006.

DU, C.; CUI, F.Z.; ZHU, X.D.; GROOT, K. Three-dimensional nano-HAp/collagen matrix loading with osteogenic cells in organ culture. J Biomed Mater Res, v. 44, p. 407-415, 1999.

EASTLUND, T. Infectious disease transmission through cell, tissue, and organ $\backslash$ transplantation: reducing the risk through donor selection. Cell Transplant, v. 4, p. 455-77, 1995.

ECKARDT, H.; DING, M.; LIND, M. Recombinant human vascular endothelial growth factor enhances bone healing in an experimental nonunion model. $\mathbf{J}$ Bone Joint Surg Br, v. 87, p. 1434-8, 2005.

EFEOGLU, C.; BURKE, J.L.; PARSONS, A.J.; AITCHISON, G.A.; SCOTCHFORD, C.; RUDD, C.; VIKRAM, A.; FISHER, S.E. Analysis of calvarial bone defects in rats using microcomputed tomography: potential for a novel composite material and a new quantitative measurement. British Journal of Oral and Maxillofacial Surgery, v. 47 , p. 616-621, 2009.

EFEOGLU, C.; FISHER, S.E.; ERTÜRK, S.; ÖZTOP, F.; GÜNBAY, S.; SIPAHI, A. Quantitative morphometric evaluation of critical size experimental bone defects by microcomputed tomography. British Journal of Oral and Maxillofacial Surgery, v. 45, p. 203-207, 2007. 
EINHORN, T.A. Clinically applied models of bone regeneration in tissue engineering research. Clin Orthop Relat Res, v. 367, p. S59-67, 1999.

ESFAHANI, S.I.R.; KHORASANI, S.N.; LU, Z.; APPLEYARD, R.; ZREIQAT, H. The influence hydroxyapatite nanoparticle shape and size on the properties of biphasic calcium phosphate scaffolds coated with hydroxyapatite-PCL composites.

Biomaterials, v. 31, p. 5498-5509, 2010.

FELDKAMP, L.A.; GOLDSTEIN, S.A.; PARFITT, A.M.; JESION, G.;

KLEEREKOPER, M. The direct examination of three-dimensional bone architecture in vitro by computed tomography. J Bone Miner Res, v. 4, p. 3-11, 1989.

FIERZ, F.C.; BECKMANN, F.; HUSER, M.; IRSEN, S.H.; LEUKERS, B.; WITTE, F.; DEGISTIRICI, O.; ANDRONACHE, A.; THIE, M.; MÜLLER, B. The morphology of anisotropic 3D-printed hydroxyapatite scaffolds. Biomaterials, v. 29, p. 3799-3806, 2008.

FINKEMEIER, C.G. Bone-grafting and bone-graft substitutes. J Bone Jt Surg Am, v. 84, p. 454-64, 2002.

FURLANETO, F.A., NAGATA, M.J., FUCINI, S.E., DELIBERADOR, T.M., OKAMOTO, T., MESSORA, M.R. Bone healing in critical-size defects treated with bioactive glass/calcium sulfate: a histologic and histometric study in rat calvaria. Clin Oral Implants Res, v. 18, p. 311-8, 2007.

GAUTHIER, O.; MÜLLER, R.; VON STECHOW, D.; LAMY, B.; WEISS, P.; BOULER, J.M. In vivo regeneration with injectable calcium phosphate biomaterial: a threedimensional micro-computed tomographic, biomechanical and SEM study.

Biomaterials, v. 26, p. 5444-53, 2005.

GERBER, H.P.; FERRARA, N. Angiogenesis and bone growth. Trends Cardiovasc Med, v. 10, p. 223-228, 2000.

GHOSH, S.K.; NANDI, S.K.; KUNDU, B.; DATTA, S.; DE, D.K.; ROY, S.K. In vivo response of porous $\mathrm{HA}$ and $\mathrm{B}$-TCP prepared by aqueous solution combustion method and comparison with bioglass scaffolds. J Biomed Mater Res B Appl Biomater, v. 86, p. 217-27, 2008.

GIANNOUDIS, P.V.; DINOPOULOS, H.; TSIRIDIS, E. Bone substitutes: an update. Injury, v. 36, p. 20-7, 2005.

GIELKENS, P.F.; SCHORTINGHUIS, J.; DE JONG, J.R. A comparison of micro-CT, microradiography and histomorphometry in bone research. Arch Oral Biol, v. 53, p. 558-66, 2008.

GREENWALD, A.S.; BODEN, S.D.; GOLDBERG, V.M. American Academy of Orthopaedic Surgeons. The Committee on Biological Implants. Bone-graft substitutes: facts, fictions, and applications. J Bone Joint Surg Am, v. 83, p. 98-103, 2001. 
GULDBERG, R.E.; DUVALL, C.L.; PEISTER, A.; OEST, M.E.; LIN, A.S.P.; PALMER, A.W.; LEVENSTON, M.E. 3D imaging of tissue integration with porous biomaterials. Biomaterials, v. 29, p. 3757-3761, 2008.

GULDBERG, R.E.; LIN, A.S.; COLEMAN, R.; ROBERTSON, G.; DUVALL, C. Microcomputed tomography imaging of skeletal development and growth. Birth Defects Res C Embryo Today, v. 72, p. 250-9, 2004.

HANDA, T.; ANADA, T.; HONDA, Y.; YAMAZAKI, H.; KOBAYASHI, K.; KANDA, N.; KAMAKURA, S.; ECHIGO, S.; SUZUKI, O. The effect of an octacalcium phosphate co-precipitated gelatin composite on the repair of critical-sized rat calvarial defects.

Acta Biomaterialia, v. 8, p. 1190-1200, 2012.

HANKS. T.; ATKINSON, B.L. Comparison of cell viability on anorganic bone matrix with or without P-15 cell binding peptide. Biomaterials, 25: 4831-40, 2004.

HAK, D.J. The use of osteoconductive bone graft substitutes in orthopaedic trauma. J Am Acad Orthop Surg, v. 15, p. 525-36, 2007.

HAUSMAN, M.R.; SCHAFFLER, M.B.; MAJESKA, R.J. Prevention of fracture healing in rats by an inhibitor of angiogenesis. Bone, v. 29, p. 560-564, 2001.

HE, H.; YAN, W.; CHEN, G.; LU, Z. Acceleration of de novo bone formation with a novel bioabsorbable film: a histomorphometric study in vivo. J Oral Pathol Med, v. 37, p. 378-382, 2008.

HEMPEL, U.; REINSTORF, A.; POPPE, M.; FISCHER, U.; GELINSKY, M., POPME, W. Proliferation and differentiation of osteoblasts on biocement $D$ modified with collagen type I and citric acid. J Biomed Mater Res B, v. 71, p. 130-43, 2004.

HENCH, L.L. Bioceramics: from concept to clinic. J Am Ceram Soc, v. 74, p. 1487510, 1991.

HENCH, L.L. Bioactive materials: the potential for tissue regeneration. J Biomed Mater Res, v. 15, p. 511-8, 1998.

HENCH, L.L.; POLAK, J.M. Third-generation biomedical materials. Science, v. 295, p. 1014-7, 2002.

HILDERBRAND, T.; LAIB, A; MÜLLER, R.; DEQUEKER, J.; RÜEGSEGGER, P. Direct three-dimensional morphometric analysis of human cancellous bone: microstructural data from spine, femur, iliac crest, and calceneus. J Bone Miner Res, v. 14, p. 1167-75, 1999.

HO, S.T.; HUTMACHER, D.W. A comparison of micro CT with other techniques used in the characterization of scaffolds. Biomaterials, v. 27, p. 1362-76, 2006.

HOLLISTER, S.J.; LIN, C.Y.; SAITO, E.; LIN, C.Y., SCHEK, R.D.; TABOAS, J.M. Engineering craniofacial scaffolds. Orthod Craniofac Res, v. 8, p. 162-73, 2005. 
HOLTZCLAW, D.; TOSCANO, N.; EISENLOHR, L. The safety of bone allografts used in dentistry: a review. J Am Dent Assoc, v. 139, p. 1192-99, 2008.

HUH, J.Y.; CHOI, B.H.; KIM, B.Y.; LEE, S.H.; ZHU, S.J.; JUNG, J.H. Critical size defect in the canine mandible. Oral Surg Oral Med Oral Pathol Oral Radiol Endod, v. 100, p. 296-301, 2005.

ITOH, S. Implantation study of a novel hydroxyapatite / collagen composite into weight- bearing sites of dogs. Int J Biomed Mat Res, v. 63, p. 507-15, 2002.

JENSEN, S.S.; TERHEYDEN, H. Bone augmentation procedures in localized defects in the alveolar ridge: clinical results with different bone grafts and bone-substitutes materials. Int J Oral Maxillofac Implants, v. 24, p. 218-36, 2009.

JENSEN, T.; SCHOU, S.; STAVROPOULOS, A.; TERHEYDEN, H.; HOLMSTRUP, $P$. Maxillary sinus floor augmentation with Bio-Oss or Bio-Oss mixed with autogenous bone as graft in animals: a systematic review. Int J Oral Maxillofac Surg, v. 41, p. 114-120, 2012.

JIANG, Z.Q.; LIU, H.Y.; ZHANG, L.P.; WU, Z.Q.; SHANG, D.Z. Repair of calvarial defects in rabbits with platelet-rich plasma as the scaffold for carrying bone marrow stromal cells. Oral Surg Oral Med Oral Pathol Oral Radiol, v. 113, p. 327-333, 2012.

JONES, A.C.; ARNS, C.H.; SHEPPARD, A.P.; HUTMACHER, D.W.; MILTHORPE, B.K.; KNACKSTEDT, M.A. Assessment of bone ingrowth into porous biomaterials using MICRO-CT. Biomaterials, v. 28, p. 2491-2504, 2007.

JONES, A.C.; MILTHORPE, B.; AVERDUNK, H.; LIMAYE, A.; SENDEN, T.J.; SAKELLARIOU, A. Qualitative and quantitative analysis of 3D bone ingrowth into polymer scaffolds via micro-computed tomography. Biomaterials, v. 25, p. 4947-54, 2004.

JONES, A.C.; SAKELLARIOU, A.; LIMAYE, A.; ARNS, C.H.; SENDEN, T.J.; SAWKINS, T. Investigation of microstructural features in regenerating bone using micro-computed Tomography. J Mater Sci Mater Med, v. 15, p. 529-32, 2004.

KARAGEORGIOU, V.; KAPLAN, D. Porosity of 3D biomaterial scaffolds and osteogenesis. Biomaterials, v. 26, p. 5474-91, 2005.

KERAMARIS, N.C.; CALORI, G.M.; NIKOLAOU, V.S.; SCHEMITSCH, E.H.; GIANNOUDIS, P.V. Fracture vascularity and bone healing: a systematic review of the role of VEGF. Injury, v. 39, p. 45-57, 2008.

KHAN, S.N.; CAMMISA JR, F.P.; SANDHU, H.S. The biology of bone grafting. J Am Acad Orthop Surg, v. 13, p. 77-86, 2005.

KIKUCHI, M. Self-organization mechanism in a bone-like hydroxyapatite/ collagen nanocomposites synthetised in vitro and its biological reaction in vivo. Biomaterials, v. 22, p. 1705-11, 2001. 
KIM, H.M. Bioactive ceramics: challenges and perspectives. J Ceram Soc Jpn, v. 109, p. S49-57, 2001.

KIM, H.M. Ceramic bioactivity and related biomimetic strategy. Current Opinion in Solid State and Materials Science, v. 7, p. 289-299, 2003.

KIM, M.G.; SHIN, D.M.; LEE, S.W. The healing of critical-sized bone defect of rat zygomatic arch with particulate bone graft and bone morphogenetic protein-2.

Journal of Plastic, Reconstructive \& Aesthetic Surgery, v. 63, p. 459-466, 2010.

KIRSCHBAUER, K. G. Mineralização in vitro de matrizes colagênicas derivadas de tendões calcâneos bovinos e de avestruz. Dissertação de Mestrado. Instituto de Química de São Carlos - USP - São Carlos, 2009..

KITSUGI, T.; YAMAMURO, T.; NAKAMURA, T. Analysis of A-W glass-ceramic surface by micro-beam X-ray diffraction. J Biomed Mater Res, v. 24, p. 259-73, 1990.

KNACKSTEDT, M.A.; ARNS, C.H.; SENDEN, T.J.; GROSS, K. Structure and properties of clinical coralline implants measured via 3D imaging and analysis. Biomaterials, v. 27, p. 2776-86, 2006.

KOKUBO, T.; KIM, H.M.; KAWASHITA, M. Novel bioactive materials with different mechanical properties. Biomaterials, v. 24, p. 2161-75, 2003.

KOCHI, G.; SATO, S.; FUKUYAMA, T.; MORITA, C.; HONDA, K.; ARAI, Y.; ITO, K. Analysis on the guided bone augmentation in the rat calvarium using a microfocus computerized tomography analysis. Oral Surg Oral Med Oral Pathol Oral Radiol Endod, v. 107, p. 42-48, 2009.

KRAMER, F.J.; SINIKOVIC, B.; MULLER, M.; RAHMSTORF, M.; SCHIERLE, H. Experimental application of a biomaterial in bifocal transport osteogenesis for craniofacial reconstruction. Journal of Cranio-Maxillofacial Surgery, v. 36, p. 218226, 2008.

KURTH, A.A.; MÜLLER, R. The effect of an osteolithic tumor on the threedimensional trabecular bone morphology in an animal model. Skeletal Radiol, v. 30, p. 94-8, 2001.

KWEON, H.Y.; LEE, K.G.; CHAE, C.H.; BALÁZSI, C.; MIN, S.K.; KIM, J.Y.; CHOI, G.Y.; KIM, S.G. Development of nano-hydroxyapatite graft with silk fibroin scaffold as a new bone substitute. J Oral Maxillofac Surg, v. 69, p. 1578-1586, 2011.

LARSSON, S. Calcium phosphates: what is the evidence? Journal of Orthopedic Trauma, v. 24, p. 541-5, 2010.

LAURENCIN, C.; KHAN, Y.; EL-AMIN, S.F. Bone graft substitutes. Expert Rev Med Devices, v. 3, p. 49-57, 2006. 
LAWSON, A.C.; CZERNUSZKA, J.T. Collagen-calcium phosphate composites. Proc Inst Mech Eng H, v. 212, p. 413-25, 1998.

LEE, D.W.; KOO, K.T.; SEOL, Y.J.; LEE, M.Y.; KU, Y.; RHYU, I.C.; CHUNG, C.P.; KIM, T.I. Bone regeneration effects of human allogenous bone substitutes: a preliminary study. J Periodontal Implant Sci, v. 40, p. 132-138, 2010.

LEGEROS, R.Z. Properties of osteoconductive biomateials: calcium phosphates. Clin Orthop Rel Res, v. 395, p. 81-98, 2002.

LENTHE, G.H.V.; HAGENMÜLLER, H.; BOHNER, M.; HOLLISTER, S.J.; MEINEL, L.; MÜLLER, R. Nondestructive micro-computed tomography for biological imaging and quantification of scaffold-bone interaction in vivo. Biomaterials, v. 28, p. 24792490, 2007.

LI, Y.; DÅNMARK, S.; EDLUND, U.; WISTRAND, A.F.; HE, X.; NORGÅRD, M.; BLOMÉN, E.; HULTENBY, K.; ANDERSSON, G.; LINDGREN, U. Resveratrolconjugated poly-e-caprolactone facilitates in vitro mineralization and in vivo bone regeneration. Acta Biomater, v. 7, p. 751-758, 2011.

LIN, A.S.; BARROWS, T.H.; CARTMELL, S.H.; GULDBERG, R.E. Microarchitectural and mechanical characterization of oriented porous polymer scaffolds. Biomaterials, v. 24, p. $481-9,2003$.

LINDE, A. Creation of new bone by an osteopromotive membrane technique. An experimental study in rats. J Oral Maxillofac Surg, v. 51, p. 892-97, 1993.

LINDHE, J.; KARRING, T.; LANG, N.P. Tratado de periodontia clínica e implantologia oral. 4ed. Rio de Janeiro: Guanabara Koogan, 2005.

LU, J. The biodegradation mechanism of calcium phosphate biomaterials in bone. $\mathbf{J}$ Biomed Mater Res, v. 63, p. 408-412, 2002.

LU, M.; RABBIE, A.B.M. Microarchitecture of rabbit mandibular defects grafted with intramembraneous or endochondral bone shown by microcomputed tomography. $\mathbf{B r}$ J Oral Maxillofac Surg, v. 41, p. 385-91, 2003.

LU, M.; RABBIE, A.B.M. Quantitative assessment of early healing of intramembranousand endochondral autogenous bone grafts using micro-computed tomography and Q-Win image analyzer. Int J Oral Maxillofac Surg, v. 33, p. 369376, 2004.

LUVIZUTO, E.R.; TANGL, S.; ZANONI, G.; OKAMOTO, T.; SONODA, C.K.; GRUBER, R.; OKAMOTO, R. The effect of BMP-2 on the osteoconductive properties of b-tricalcium phosphate in rat calvaria defects. Biomaterials, v. 32, p. 3855-3861, 2011.

LUTOLF, M.P.; WEBER, F.E.; SCHMOEKEL, H.G. Repair of bone defects using synthetic mimetics of collageneous extracellular matrices. Nat Biotechnol, v. 21, p. 513-8, 2003. 
MALMSTRÖM, J. Bone response inside free-form fabricated macroporous hydroxyapatite scaffolds with and without open microporosity. Clin Implant Dent Relat Res, v. 9, p. 79-88, 2007.

MANGANO, C.; SCARANO, A.; PERROTTI, V.; IEZZI, G.; PIATTELLI, A. Maxillary sinus augmentation with a porous synthetic hydroxyapatite and bovine-derived hydroxyapatite: a comparative clinical and histologic study. Int $\mathbf{J}$ Oral Maxillofac Implants, v. 22, p. 980-6, 2007.

MASTROGIACOMO, M.; PAPADIMITROPOULOS, A.; CEDOLA, A.; PEYRIN, F.; GIANNONI, P.; PEARCE, S.G.; ALINI, M.; GIANNINI, C.; GUAGLIARDI, A.; CANCEDDA, R. Engineering of bone using bone marrow stromal cells and a siliconstabilized tricalcium phosphate bioceramic: evidence for a coupling between bone formation and scaffold resorption. Biomaterials, v. 28, p. 1376-84, 2007.

MCALLISTER, B.S.; MARGOLIN, M.D.; COGAN, A.G.; BUCK, D.; HOLLINGER, J.O.; LYNCH, S.E. Eighteen-month radiographic and histologic evaluation of sinus grafting with anorganic bovine bone in the chimpanzee. Int $\mathbf{J}$ Oral Maxillofac Implants, v. 14, p. 361-8, 1999.

MCCARTHY, C.; PATEL, R.R.; WRAGG, P.F.; BROOK, I.M. Dental implants and onlay bone grafts in the anterior maxilla: analysis of clinical outcome. Int JOral Maxillofac Implants, v. 18, p. 238-41, 2003.

MCCOY, G. Recognizing and managing parafunction in the reconstruction and maintenance of the oral implant patient. Implant Dent, v. 11, p. 19-27, 2002.

MEADS, B.M.; SCOUGALL, P.J.; HARGREAVES, I.C. Wrist arthrodesis using a Synthes wrist fusion plate. J Hand Surg Br, v. 28, p. 571-4, 2003.

MICLAU, T.; HELMS, J.A. Molecular aspects of fracture healing. Current Opinion In Orthopedics, v. 11, p. 367-371, 2000.

MIRANDA, P.; PAJARES, A.; SAIZ, E.; TOMSIA, A.P.; GUIBERTEAU, F. Fracture modes under uniaxial compression in hydroxyapatite scaffolds fabricated by robocasting. J Biomed Mater Res, v. 83A, p. 646-55, 2007.

MIRANDA, P.; PAJARES, A.; SAIZ, E.; TOMSIA, A.P.; GUIBERTEAU, F. Mechanical properties of calcium phosphate scaffolds fabricated by robocasting. J Biomed Mater Res, v. 85A, p. 218-27, 2008.

MOGHADAM, H.G; SÁNDOR, G.K.B.; HOLMES, H.H.I.; CLOKIE, C.M.L. Histomorfometric evaluation of bone regeneration using allogeneic and alloplastic bone substitutes. Journal of Oral Maxillofacial Surgery, v. 62, p. 202-213, 2004.

MOREAU, J.L.; WEIR, M.D.; XU, H.H.K. Self-setting collagen-calcium phosphate cement: mechanical and cellular properties. J Biomed Mater Res A, v. 91, p. 60513, 2009. 
MOREIRA, P.L.; AN, Y.H.; SANTOS JR, A.R.; GENARI, S.C. In Vitro Analysis Of Anionic Collagen Scaffolds For Bone Repair. J Biomed Mater Res Part B: Appl Biomater, v. 71B, p. 229-237, 2004.

MORONI, A.; PEGREFFI, F.; CADOSSI, M.; HOANG-KIM, A.; LIO, V.; GIANNINI, S. Hydroxyapatite-coated external fixation pins. Expert Rev Med Devices, v. 2, p. 46571, 2005.

MUNAR, M.L. Effects of sintering temperature over 1,300 degrees $C$ on the physical and compositional properties of porous hydroxyapatite foam. Dent Mater J, v. 25, p. 1-13, 2006.

NAGAHARA, K. Osteogenesis of hydroxyapatite and trcalcium phosphate used as bone substitute. Int j Oral Maxillof Implants, v. 7, p. 72-9, 1992.

NANDI, S.K.; KUNDU, B.; GHOSH, S.K. Efficacy of nano-hydroxyapatite prepared by an aqueous solution combustion technique in healing bone defects of goat. $\mathbf{J}$ Vet Sci, v. 9, p. 183-91, 2008.

NANDI, S.K.; ROY, S.; MUKHERJEE, P.; KUNDU, B., DE, D.K.; BASU, D. Orthopaedic applications of bone graft \& graft substitutes: a review. Indian J Med Res, v. 132, p. 15-30, 2010.

NEO, M.; KOTAMI, S.; NAKAMURA, T.; YAMAMURO, T.; OHTSUKI, C. KOKUBO, T. A comparative study of ultrastructure of the interface between four kinds of surface active ceramic and bone. J Biomed Mater Res, v. 26, p. 1419-32, 1992.

NEVINS, M.L.; CAMELO, M.; LYNCH, S.E. Evaluation of periodontal regeneration following grafting intrabony defects with bio-oss collagen: a human histologic report. Int J Periodontics Restorative Dent, v. 23, p. 9-18, 2003.

NGUYEN, H.Q.; DEPORTER, D.A.; PILLIAR, R.M.; Valiquette, N.; Yakubovich, R. The effect of sol-gel-formed calcium phosphate coatings on bone ingrowth and osteoconductivity of porous-surfaced Ti alloy implants. Biomaterials, v. 25, p. 86576, 2004.

NIEMELÄ, T.; AYDOGAN, D.B.; HANNULA, M.; HYTTINEN, J.; KELLOMÄKI, M. Determination of bioceramic filler distribution and porosity of self-reinforced bioabsorbable composites using micro-computed tomography. Composites: Part A, v. 42, p. 534-542, 2011.

NKENKE, E.; STELZLE, F. Clinical outcomes of sinus floor augmentation for implant placement using autogenous bone or bone substitutes: a systematic review. Clin Oral Implants Res, v. 20, p. 124-33, 2009.

NOTODIHARDJO, F.Z.; KAKUDO, N.; KUSHIDA, S.; SUZUKI, K.; KUSUMOTO, K. Bone regeneration with BMP-2 and hydroxyapatite in critical-size calvarial defects in rats. Journal of Cranio-Maxillo-Facial Surgery, v. 40, p. 287-291, 2012. 
ODGAARD AGUNDERSEN, H.J. Quantification of connectivity in cancellous bone, with special emphasis on 3-D reconstructions. Bone, v. 14, p. 173-82, 1993.

OEST, M.E.; DUPONT, K.M.; KONG, H.J.; MOONEY, D.J.; GULDBERG, R.E. Quantitative assessment of scaffold and growth factor-mediated repair of critically sized bone defects. J Orthop Res, v. 25, p. 941-50, 2007.

OGAWA, C.A.; PLEPIS, A.M.G. Estudos preliminares de liberação de ciprofloxacina em compósito de hidroxiapatita: colágeno. Revista Brasileira de Engenharia Biomédica, v. 17, p. 123-30, 2001.

O'HARA, R.M.; ORR, J.F.; BUCHANAN, F.J.; WILCOX, R.; BARTON, D.; DUNNE, $\mathrm{N}$. Development of a bovine collagen-apatitic calcium phosphate cement for potential fracture treatment through vertebroplasty. Acta Biomater (2012), In Press: http://dx.doi.org/10.1016/j.actbio.2012.07.003

OHURA, K. Bone-bonding abitity of $\mathrm{P}_{2} \mathrm{O}_{5}-$ free $\mathrm{CaOSiO}_{2}$ glasses. J Biomed Mater Res, v. 25, p. 1363-70, 1991.

OLIVEIRA, A.L.; MALAFAYA, P.B.; COSTA, S.A.; SOUSA, R.A.; REIS, R.L. Microcomputed tomography (micro-CT) as a potential tool to assess the effect of dynamic coating routes on the formation of biomimetic apatite layers on 3D-plotted biodegradable polymeric scaffolds. J Mater Sci Mater Med, v. 18, p. 211-23, 2007.

O'NEILL, K.R.; STUTZ, C.M.; MIGNEMI, N.A.; BURNS, M.C.; MURRY, M.R.; NYMAN, J.S.; SCHOENECKER, J.G. Micro-computed tomography assessment of the progression of fracture healing in mice. Bone, v. 50, p. 1357-1367, 2012.

OSAKA, A. Calcium apatite prepared from calcium hydroxide and orthophosphoric acid. J Mat Sci, v. 2, p. 51-55, 1991.

OTSUKI, B.; TAKEMOTO, M.; FUJIBAYASHI, S.; NEO, M.; KOKUBO, T.; NAKAMURA, T. Pore throat size and connectivity determine bone and tissue ingrowth into porous implants: three dimensional micro-CT based structural analyses of porous bioactive titanium implants. Biomaterials, v. 27, p. 5892-900, 2006.

PALLESEN, L.; SCHOU, S.; AABOE, M. Influence of particle size of autogenous bone grafts on the early stages of bone regeneration: A histologic and stereologic study in rabbit calvarium. Int J Oral Maxillofac Implants, v. 17, p. 498-508, 2002.

PARFITT, A.M.; MATHEWS, C.H.; VILLANUEVA, A.R.; KLEEREKOPER, M.; FRAME, B.; RAO, D.S. Relationships between surface, volume, and thickness of iliac trabecular bone in aging and in osteoporosis. Implications for the microanatomic and cellular mechanisms of bone loss. J Clin Invest, v. 72, p. 1396-409, 1983.

PARK, J. Biomaterials Science and Engineering, Plenum Press, New York, 1984. 
PELISSIER, P.; VILLARS, F.; MATHOULIN-PELISSIER, S.; BAREILLE, R.; LAFAGE-PROUST, M.H.; VILAMITJANA-AMEDEE, J. Influences of vascularization and osteogenic cells on heterotopic bone formation within a madreporic ceramic in rats. Plast. Reconstr Surg, v. 111, p. 1932-1941, 2003.

PIERI, F.; LUCARELLI, E.; CORINALDESI, G.; ALDINI, N.N.; FINI, M.; PARRILLI, A.; DOZZA, B.; DONATI, D.; MARCHETTI, C. Dose-dependent effect of adipose-derived adult stem cells on vertical bone regeneration in rabbit calvarium. Biomaterials, $v$. 31, p. 3527-35, 2010.

PILLIAR R.M.; FILIAGGI, M.J.; WELLS, J.D.; GRYNPAS, M.D.; KANDEL, R.A. Porous calcium polyphosphate scaffolds for bone substitute applications - in vitro characterization. Biomaterials, v. 22, p. 963-72, 2001.

POLAK, S.J.; CANDIDO, S.; LEVENGOOD, S.K.L.; JOHNSON, A.J.W. Automated segmentation of micro-CT images of bone formation in calcium phosphate scaffolds. Computerized Medical Imaging and Graphics, v. 36, p. 54-65, 2012.

PORTER, B.D.; LIN, A.S.; PEISTER, A.; HUTMACHER, D.; GULDBERG, R.E. Noninvasive image analysis of $3 \mathrm{D}$ construct mineralization in a perfusion bioreactor. Biomaterials, v. 28, p. 2525-33, 2007.

PORTER, B.D.; ZAUEL, R.; STOCKMAN, H.; GULDBERG, R.; FYHRIE, D. 3-D computational modeling of media flow through scaffolds in a perfusion bioreactor. $\mathbf{J}$ Biomech, v. 38, p. 543-9, 2005.

PRIPATNANONT, P.; NUNTANARANONT, T.; VONGVATCHARANON, S.; LIMLERTMONGKOL, S. Osteoconductive effects of 3 heat-treated hydroxyapatites in rabbit calvarial defects. J Oral Maxillofac Surg, v. 65, p. 2418-2424, 2007.

REICHERT, J.C.; SAIFZADEH, S.; WULLSCHLEGER, M.E.; EPARI, D.R.; SCHÜTZ, M.A.; DUDA, G.N.; SCHELL, H.; GRIENSVEN, M.V.; REDL, H.; HUTMACHER, D.W. The challenge of establishing preclinical models for segmental bone defect research. Biomaterials, v. 30, p. 2149-2163, 2009.

RENGHINI, C.; KOMLEV, V.; FIORI, F.; VERNE, E.; BAINO, F.; BROVARONE, C.V. Micro-CT studies on 3-D bioactive glass-ceramic scaffolds for bone regeneration. Acta Biomaterialia, v. 5, p. 1328-1337, 2009.

REYNOLDS, M.A.; AICHELMANN-REIDY, M.E.; BRANCH-MAYS, G.L. Regeneration of Periodontal Tissue: Bone Replacement Grafts. Dent Clin N Am, v. 54, p. 55-71, 2010.

ROCHA, L.B.; GOISSIS, G.; ROSSI, M.A. Biocompatibility of anionic collagen matrix as scaffold for bone healing. Biomaterials, v. 23, p. 449-456, 2002.

RODRIGUES, C.V.M.; SERRICELLA, P.; LINHARES, A.B.R.; GUERDES, R.M.; BOROJEVIC, R.; ROSSI, M.A. Characterization of a bovine collagen-hydroxyapatite composite scaffold for tissue engineering. Biomaterials, v. 24, p. 4987-97, 2003. 
ROSE, F.R.; HOU, Q.; OREFFO, R.O. Delivery systems for bone growth factors the new players in skeletal regeneration. J Pharm Pharmacol, v. 56, p. 415-27, 2004.

ROSEN, V.B.; HOBBS, L.W.; SPECTOR, M. The ultrastructure of anorganic bovine bone and selected synthetic hydroxyapatites used as bone graft substitute materials. Biomaterials, v. 23, p. 921-28, 2002.

RÜEGSEGGER, P.; KOLLER, B.; MÜLLER, R. A microtomographic system for the nondestructive evaluation of bone architecture. Calcif Tissue Int, v. 58, p. 24-9, 1996.

RUEHE, B.; NIEHUES, S.; HEBERER, S.; NELSON, K. Miniature pigs as an animal modelfor implant research: bone regeneration in critical-size defects. Oral Surg. Oral Med Oral Pathol Oral Radiol Endod, v. 108, p. 699-706, 2009.

SANCHEZ-SOTELO, J.; MUNUERA, L.; MADERO, R. Treatment of fractures of the distal radius with remodellable bone cement: a prospective, randomised study using Norian SRS. J Bone Jt Surg Br, v. 82, p. 856-63, 2000.

SCHEER, J.H.; ADOLFSSON, L.E. Tricalcium phosphate bone substitute in corrective osteotomy of the distal radius. Injury, v. 40, p. 262-267, 2009.

SCHLEGEL, K.A.; FICHTNER, G.; SCHULTZE-MOSGAU, S.; WILTFANG, J. Histologic findings in sinus augmentation with autogenous bone chips versus a bovine bone substitute. Int J Oral Maxillofac Implants, v. 18, p. 53-8, 2003.

SCHLEGEL, K.A.; LANG, F.J.; DONATH, K.; KULOW, J.T.; WILTFANG, J. The monocortical critical size bone defect as an alternative experimental model in testing bone substitute materials. Oral Surg Oral Med Oral Pathol Oral Radiol Endod, v. 102, p. 7-13, 2006.

SCHMITZ, J.P.; SCHWARTZ, Z.; HOLLINGER, J.O.; BOYAN, B.D. Characterization of rat calvarial nonunion defects. Acta Anat (Basel), v. 138, p. 185-192, 2009.

SCHWARTZ, C.E.; MARTHA, J.F.; KOWALSKI, P. Prospective evaluation of chronic pain associated with posterior autologous iliac crest bone graft harvest and its effect on postoperative outcome. Health Qual Life Outcomes, v. 7, p. 49-59, 2009.

SIMON, J.L.; ROY, T.D.; PARSONS, J.R.; REKOW, E.D.; THOMPSON, V.P.; KEMNITZER, J. Engineered cellular response to scaffold architecture in a rabbit trephine defect. J Biomed Mater Res, v. 66A, p. 275-82, 2003.

SODEK, K.L.; TUPY, J.H.; SODEK, J.; GRYNPAS, M.D. Relationships between bone protein and mineral in developing porcine long bone and calvaria. Bone, v. 26, p. 189-98, 2000.

SOHIER, J.; DACULSI, G.; SOURICE, S.; DE GROOT, K.; LAYROLLE, P. Porous beta tricalcium phosphate scaffolds used as a BMP-2 delivery system for bone tissue engineering. J Biomed Mater Res, v. 92A, p. 1105-14, 2009. 
STAFFA, G.; NATALONI, A.; COMPAGNONE, C. Custom made cranioplasty prostheses in porous hydroxy-apatite using 3D design techniques: 7 years experience in 25 patients. Acta Neurochir, v. 149, p. 161-70, 2007.

TADIC, D.; EPPLE, M. A thorough physicochemical characterization of 14 calcium phosphate-based bone substitution materials in comparison to natural bone.

Biomaterials, v. 25, p. 987-994, 2004.

TAGA, R. Autogenous and allogenous bone graft placed in the guinea pig critical size calvaria defect. Rev Bras Cir Implant, v. 7, p. 37-44, 2000.

TAMAI, N.; MYOUI, A.; TOMITA, T.; NAKASE, T.; TANAKA, J.; OCHI, T. Novel hydroxyapatite ceramics with an interconnective porous structure exhibit superior osteoconduction in vivo. J Biomed Mater Res, v. 59, p. 110-7, 2002.

TAMIMI, F.; BALAMURUGAN, K.; DOILLON, C.; GBURECK, U.; LE NIHOUANNEN, D.; LOPEZ CABARCOS, E. Brushite-collagen composites for bone regeneration. Acta Biomater, v. 4, p. 1315-21, 2008.

TERHEYDEN, H.; JEPSEN, S.; MÖLLER, B.; TUCKER, M.M.; RUEGER, D.C. Sinus floor augmentation with simultaneous placement of dental implants using a combination of deproteinized bone xenografts and recombinant human osteogenic protein-1. A histometric study in miniature pigs. Clin Oral Implants Res, v. 10, p. 510-21, 1999.

THOMAS, M.V.; PULEO, D.A. Calcium sulfate: Properties and clinical applications. J Biomed Mater Res B Appl Biomater, v. 88, p. 597-610, 2009.

URIST, M.R. Bone Formation by autoinduction. Science, v. 150, p. 893-899, 1965.

URIST; M.R.; LIETZE, A.; DAWSON, E. Beta-tricalcium phosphate delivery system for bone morphogenetic protein. Clin Orthop Relat Res, v. 187, p. 277-84, 1984.

VAL, J.E.M.S.; GUIRADO, J.L.C.; RUIZ, R.A.D.; FERNANDEZ, M.P.R.; MARTINEZ, I.M.; MARIN, J.M.G.; NEGRI, B.; GARCIA, F.C.; GONZALEZ, J.M.M.; AZA, P.N. New block graft of a-TCP with silicon in critical size defects in rabbits: chemical characterization, histological, histomorphometric and micro-CT study. Ceramics International, v. 38, p. 1563-1570, 2012.

VERNA, C.; DALSTRA, M.; WIKESJÖ, U.M.; TROMBELLI, L.; BOSCH, C. Healing patterns in calvarial bone defects following guided bone regeneration in rats. A microCT scan analysis. J Clin Periodontol, v. 29, p. 865-70, 2002.

VIDEAU, J. J.; DUPUIS, V. Phosphates and biomaterials. Eur J State Inorg Chem, v. 28, p. 303-343, 1991.

WAHL, D.A.; CZERNUSZKA, J.T. Collagen-hydroxyapatite composites for hard tissue repair. Eur Cell Mater, v. 11, p. 43-56, 2006. 
WANG, C.; DUAN, Y.; MARKOVIC, B. Proliferation and bone related gene expression of osteoblasts grown on hydroxyapatite ceramics sintered at different temperatures. Biomaterials, v. 25, p. 2949-56, 2004.

WEISS, P.; LAYROLLE, P.; CLERGEAU, L.P.; ENCKEL, B.; PILET, P.; AMOURIQ, Y.; DACULSI, G.; GIUMELLI, B. The safety and efficacy of an injectable bone substitute in dental sockets demonstrated in a human clinical trial. Biomaterials, v. 28, p. 3295-3305, 2007.

WEISS, P.; OBADIA, L.; MAGNE, D.; BOURGES, X.; RAU, C., WEITKAMP, T. Synchrotron X-ray microtomography (on a micron scale) provides three-dimensional imaging representation of bone ingrowth in calcium phosphate biomaterials.

Biomaterials, v. 24, p. 4591-601, 2003.

WEISSENBOECK, M.; STEIN, E.; UNDT, G. Particle size of hydroxyapatite granules calcified from red algae affects the osteogenic potential of human mesenchymal stem cells in vitro. Cells Tissues Organs, v. 182, p. 79-86, 2006.

WERBER, K.D.; BRAUER, R.B.; WEISS, W. Osseous integration of bovine hydroxyapatite ceramic in metaphyseal bone defects of the distal radius. $\mathbf{J}$ Hand Surg, v. 25A, p. 833-841, 2000.

WHITE, R. A.; SHORS, E. C. Biomaterials aspects Interpore- $200^{\circledR}$ porous hydroxyapatite. Dent Clin Am, v. 30, p. 40-67, 1986.

WU, Y.C.; SHAW, S.Y.; LIN, H.R.; LEE, T.M.; YANG, C.Y. Bone tissue engineering evaluation based on rat calvaria stromal cells cultured on modified PLGA scaffolds. Biomaterials, v. 27, p. 896-904, 2006.

YAO, J.; HO, A.M. Bone Graft Substitutes in the Treatment of Distal Radius and Upper Limb Injuries. Oper Tech Orthop, v. 19, p. 77-87, 2009.

YONAMINE, Y. Effectable application of vascular endothelial growth factor to critical sized rat calvaria defects. Oral Surg Oral Med Oral Pathol Oral Radiol Endod, v. 109, p. 225-231, 2010.

YUNGER, E.M.; CHAPMAN, M.W. Morbidity at bone graft donor sites. Journal of Orthopedic Trauma, v. 3, p. 192-203, 1989.

ZADEH, M.B.; BAROUD, G.; BOHNER, M. Geometric analysis of porous bone substitutes using micro-computed tomography and fuzzy distance transform. Acta Biomaterialia, v. 6, p. 864-875, 2010.

ZOUHARY, K.J. Bone Graft Harvesting From Distant Sites: Concepts and Techniques. Oral Maxillofacial Surg Clin N Am, v. 22, p. 301-316, 2010. 


\section{ANEXO - Certificado de aprovação pela Comissão de Ética em experimentação animal}

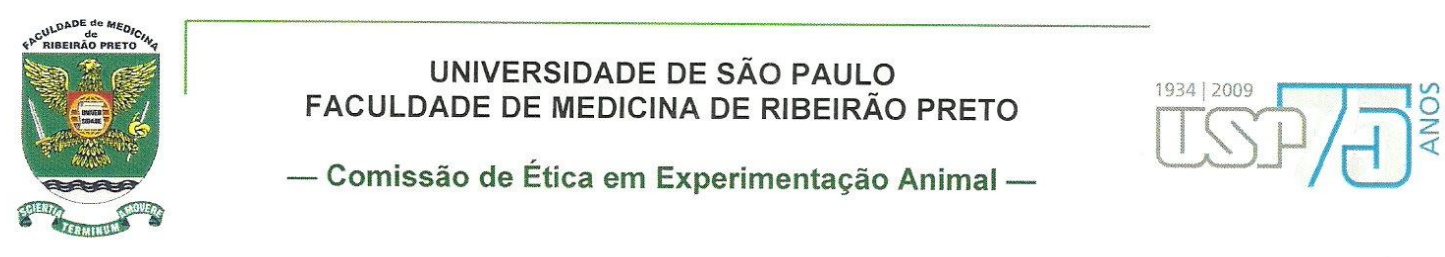

\section{CER TIFICADO}

Certificamos que o Protocolo para Uso de Animais em Experimentação $\mathbf{n}^{\circ}$ 028/2009, sobre o projeto intitulado "Avaliação da capacidade de regeneração óssea de compósitos a base de hidroxiapatita, colágeno e quitosana", sob a responsabilidade da Professora Doutora Ana Maria de Guzzi Plepis está de acordo com os Princípios Éticos na Experimentação Animal adotado pelo Colégio Brasileiro de Experimentação Animal (COBEA) e foi APROVADO em reunião de 30 de março de 2009.

(We certify that the protocol $n^{\circ} 028 / 2009$, about "Effect of hydroxyapatite, collagen and chitosan composites on bone regeneration in rat calvaria critical-size defects", agrees with the ETHICAL PRINCIPLES IN ANIMAL RESEARCH adopted by Brazilian College of Animal Experimentation (COBEA) and was approved $a$ in 03/30/2009 meeting.

Ribeirão Preto, 30 de março de 2009.

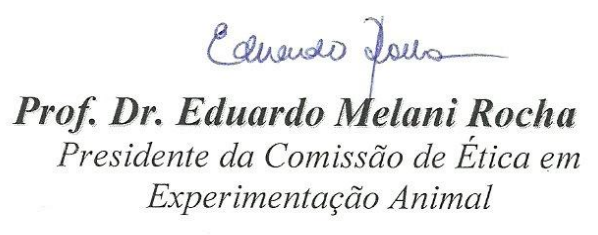

